\title{
¿DE TRANSICIONES Y PACHACUTIS?: UN PEQUEÑO DISEÑO EN VESTIMENTAS DE FIGURITAS DE CEREMONIAS DE ALTURA
}

\author{
OF TRANSITIONS AND PACHACUTIS?: A SMALL PATTERN IN FIGURINES \\ OF HIGH ALTITUDE CEREMONIES
}

VerónICA CerecedaA

En este trabajo nos adentramos en el complejo tema de las ceremonias de capacocha, realizadas en algunas alturas de los Andes durante la época inka. En ellas se ofrecían sacrificios humanos, especialmente de muchachas y niños de gran belleza, considerados perfectos. ${ }^{1} \mathrm{Al}$ interior de estos rituales sagrados, nos centramos solo en un aspecto: el diseño que va en las prendas femeninas, tejidas en miniatura, vistiendo a pequeñas estatuillas que forman parte de las ofrendas mortuorias. Dichos diseños atraen tanto por su carácter icónico, no siempre presente en el arte cusqueño, como por su reiteración obsesiva en estas ofrendas realizadas en las cumbres andinas.

Palabras clave: Enterratorios de altura, Estatuillas, Capacocha, Andes, Diseños, Tejidos.

In this paper, we explore the complex subject of Capacocha ceremonies held in some mountain tops of the Andes during Incan times, where human sacrifices, especially of girls and boys of great beauty and deemed perfect, were done. We have focused on one aspect of these sacred rituals, namely, the pattern on the miniature woven feminine garments dressing the figurines that are part of the mortuary offerings. These patterns stand out not only because of their iconic nature, not always present in the Cusco art, but also because of their obsessive repetition in these offerings made in the Andean peaks.

Keywords: High-rise burial ground, Figurine, Capacocha, Andes, Textiles.

\section{EL CONTEXTO DE LA CEREMONIA}

Utilizamos el término capacocha que se ha ido haciendo familiar en los trabajos actuales, aunque otros estudiosos se refieren a estos rituales como capac hucha. Ambas denominaciones aparecen en diferentes crónicas. Este segundo nombre ha sido traducido como "gran pecado o culpa”, pero Taylor (¿Tomás? 2008: 16) aclara que, además de "falta" o "pecado", hucha "mantiene su sentido de obligación ritual", agregando que "el capac hucha corresponde a la realización de una obligación ritual de máxima importancia y esplendor" (¿Tomás? 2008: 170).

En los últimos años han surgido trabajos muy detallados e importantes de arqueólogos e historiadores sobre estas celebraciones. ${ }^{2}$ Rescatando solo algunas referencias a estos estudios, quisiéramos recordar el enorme esfuerzo humano y económico que cada capacocha implicaba: trabajo especializado de la mano de obra para la elaboración de delicadas ofrendas necesarias para estas ceremonias; largas caminatas a pie, de la caravana que partía desde el Cusco para llegar hasta lugares muy apartados del Tawantinsuyu -más de 1550 $\mathrm{km}$, por ejemplo, para alcanzar las cimas del volcán Llullaillaco, una de las principales capacocha conocidas-, llevando niños y transportando bienes para ofrecer a las deidades de las montañas; difíciles ascensos a heladas

A Verónica Cereceda, Asur, Antropólogos del Sur Andino, Sucre. E-mail: veronicacereceda@gmail.com 

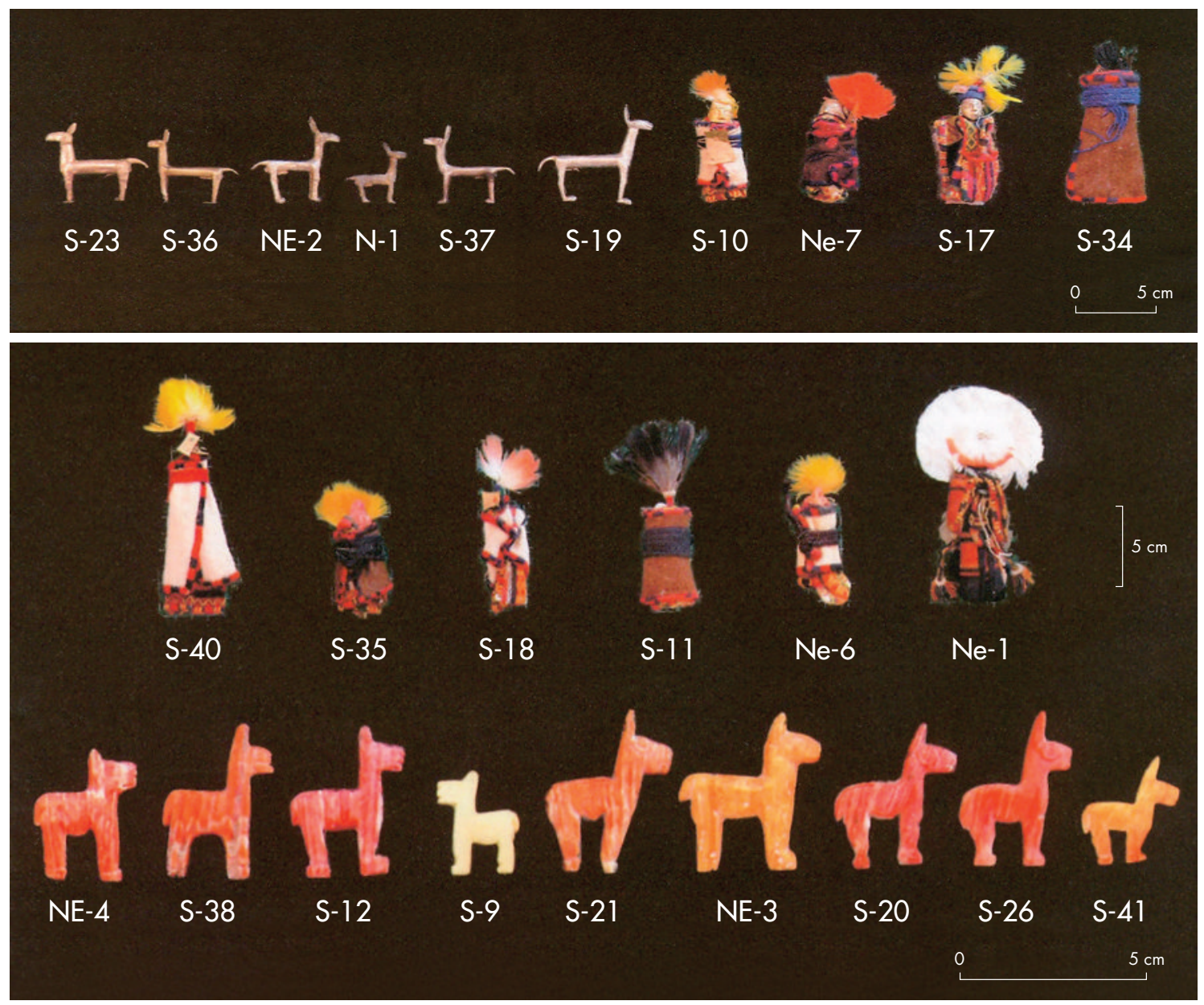

Figura 1. Figuritas zoomorfas y antropomorfas que acompañan enterratorios de altura en el Santuario del volcán Llullaillaco, Noroeste de Argentina. (Fotografía: MAAM, en Mignone 2009: 63). Figure 1. Zoomorphic and anthropomorphic figurines accompanying high-altitude burials in the Llullaillaco Volcano Sanctuary, Northwestern Argentina. (Photograph: MAAM, in Mignone 2009: 63).

y escarpadas alturas, a veces de más de $6000 \mathrm{msnm}$, donde se realizaban las ceremonias, más la ejecución de sacrificios humanos.

Las celebraciones perseguían objetivos de gran trascendencia, tales como afianzar alianzas con las autoridades de nuevos territorios conquistados, legitimar la dominación integrando las lejanas poblaciones al panteón cuzqueño, promover la circulación de mitmaq y bienes, entre muchos otros. En este contexto, la dimensión de nuestro objeto de estudio son las imágenes, tan angostas como un dedo meñique, logradas tejiendo hilos muy finos de vellón de camélidos (con la técnica del pallay, en quechua $)^{3}$ en las vestimentas de las estatuitas depositadas entre las ofrendas, para sugerir luego una de sus posibles lecturas.
¿Cuál pudo ser el papel que desempeñaron estos diseños en esos grandiosos rituales, a pesar de su pequeño tamaño?

\section{Las estatuillas}

Muy cerca de los cuerpos enterrados en estos santuarios han sido encontradas figuritas en formato menor que parecen acompañarlos. Las hay de dos tipos: representaciones de camélidos y representaciones antropomorfas. Entre estas últimas, se distinguen masculinas y femeninas (fig. 1).

Cuando las figuritas antropomorfas están desnudas, ${ }^{4}$ solo tres materiales son visibles como conformando sus cuerpos: oro, plata -en diversas alianzas- y Spondylus 

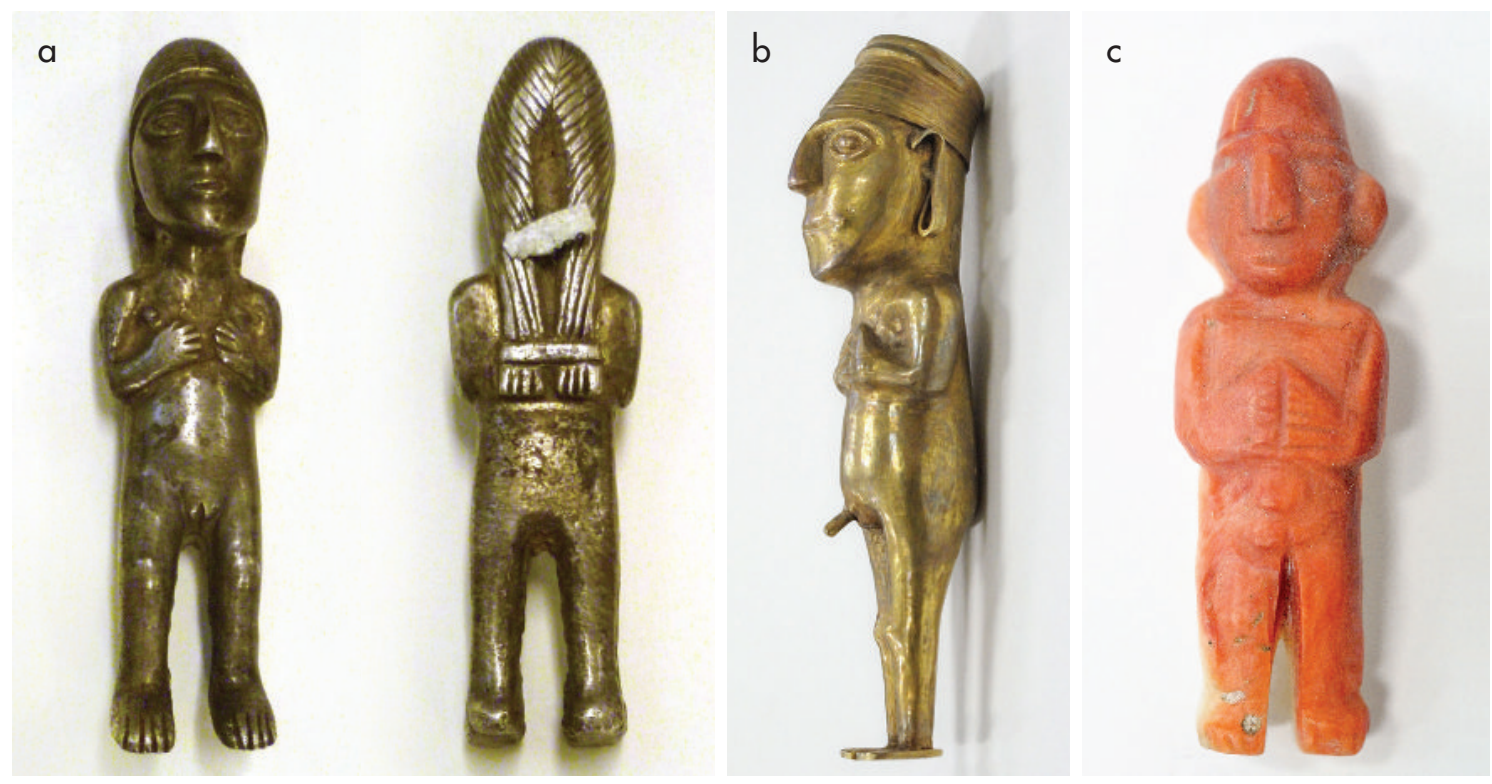

Figura 2. Tres materiales: a) plata, anverso y reverso de figurita de plata. Es posible ver el peinado en múltiples trenzas o mechones, formando dos haces de cabello, característico de todas las estatuillas femeninas. Museo Arqueológico de La Serena, en adelante, MALs. (Fotografía: gentileza del MCHAP); b) oro (figurita masculina, con el sexo destacado. MAAM); c) Spondylus (figurita masculina, no tan detallada como las metálicas. MAAM). Figure 2. Three materials: a) silver, front and back of a silver figurine. The multiple braid or multilock hairstyle, forming two hair bundles, typical of all female figurines, can be observed. Museo Arqueológico de La Serena, hereinafter, MALS. (Photograph: courtesy of MCHAP); $b$ ) gold (male figurine with outlined genitals. MAAM); $c$ ) Spondylus (male figurine, not as detailed as the metallic ones. MAAM).

(concha marina). ${ }^{5}$ Los tamaños de las que conocemos hasta hoy oscilan entre $2,50 \mathrm{~cm}$ y $14 \mathrm{~cm}$ de altura, salvo una de $27 \mathrm{~cm}$ que se encuentra en el Museo Arqueológico de Alta Montaña (en adelante MAAM), en Salta, que es una excepción en este corpus, ${ }^{6}$ y sus atuendos son muy delicados.

Las tres materias primas no parecen tener una relación con el sexo de las estatuitas: las hay femeninas tanto en plata, oro como Spondylus, e igual cosa sucede con las masculinas. Las figuritas femeninas -de las cuales analizaremos luego sus vestimentas- tienen rasgos que las hacen equivalentes, sean cuales sean los materiales con que están confeccionadas: posición rígida con las piernas levemente entreabiertas, manos posadas sin movimiento sobre el pecho, y especialmente, un mismo peinado para todas, en múltiples mechones torcidos o trenzas, separados en dos por una raya en el centro de la cabeza y sujetos hacia atrás por una traba, es decir, expresando ya, en la disposición de la cabellera, una determinada pertenencia cultural que les es común.

De los cuerpos desnudos de las estatuitas surgen así tres consideraciones que, más adelante, no podremos olvidar: a) se trata de un mismo personaje esculpido; b) con tres variantes: oro, plata, Spondylus (en el caso de estas pequeñas miniaturas estos materiales no parecen constituir una jerarquía de valores) y; c) una alusión a una identidad (un mismo peinado). ${ }^{?}$

\section{Las vestimentas de las figuritas femeninas}

Varias de estas pequeñas estatuillas antropomorfas que han sido desenterradas de las capacochas, llevan aún los trajes con las que las vistieron hace más de quinientos años, aunque en algunos casos sus vestimentas se han dañado con el paso del tiempo. Hay también hallazgos de sus diminutas ropas sin una figurita a la que pudieron pertenecer o que, tal vez, nunca pertenecieron a un cuerpo preciso. Es ese conjunto de vestimentas femeninas el que estamos considerando para intentar una lectura del diseño que las unifica.

Los atuendos son muy delicados. Además de las emociones que nos despiertan la maestría y la belleza de sus trajes $\tan$ primorosamente confeccionados, esos 


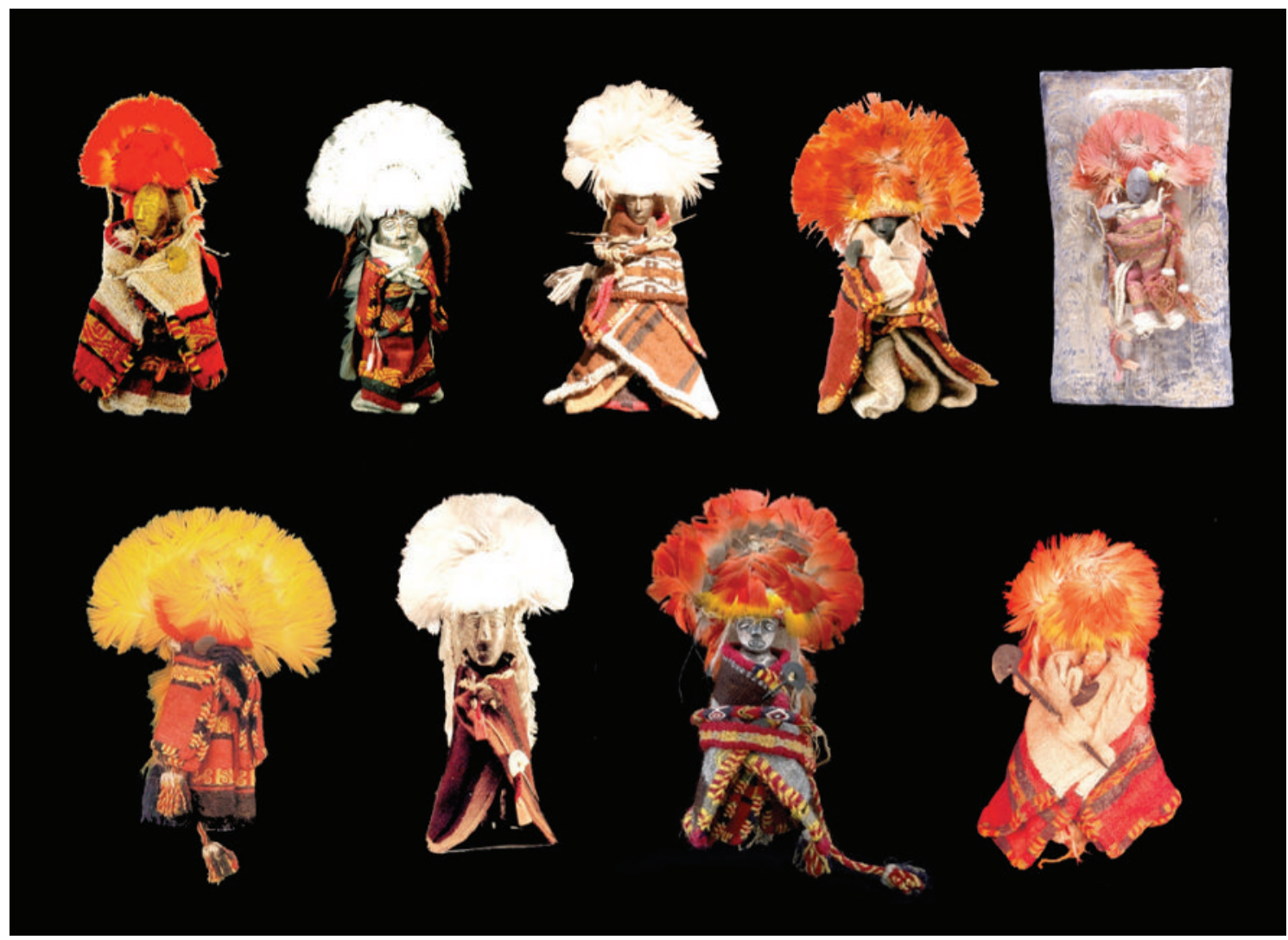

Figura 3. Diferentes vestimentas femeninas procedentes de diversos enterratorios. Figure 3. Several female garments from various burials.

pequeños vestuarios poseen una multitud de sistemas significantes que nos aportan informaciones sobre la sociedad incaica más tardía, en sus avances de conquistas en territorios de lo que hoy son el norte y sur del Perú, el norte argentino y norte de Chile. Por esta vez, tomamos como tema solo los diseños reiterativos que llevan las vestimentas femeninas, salvo algunas referencias puntuales a las también diminutas prendas masculinas, en algunos rasgos que coinciden. Las angostas decoraciones tejidas nos plantean tantos problemas de interpretación que ya de por sí son densas y difíciles de abordar.8

Cuando está completo, el traje está formado por cuatro piezas principales. Un aqsu (en quechua; anaku o urku, en aymara), túnica femenina que, en el caso de estas figuras, corresponde a un rectángulo tejido que va envuelto en torno al cuerpo de la estatuita, sujeto a los hombros por dos tupus (prendedores de plata); ${ }^{9}$ un chumpi (faja que ajusta el aqsu a la cintura); una lliklla (manta sobrepuesta), prendida junto a la altura del cuello con otro tupu; y un atuendo cefálico compuesto por una impresionante cofia de plumas, semicircular, que forma una suerte de abanico, cubriendo la cabeza y cayendo por la espalda, como puede observarse en la figura $3 .{ }^{10}$

Las tres primeras prendas corresponden a la vestimenta típica de la época inkaica. Para el atuendo de plumas -tal como aparece en las cabezas de las figuritas femeninas de altura- no hemos encontrado una referencia bibliográfica precisa ni ahora ni en textos que se refieran a usos en tiempos del Tawantinsuyu, aunque hubiese sido como un adorno cefálico en algún ritual. ${ }^{11}$ Las otras prendas tejidas nos son familiares en diferentes pinturas o dibujos del traje femenino cuzqueño e incluso se siguen utilizando hoy en algunas regiones de Perú y Bolivia, que conservan tradiciones originarias.

Además de las cuatro prendas mencionadas, los vestuarios están compuestos por algunos objetos: Cordones y trenzados. Además, cuelgan también del cuello de estas miniaturas adornos hechos de concha marina (Spondylus) en forma trapezoidal. Todo ello les confiere un aspecto abigarrado que sugiere la necesidad de una 


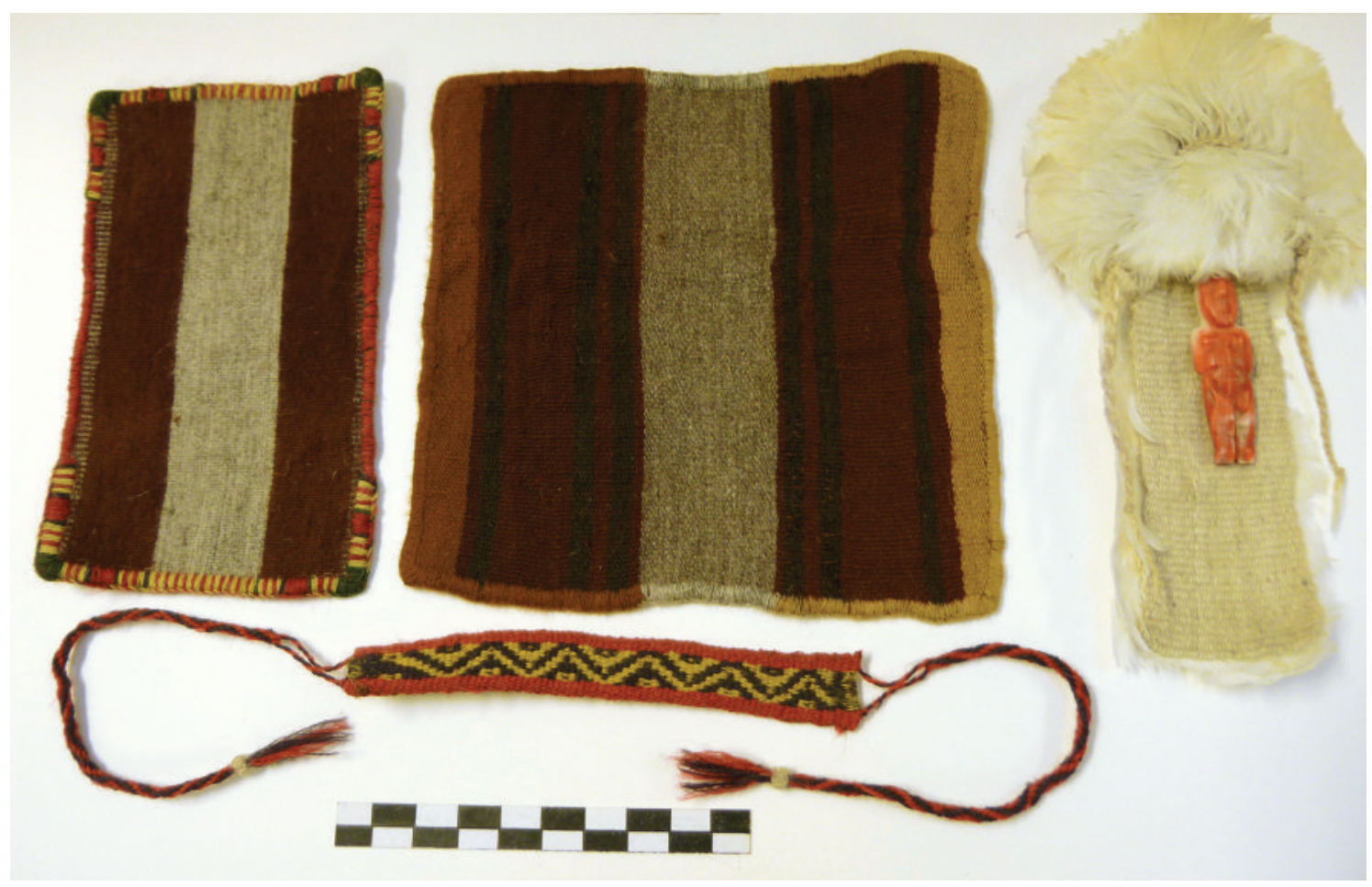

Figura 4. Figurita con toda su vestimenta, en este caso, solo en tonos naturales: a) lliklla (manta): la reconocemos porque lleva tres bandas, dos cafés y una blanca grisácea; b) el aqsu (paño que envuelve el cuerpo como una túnica, siempre de cinco bandas); c) figurita con su atuendo cefálico; d) chumpi (faja). cerro Las Tórtolas, MALs. (Fotografía: MCHAP). Nótese la desproporción entre el cuerpo de Spondylus y las prendas tejidas que le pertenecen. ${ }^{12}$ Figure 4. Figurine with all its clothes, in this case, only in natural tones: a) lliklla (blanket): we can recognize it because it has three stripes (two are brown and one is grayish white); $b$ ) aqsu (cloth the body like a tunic, always with five stripes); c) figurine with its cephalic garment; d) chumpi (girdle). Las Tórtolas Hill, MALs. (Photograph: MCHAP). Note the disproportion between the Spondylus's body and its woven garments.

intensa comunicación de significados y emociones con un fin ritual. Percibimos, en la siguiente figura (fig. 6), la cabecita de la figurita femenina en oro, entre cordones y otros adornos.

Cuando observamos las vestimentas femeninas de estas pequeñas estatuitas de altura, encontramos varios rasgos que nos inquietan.

\section{PRIMERA INQUIETUD: LA CLASIFICACIÓN OBJETIVA DE LOS TRAJES EN DOS GRUPOS QUE LOS DIFERENCIAN}

\section{Una taxonomía dual}

a) Entre los trajes hay unos que no llevan dibujos ni en su aqsu ni en su lliklla (salvo en el chumpi, faja), ni tonos teñidos, solo naturales (aqsu y lliklla en la figura 4, figurita vestida en figura 7d). En algunos casos los angostos bordados de los festones (como se observan en la lliklla de la figura 4) están realizados con tonos brillantes, pero en este primer tipo -que denominamos "A"-, dichos tonos no se disponen iluminando espacios más amplios y llanos.

b) El grupo que denominamos B, está compuesto por trajes que llevan colores obtenidos por tintes y dibujos (pallay). Son los más numerosos y forman parte de nuestro tema (figs. 5 y $7 \mathrm{a}, \mathrm{b}$ y c).

Las pequeñas estatuitas femeninas pueden llevar estos dos tipos de vestuario sin que correspondan a las materias primas de sus cuerpos.

En un mismo enterratorio, por ejemplo, en Llullaillaco, se han encontrado vestimentas femeninas de las estatuillas de estos dos tipos: unas sin dibujos y con tonos naturales en la lliklla como en el aqsu, y otras 


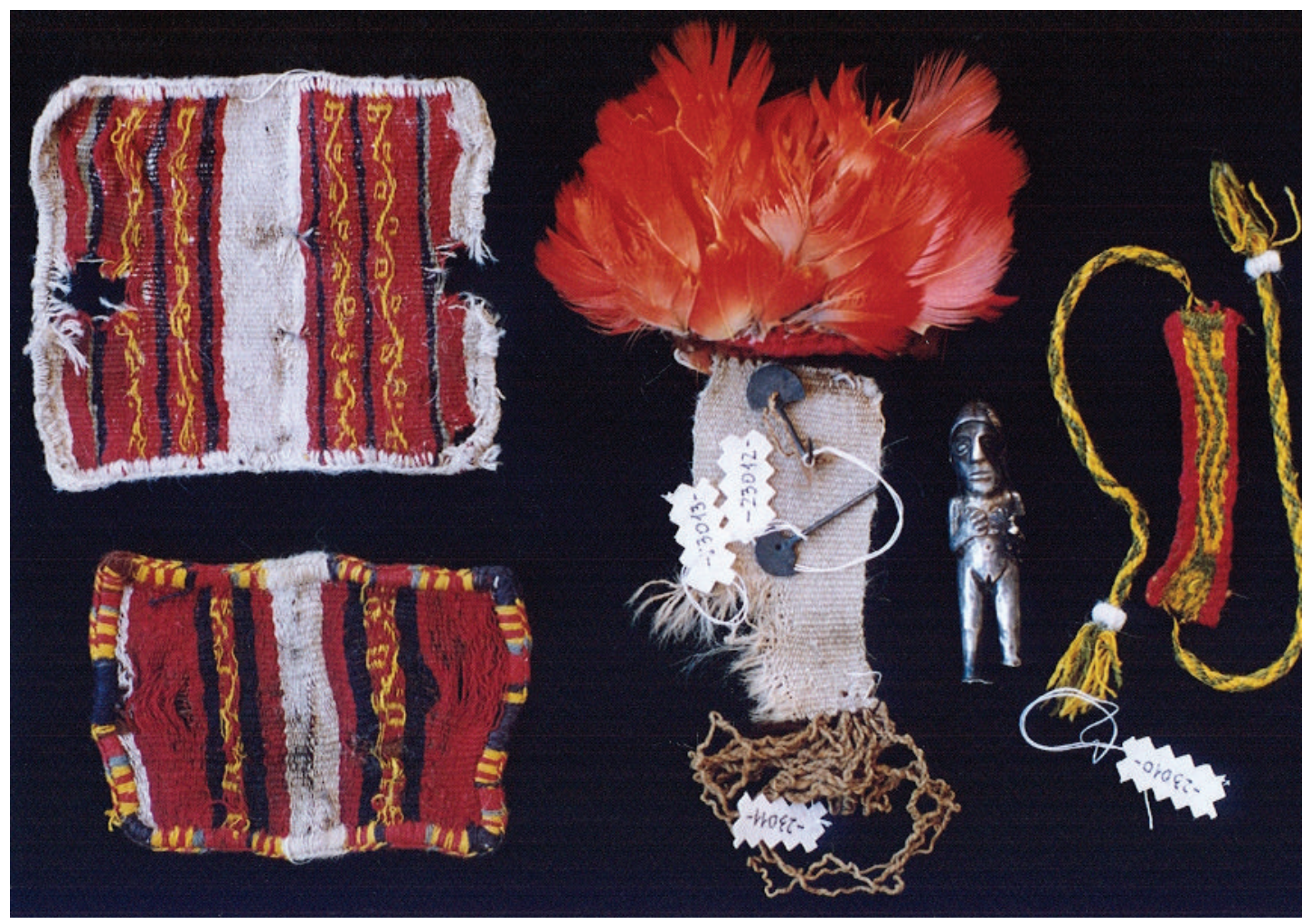

Figura 5. Mathías Reibistch rescató otro conjunto completo en el cerro Gallán, Argentina, con prendas que llevan tonos vivos. El tamaño de la figura es más proporcional a su vestimenta que en otras estatuillas vestidas, y esta se doblaba en dos para coincidir con el cuerpo. (Pieza 23007, Museo Etnográfico Juan B. Ambrosetti, Buenos Aires. Fotografía: I. Iriarte y S. Renard, en Hoces de la Guardia $\&$ Rojas 2016). Figure 5. Mathías Reibistch rescued another entire set with bright color garments in Cerro Gallán, Argentina. The size of the figurine is more proportional to its clothing than other dressed figurines, and this one folded in two to match the body. (Piece 23007, Museo Etnográfico Juan B. Ambrosetti, Buenos Aires). (Photograph: I. Iriarte and S. Renard. in Hoces de la Guardia \& Rojas 2016).

con tonos brillantes obtenidos por tintes y dibujos, en ambas prendas. ${ }^{13}$

El grupo que hemos llamado B se subdivide a su vez en varias posibilidades que, con los datos actuales, no podemos considerar como etnocategorías. Para distinguir bien estas diferencias entre los vestuarios que llevan dibujos y tonos teñidos, designaremos como "banda" los espacios más o menos amplios y monocromos, que van, únicamente en los aqsus -no en las mantas-al comienzo y al final de la túnica. Llamaremos "pampa" al también amplio y monocromo espacio central, que comparten aqsu y lliklla (usando esta denominación de pampa, compartida entre quechua y aymara y vigente hoy). Por último, usaremos el término "franja" para los espacios que contienen pallay, es decir, guardas con dibujos (fig. 7). Los pallay pueden ser uno, dos o tres, en una misma franja. Es interesante notar que las franjas en las cuales se insertan estos diseños son siempre rojas, reiteración

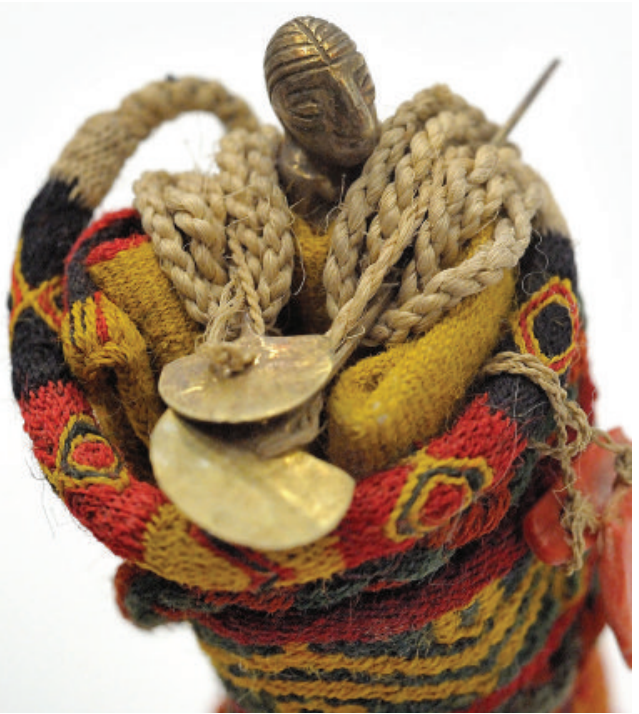

Figura 6. LL-99-058 MAAM. Figure 6. LL-99-058 MAAM. 


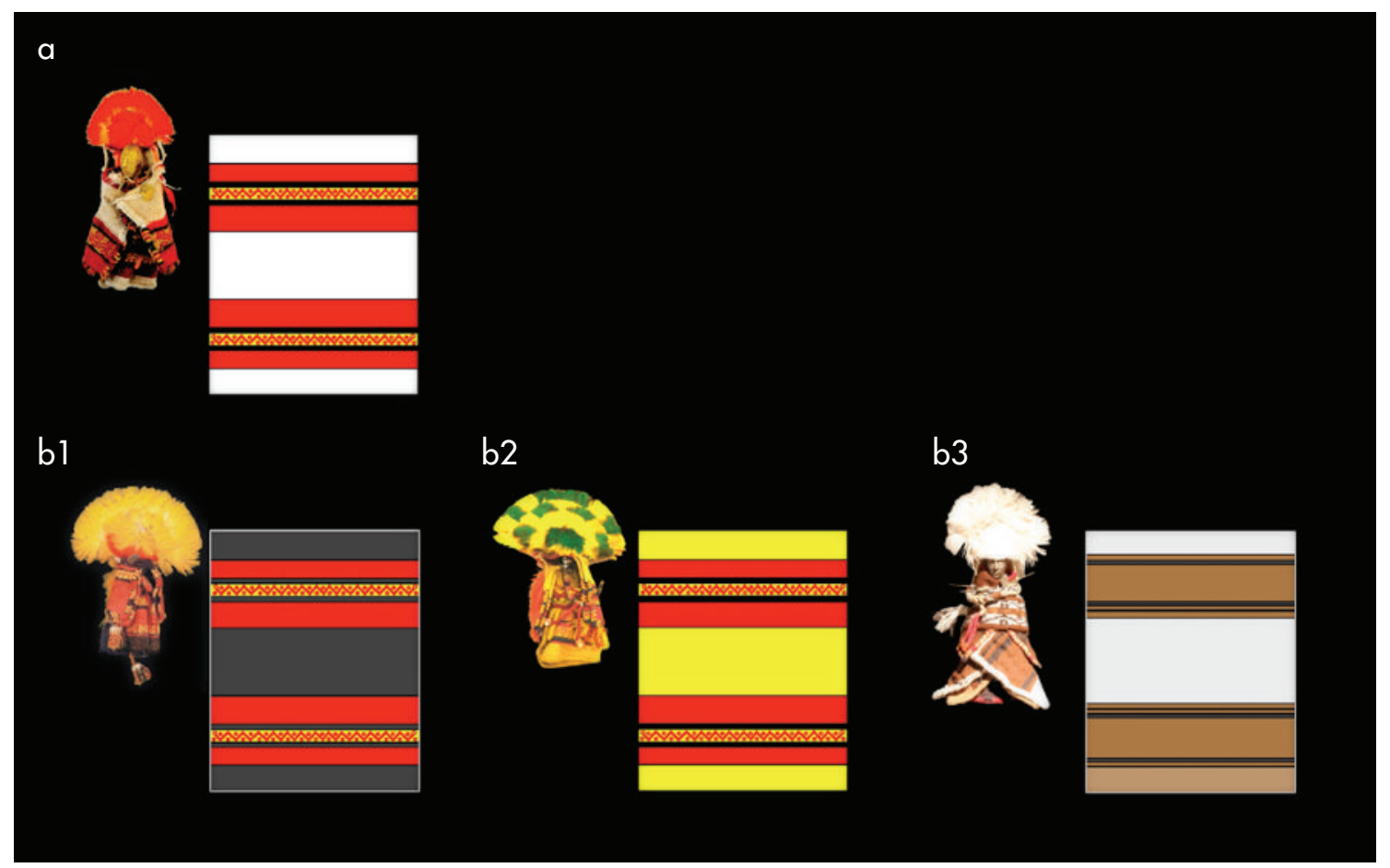

Figura 7. Aqsu, prenda femenina que cubre directamente el cuerpo: a) con colores naturales (MALs); b1) con colores teñidos Llullaillaco (LL-99-054 MAAM; b2) LL-99 078 MAAM; b3) LL-99-015. (Dibujo: P. Cruz). Figure 7. Aqsu, feminine garment that covers the body directly: a) with natural colors (MALS); b1) with Llullaillaco dyed colors (LL-99-054 MAAM; b2) LL-99078 MAAM; b3) LL-99-015. (Drawing: P. Cruz).

común a este tipo de vestuario y, por lo tanto, ese tono no distingue a las vestimentas entre sí al interior del grupo B. Las diferencias se deben al color de los espacios monocromos más amplios. En estas prendas menores B, conocemos hasta ahora varias posibilidades cromáticas:

- bandas y pampa blancas (fig. 7a).

- bandas y pampa negras (fig. 7b).

- bandas y pampa amarillas (fig. 7c). Ejemplos todos presentes en Llullaillaco.

- bandas y pampa verdes (en un aqsu publicado por A. Rowe 1977: 17, fig. 15). Solo una mención a este tono, ya que la figura no va en colores. ${ }^{14}$

Lo que reúne a todas estas prendas con diferencias cromáticas en sus espacios llanos es la presencia común a todas de dibujos y tonos teñidos, que hemos calificado como tipo B. La coloración de los espacios llanos no corresponde tampoco al material de las figuritas.

En la figura 8 es posible observar la vestimenta completa de una misma estatuilla y distinguir sus diferentes espacios. En la parte superior vemos la lliklla (manta) doblada en dos. Abajo, su aqsu (túnica) y su chumpi (faja), que lo ajusta al cuerpo. Se aprecia, como ya señalábamos, que en la lliklla los espacios son siempre tres: uno arriba y otro abajo conteniendo los dibujos (en el caso de la prenda de la figura 8 , franjas con tres pallay) y un espacio central, llano, su pampa, que en esta lliklla es amarilla. La lliklla como el aqsu que la acompaña, fueron dispuestos por quien las vistió hace cientos de años, doblados sobre sí mismos. No es visible en la imagen su repetición simétrica hacia el otro lado.

El aqsu (fig. 8), en cambio, está siempre estructurado en cinco espacios, lo que permite reconocerlo como tal: una banda arriba y otra abajo, sectores monocromos al comienzo y al final. Las bandas son igualmente amarillas. Más arriba se observan las franjas que contienen los motivos de los pallay, tanto en la parte superior como inferior del vestido (del que observamos solamente la mitad). Al centro se ubica, como siempre, la pampa; se observa su comienzo en amarillo, ocultado en parte por la faja.

Extendiendo estas prendas, tendríamos para el aqsu: - Banda plana en el borde de la prenda. 
- Franja roja, que en este caso lleva dos guardas con dibujos.

- Pampa amarilla, que va casi cubierta por la faja o chumpi.

Y dando la vuelta lo mismo, pero a la inversa. La prenda está doblada.

No existe una correlación entre el color de las pampas y el material con que se elaboró la figurita. Pampas amarillas pueden ir igualmente en figuritas de oro o plata. ${ }^{15}$

En la figura 9 se pueden observar tanto los cuerpos de plata y de Spondylus que van vestidos, igualmente, sin diseño ni colores vivos. Lo mismo sucede con figuritas que llevan tonos teñidos, pero diferentes materias primas en sus estatuillas.

¿A qué corresponden las variantes en el tono de las pampas de las llikllas o bandas y pampas de los aqsus que llevan diseño: negras, blancas, amarillas o verdes?, ¿son colores aleatorios o normados, aludiendo con ello a distintos significados?, ¿y a qué se debe esta diferencia fundamental de las vestimentas: sin dibujos, sin uso de tintorería/con diseño y tonos teñidos? La existencia de esos dos tipos de vestimentas plantea ya un primer problema, pero, además, abre otro dilema: la utilización de tres materias primas (oro, plata, Spondylus) para definir los cuerpos.

Entrando brevemente en el tema de visiones ontológicas propias de los Andes que se han ido planteando más recientemente, percibimos las estatuitas elaboradas por artesanos especialistas como ya dotadas en sí mismas de una personalidad espiritual y de un poder agencial. ${ }^{16}$ Para Allen, en épocas precolombinas "todo el universo material estaba potencialmente vivo e imbuido de espíritu" (2016: 24).

Destacamos la expresión 'potencialmente' y creemos que, en las estatuitas entendidas como objetos sagrados con misiones concretas a realizar en las altas cumbres de los Andes, elaborados necesariamente entre rituales y las cuidadosas observaciones de sabios (amautas) o sacerdotes andinos, esta potencialidad debió estar necesariamente activa. Habrían surgido dotadas ya de un tipo especial de kausaq, como la denomina Allen (2016), de kausay, "vivir" en quechua. En este contexto, el vestuario es una sobre-determinación o determinación secundaria que se superpone sobre este ser, potencialmente vivo, ya desde su desnudez. Y así, la primera clasificación en tres materias primas se vuelve ambigua y compleja.

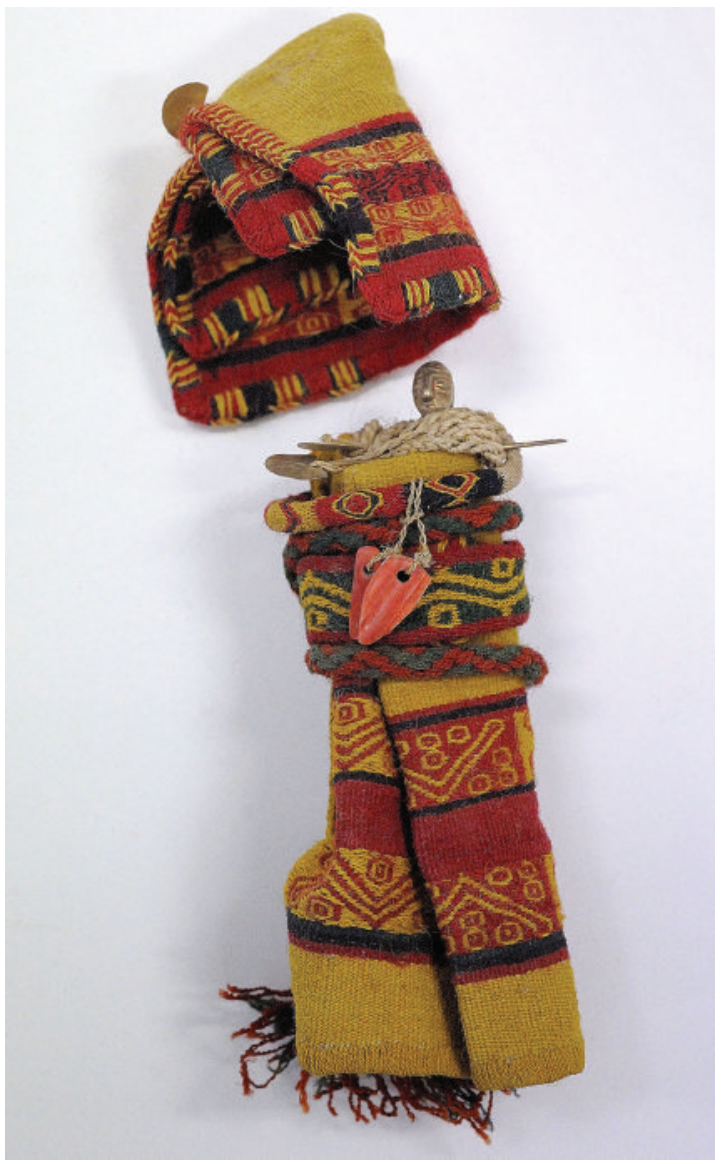

Figura 8. MAAM, LL-99-058. Figure 8. MAAM, LL-99-058.

Los cromatismos de las ropas no respetan la distinción tripartita entre el oro, la plata y el Spondyus (fig. 9). ¿Cómo entenderlo?

Tres materias primas, pero dos primeras posibilidades en las prendas: natural sin pallay o teñidas con dibujos. Y, luego, si son de este último tipo, cuatro o quizás más variables. ¿De qué modo las vestimentas, así dispuestas, alteran la personalidad de la que ya estaban dotadas las estatuillas? Los colores cumplen dos funciones: las distinguen entre sí -las que llevan pallay, las que no lo llevan- $y$, al mismo tiempo, las agrupan con otras que, siendo sus cuerpos de distintos materiales, coinciden en alguna de estas dos diferencias. Una categorización que no es común observar en otras materialidades inkaicas: tres entidades a las que se les sobreponen solamente dos alternativas.

Es posible que las figuritas fueran consideradas como un conjunto de variantes, cuya especificidad 

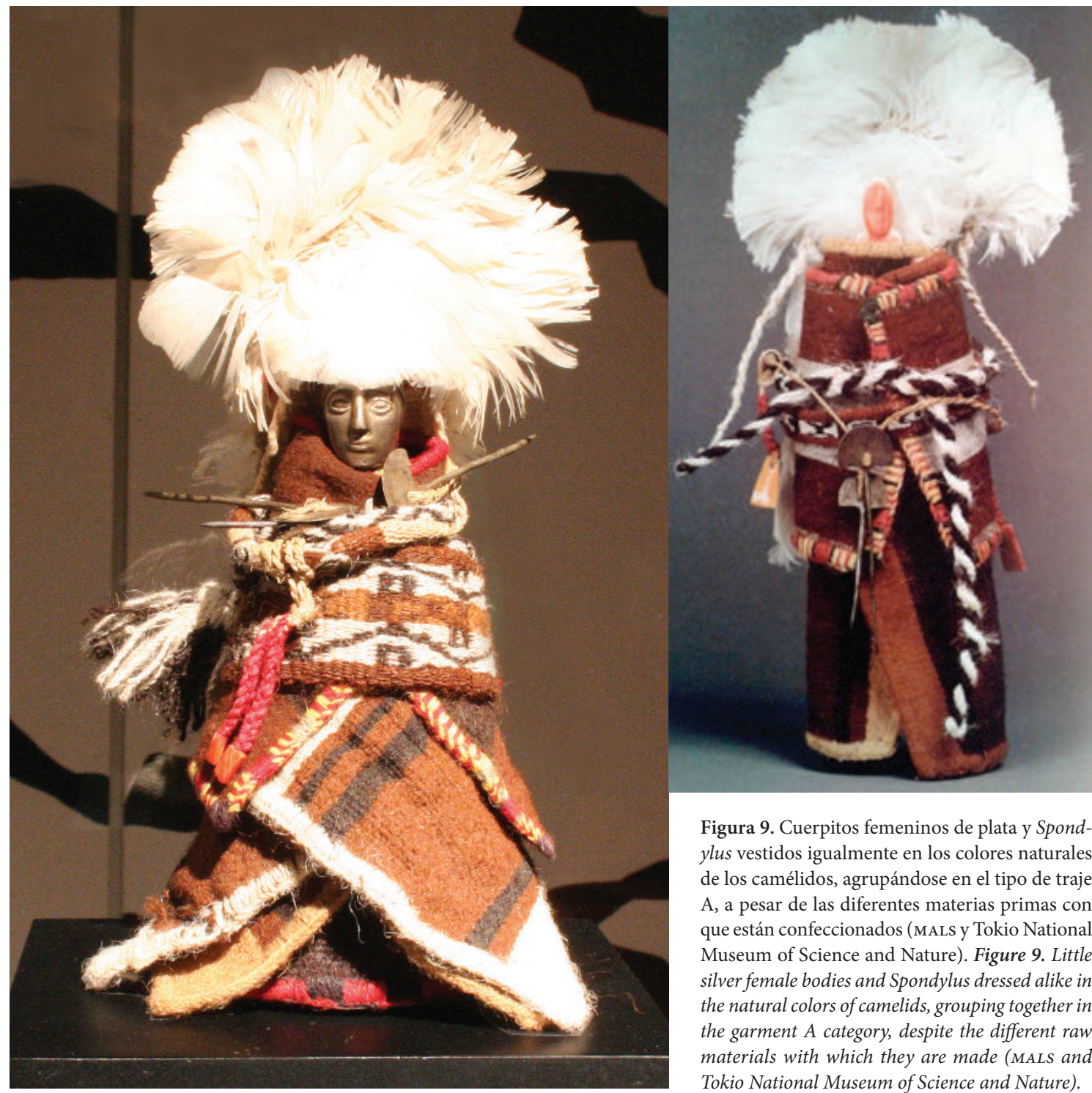

Figura 9. Cuerpitos femeninos de plata y Spondylus vestidos igualmente en los colores naturales de los camélidos, agrupándose en el tipo de traje A, a pesar de las diferentes materias primas con que están confeccionados (MALs y Tokio National Museum of Science and Nature). Figure 9. Little silver female bodies and Spondylus dressed alike in the natural colors of camelids, grouping together in the garment A category, despite the different raw materials with which they are made (MALS and Tokio National Museum of Science and Nature).

reside, justamente, en ser una pluralidad de personajes con sus composiciones individuales (relación cuerpos $\mathrm{y}$ vestimentas, aunque, a veces algunos ejemplares coinciden entre ellos). El escaso número de estatuitas en miniatura rescatadas de algunas capacochas ya excavadas por arqueólogos, sugiere que podrían representar a todo el conjunto. Según Narváez et al. (1995), solo han sido encontradas tres estatuitas femeninas en Túcume -dos de plata, una con vestimenta sin pallay, la otra con diseño- y una de Spondylus, cuyos trajes no han sido descritos aún. Lo mismo ocurre en Ambato, excavado por Reinhard y Chávez: solo tres estatuitas femeninas
(Conklin 1996). ¿Fueron seleccionadas estas figuritas en estas ocasiones por los diferentes tonos de sus espacios llanos, destinados a diferentes matices del ritual? Todas son de confección cuzqueña, de modo que difícilmente hubiesen representado en estos diferentes colores a las regiones donde iban a ser inmoladas. En cambio, en Llullaillaco, también excavado científicamente (Reinhard \& Ceruti 2010), una gran cantidad (12 figuritas femeninas y 11 masculinas) estaría dando cuenta de esa existencia plural.

Las vestimentas en miniatura llevan también múltiples diferencias entre ellas en relación con el colorido de 


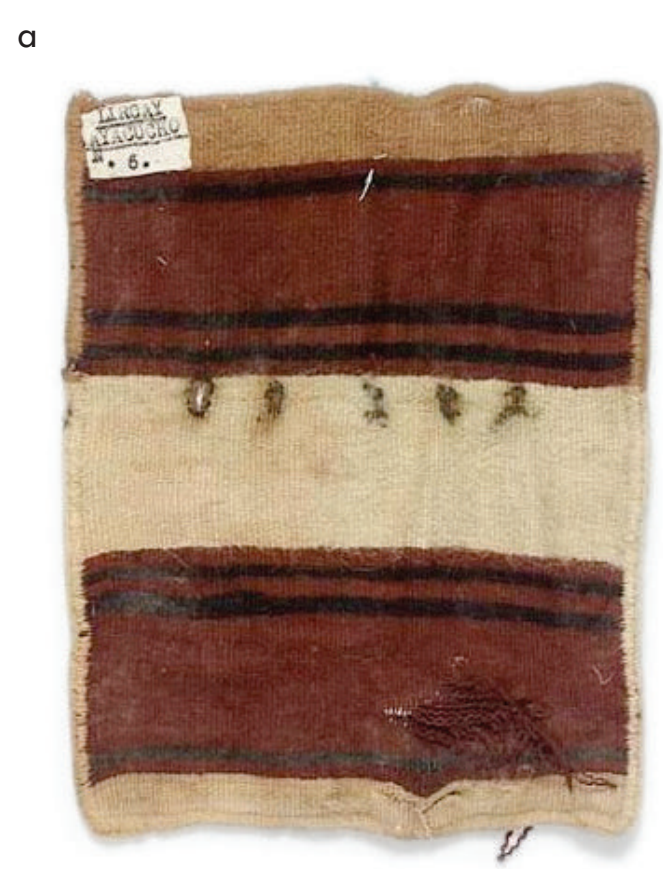

\section{b}

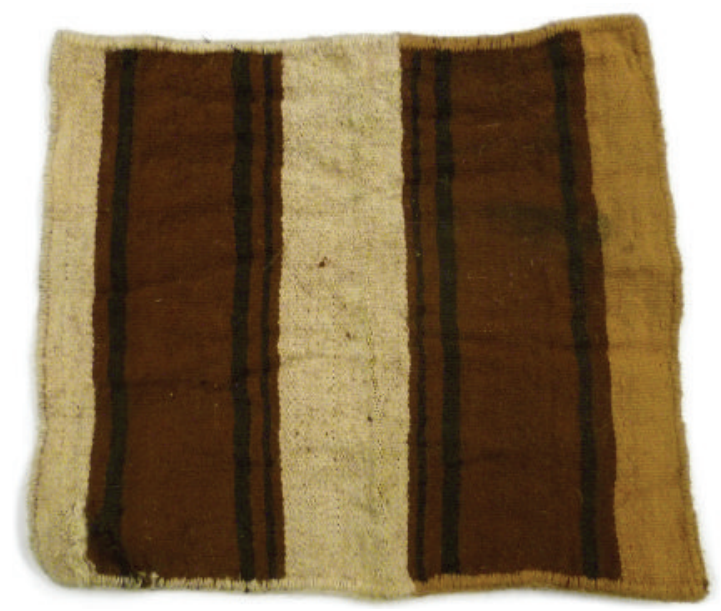

Figura 10: a) aqsu proveniente de Lircay (Museo Nacional de Arqueología, Antropología e Historia, MNAAH, Perú. Fotografía: gentileza de H. Horta); b) aqsu excavado en el volcán Copiapó, Chile (Fotografía: gentileza MCHAP). Figure 10: a) aqsu from Lircay (Museo Nacional of Arqueología, Antropología e Historia, MNAAH, Peru, courtesy of H. Horta); b) aqsu found in the Copiapó volcano, Chile (Photograph courtesy of MCHAP).

las plumas que las completan con sus atuendos cefálicos. El vínculo posible entre los variables tonos del plumaje y los de las prendas de vestuario no sería fácil de establecer para completar esta tipología. En muchos casos, esas coronas no se han encontrado junto a los cuerpos y contamos con numerosas prendas aisladas que no corresponden a una vestimenta específica y están, por lo tanto, sin plumajes.

\section{SEGUNDA INQUIETUD: AUNQUE LOS ENTERRATORIOS ESTÉN MUY ALEJADOS ENTRE SÍ, ES POSIBLE ENCONTRAR UNA GRAN SEMEJANZA EN ALGUNOS AQSU O LLIKLLA ALLII EXCAVADOS}

En la imagen siguiente (fig.10) es posible observar dos aqsus desenterrados, uno en Lircay (Perú) y otro en el volcán Copiapó (Chile, Norte Chico), correspondiendo al tipo A sin dibujos. Son muy parecidos y comparten una misma propuesta sensible. Al interior de las bandas cafés se perciben listas negras que apenas se notan (un detalle casi invisible), coincidiendo en los dos aqsus, así como la igual disposición asimétrica del tono de las bandas exteriores, más claras arriba, más oscuras abajo. Dicha asimetría distingue las bandas de los aqsus con dibujos, sobre los que volveremos más adelante. Estamos frente a un modelo o matriz. ¿Cómo se conservó por largos períodos, quizás decenios? ${ }^{17}$

En la figura 11 vemos una figurita enterrada mucho más lejos aún, en el volcán Llullaillaco (Noroeste de Argentina), la que lleva también listas negras sobre la banda café. Esta semejanza sugiere que estos aqsus no expresan una procedencia local, sino que serían de manufactura cuzqueña, como todas las otras prendas de estos pequeños vestuarios, tal como lo plantea Vitry (2008) para las propias estatuillas antropomorfas. Es difícil encontrar en estas prendas femeninas rasgos que manifiesten una identidad y un pensamiento de los grupos no inkas que participaban, también como contraparte, en estos rituales de cumbres y que adoraban estas montañas antes de la llegada de los cuzqueños. ${ }^{18}$ 


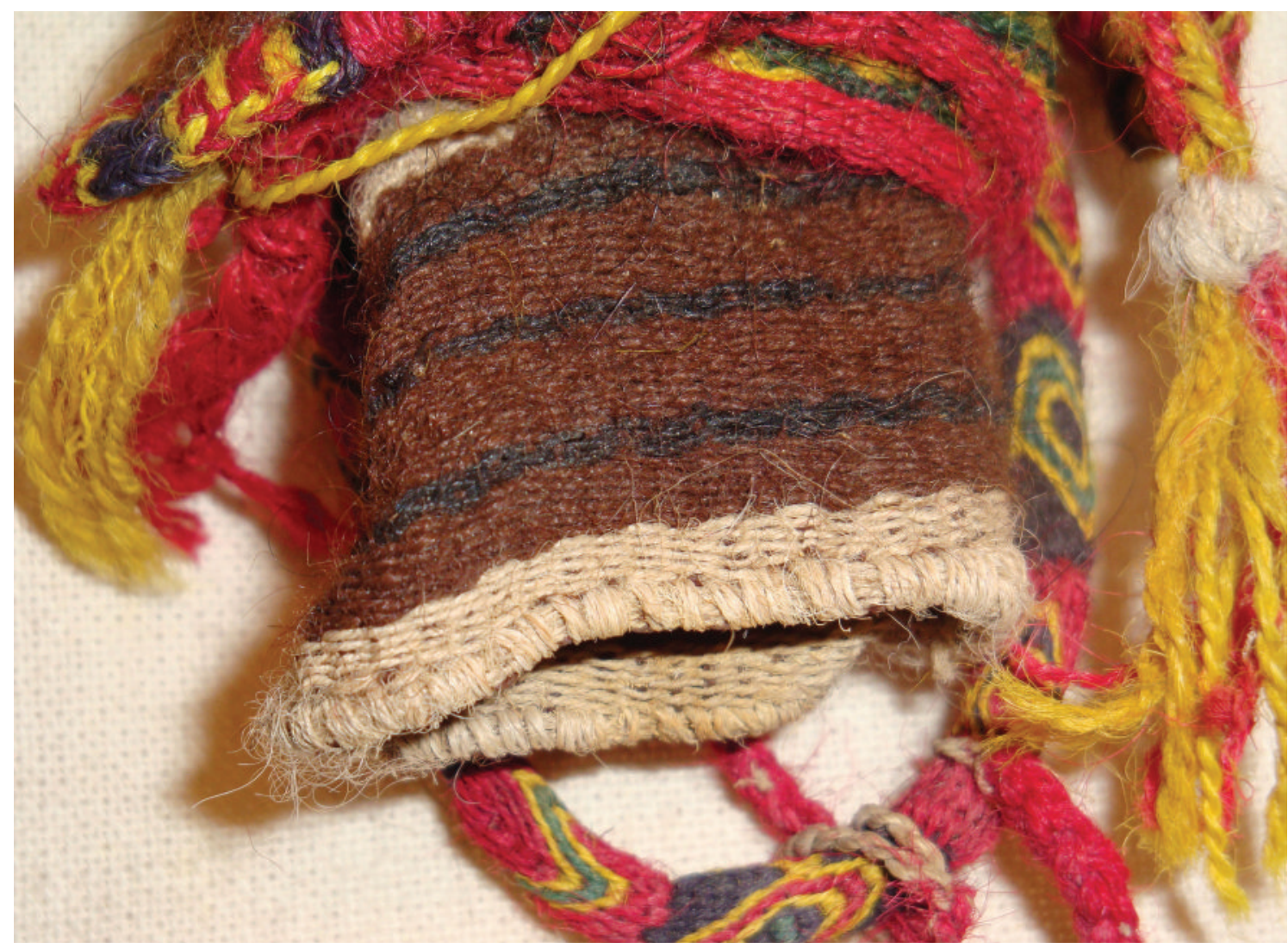

Figura 11. Listas oscuras sobre la banda café (LL-99-028). Figure 11. Dark stripes on the brown band (LL-99-028).

Otros trajes de estatuitas de capacocha, con diseño, que podrían considerarse muy semejantes entre sí, están presentes también en enterratorios bastante apartados. Algunas de sus coincidencias, casi exactas, han sido destacadas ya por Dranzart (1995). Al interior de este parecido se dan pequeñas diferencias: por ejemplo, el pallay de la vestimenta de la figurita desenterrada en Llullaillaco lleva un diseño que podemos interpretar como serpientes y es más ancho que su equivalente en el vestuario de la figurita desenterrada en Ambato (fig. 12). En otros casos, serpientes con cuerpos siempre quebrados, icónicamente perceptibles, se alternan con rectas más simples tan solamente en zigzag -acompañadas de ojos- en el vestuario de una misma estatuilla, sugiriendo una equivalencia de estos dos motivos: zigzag/serpientes.

Dranzart enfatiza igualmente las diferencias que son perceptibles entre diversos vestuarios en miniatura, provenientes de distintos enterratorios. Aquí nos estamos enfocando, preferentemente, en la repetición de un modelo de diseño sostenido a grandes distancias de espacios y tiempos. Pequeñas diferencias como, por ejemplo, lo que ocurre con la franja roja que encierra a los pallay: algunas veces cambia su tamaño, se ensancha o angosta; otras distinciones como esa podrían deberse al proceso de manufactura del tejedor o tejedora que interpreta un diseño dado, obligatorio, pero con algunas libertades que se le permiten. Sería difícil percibir un semantismo específico definido por estos pequeños detalles.

Se ha señalado que cada entidad sagrada -wak'aera imaginada vistiendo un traje parecido al del grupo étnico que la adoraba y recibiendo un culto específico, tal como lo recuerdan Bray et al. (2005: 84) cuando señalan que "Dado que todas las deidades debían recibir algún tipo de ofrenda, la cantidad y el valor del sacrificio a realizar variaba de acuerdo a las huacas".

Así, la semejanza del traje de figuritas entre diferentes enterratorios apartados plantea una duda: ¿es una misma deidad convocada a lo largo del Tawantisuyu, en las alturas de Llullaillaco, cerro Gallán, norte 


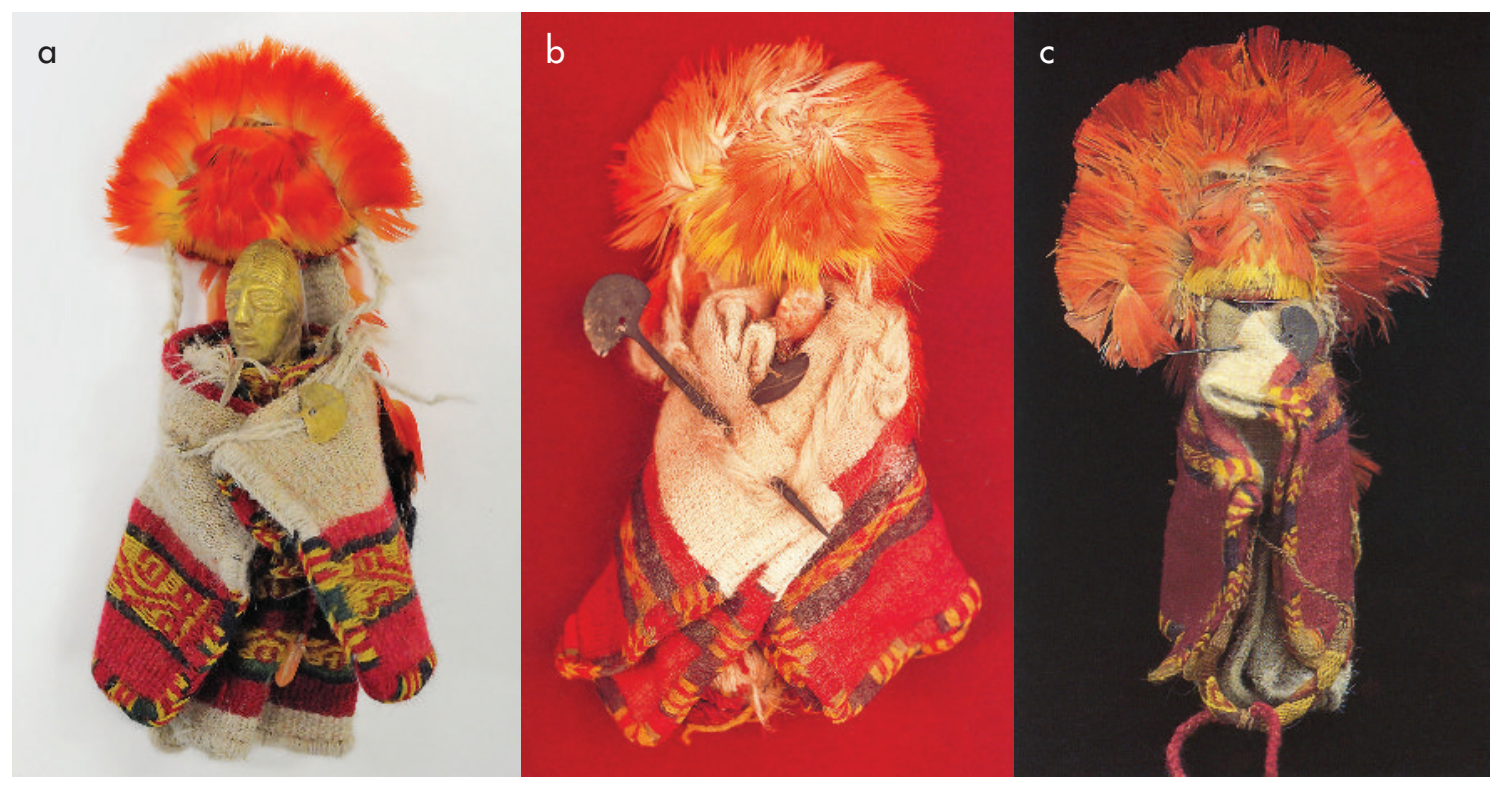

Figura 12. Vestuarios semejantes de pampas blancas y atuendos con plumas naranjas, en una estatuilla de oro, otra de Spondylus y una de plata: a) MAAM, Llullaillaco 99-054. En la lliklla las serpientes están claramente definidas; en el aqsu, en cambio, puede entreverse un zigzag continuo; b) figurita procedente de Ambato, Spondylus: vestuario que recuerda al anterior, pero ahora se ha tejido en la lliklla un zigzag continuo (Museo Universidad Católica Santa María, Arequipa); c) figurita de plata con ropajes semejantes (Tokyo National Museum): un mismo cromatismo en el vestuario, a pesar de las diferentes materias primas. Figure 12. Similar white pampas clothing and dress with orange feathers on a gold figurine, another of Spondylus, and a silver one a) MAAM, Llullaillaco 99-054. The lliklla has clearly delineated snakes on it, whereas the aqsu suggests a continuous zigzag; $\boldsymbol{b}$ ) figurine from Ambato, Spondylus: clothing reminiscent of the previous one, but with a continuous zigzag woven on the lliklla (Museo Universidad Católica Santa María, Arequipa); c) silver figurine with similar clothing (Tokyo National Museum): the same use of color on the clothing, despite the different raw materials.

argentino, Ambato, sur peruano, Las Tórtolas, límite entre Argentina y Chile, el Pili en Atacama, El Plomo en la cordillera central chilena, volcán Copiapó y en los demás santuarios de montañas?, ¿ o se trata de distintas deidades locales en esos cerros, unificadas al panteón inkaico por un mismo cuerpo y un mismo vestuario, a las que se les implora un mismo efecto ritual?

Estas prendas pueden haber sido tejidas según un modelo en cualquier lugar, no es eso lo que nos preocupa por el momento, sino el hecho de que han sido concebidas a través de un solo pensamiento intelectual y sensible. Un diseño invariable, a pesar de esas pequeñas diferencias en su ejecución. Una matriz que se extendió y conservó durante el Período Tardío del Tawantinsuyu. ¿A través de un trozo de tejido circulando, por generaciones, en manos de tejedoras o tejedores especializados?

\section{TERCERA INQUIETUD: LA NO IDENTIDAD DE ESTOS TRAJES CON LOS CONOCIDOS DE LAS COYAS}

En las numerosas representaciones de vestimentas de la nobleza inkaica, sea en los dibujos de Guamán Poma de Ayala o en las láminas que ilustran las dos crónicas de Martín de Murúa, ${ }^{19}$ no es posible observar personajes que, más allá del formato de las prendas, vistan trajes semejantes al de las pequeñas estatuitas, en colores y diseños. Naturalmente, se trata de dibujos o pinturas realizadas ya en la Colonia, en los que notamos algunas diferencias con las vestimentas en miniatura. Por ejemplo, la ausencia en estas últimas de la gran cantidad de tocapus ${ }^{20}$ que aparecen en los trajes ilustrados por los cronistas (fig. 13). ${ }^{21} \mathrm{Ni}$ en las dos ediciones de las crónicas de Murúa, ni en los dibujos de Guamán Poma, se observan diseños en trajes femeninos con serpientes en zigzag, aunque este ícono era más antiguo que el Estado Inka (detalle que ha sido señalado por Rowe 1995-1996). 


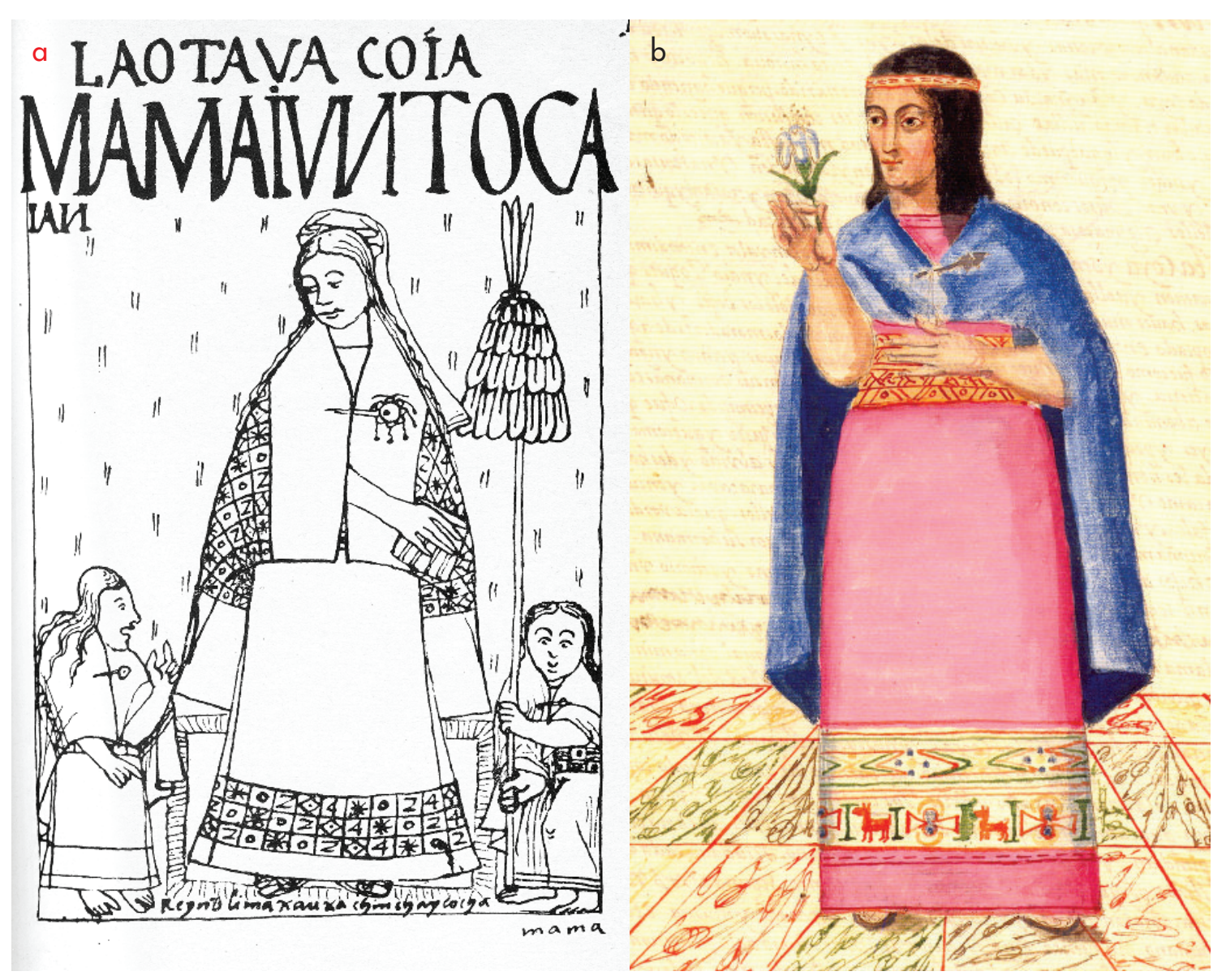

Figura 13: a) Mama Yunto Coya (Guamán Poma, f. 134); b) coya de Murúa (Manuscrito Getty, f. 23). Figure 13: a) Mama Yunto Coya (Guamán Poma, f. 134); b) Murúa’s Coya (Getty Manuscript, f. 23).

Tampoco encontramos en los trajes de las estatuillas de altura la gran variedad de tonos que iluminan los ejemplos de las coyas en Fray Martín de Murúa (en las dos versiones de su crónica), que están lejos de presentar esas estandarizaciones de las vestimentas de las estatuillas de altura. Podemos pensar que el cronista o quien fuera que los pintara, no se fijó bien en los colores dominantes en los trajes de su época, pero observó tantos detalles que asombran por su finura en sus ilustraciones (como los festones casi imperceptibles en los unkus masculinos), que es difícil pensar que no vio combinaciones cromáticas repetitivas como las que llevan las figuritas en las capacochas. Tal vez Murúa -o Guamán Poma, al que se le supone colaboración en estas representaciones- no reprodujo los tonos exactos, pero, al menos, su memoria debe haber registrado una profusión de colores (que posiblemente se continuaban en su variedad en el primer siglo de la Colonia) que no se corresponden con estos dos tipos tan normados.

Por lo general, el aqsu de las figuritas de enterratorios de cumbres coincide en diseño y en colores con la lliklla que lo acompaña, es decir, conforman un conjunto coherente, lo que no ocurre en las ilustraciones sobre trajes en la crónica de Murúa. En las figuritas femeninas, los aqsus con pampas blancas, con pampas oscuras o con pampas amarillas o verdes llevan su complemento en lliklla con pampa de estos mismos tonos, lo que hace a estas pequeñas vestimentas más intensamente significativas por su reiteración. Sin embargo, hay algunas excepciones: aqsu en tonos naturales, pero lliklla con pallay en colores (figurita del cerro El Plomo). La excepción más notable es la figurita 


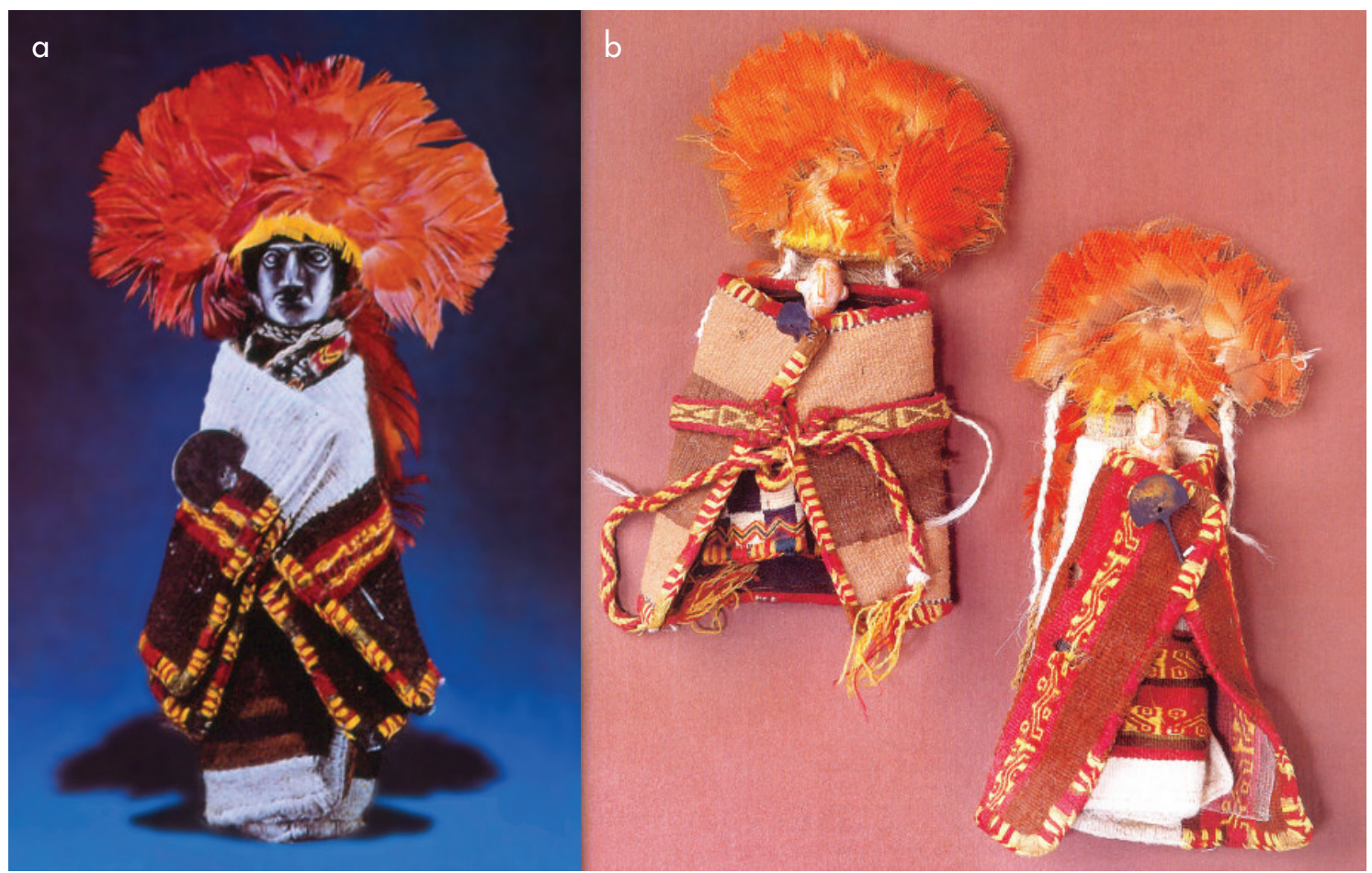

Figura 14: a) estatuilla femenina en cerro El Plomo: aqsu en tono natural. A pesar de que va casi tapado por la manta, se observa que su banda café lleva las listas negras citadas en los ejemplos de Lircay, Copiapó y Llullaillaco. La lliklla lleva, en cambio, tonos teñidos y dibujos. (Fotografía: gentileza Museo Nacional de Historia Natural); b) otra figurita atípica: cuerpo masculino (izq.) -se entrevé el unku en damero-, pero atuendo cefálico y chumpi femenino (MNAAH en De Rojas 2008: 79). Figure 14: a) female figurine in Cerro El Plomo: aqsu in natural color. Although it is almost completely covered by the blanket, it can be observed that its brown band has the black stripes mentioned in the Lircay, Copiapó, and Llullaillaco examples. On the other hand, the lliklla has dyed colors and drawings (Photograph: courtesy of Museo Nacional de Historia Natural); b) another atypical figurine: male body (left) - a glimpse of the unku can be seen on a checkered pattern-, but with a cephalic garment and in female chumpi (MNAAH in De Rojas 2008: 79).

masculina vestida con un unku (camisa del hombre) adecuado a su sexo, en este caso en damero, llevando, sin embargo, otras prendas exclusivamente femeninas como el atuendo de plumas cefálico y un chumpi (fig. 14). ¿Descuido de quien la vistió en ese entonces?, ¿ prisa por entregar la figurita ante la inminente partida de la caravana que la llevaría a su destino? o ¿estatuilla vestida muy posteriormente a su encuentro, por personas que desconocían el uso de estas vestimentas? Se trata de casos particulares.

\section{ÚLTIMA INQUIETUD: LA NO SEMEJANZA DEL AQSU O DE LA LLIKLLA DE LAS ESTATUITAS CON LAS PRENDAS USADAS POR LAS MUCHACHAS O NIÑAS SACRIFICADAS, A LAS QUE ACOMPAÑAN EN LOS ENTERRATORIOS DE ALTURA}

Ninguno de los cuerpos femeninos sacrificados lleva un aqsu igual al que visten sus diminutas compañeras. Aunque más adelante mencionaremos algunos aqsus de formato mayor, con el mismo diseño, encontrados junto a los cuerpos de muchachas enterradas, no hay evidencia de que los llevaran puestos cogidos con dos tupus a sus hombros, es decir, que las prendas vistieran a los cuerpos de las muchachas en su vida o en su muerte. Al menos para Llullaillaco, Ceruti señala que la diferen- 

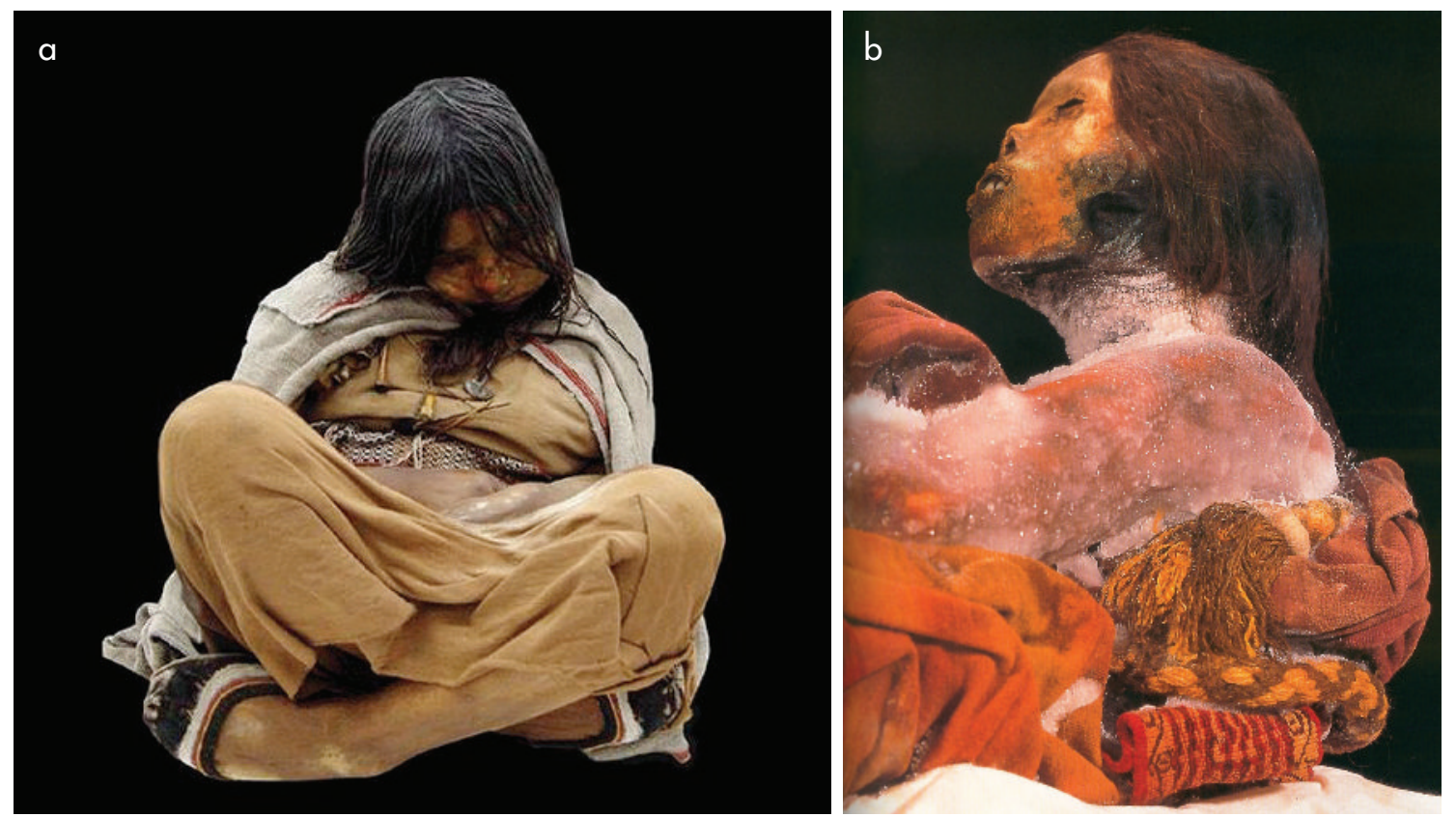

Figura 15: a) "Doncella" de Llullaillaco (MAAм). Su vestido es perfectamente visible, sin dibujos ni tonos teñidos y sin bandas; b) "Juanita" (Museo de Santuarios de Altura del Sur Andino, Ambato, Arequipa). ${ }^{23} \mathrm{Su}$ aqsu tampoco se corresponde con los de las miniaturas: café, sin diseños, aunque con bandas de colores vivos (Conklin 1996: 105). Son cuerpos con una extraordinaria momificación natural. Figure 15: a) Llullaillaco "Maiden" (MAAM). Her dress is perfectly visible, with neither drawings nor dyed colors and without bands; $\boldsymbol{b}$ ) "Juanita" (Museo de Santuarios de Altura del Sur Andino, Ambato, Arequipa). Her aqsu does not correspond to that of the figurines either: brown, without patterns, but with bright colors bands (Conklin 1996: 105). These corpses feature an extraordinary level of natural mummification.

cia empleada para la deformación craneana de los tres infantes indicaría su distinta procedencia étnica. ${ }^{22}$ Para el niño encontrado en el cerro El Plomo se ha podido identificar un vestuario no cusqueño, proveniente más bien de grupos aymaras del Collao (Horta 2018: 377), lo que reafirma la no semejanza entre vestimentas de las momias - procedentes de distintas regiones de los Andes- $y$ las de las figuritas depositadas por los cusqueños.

Pensamos que, en el caso de las pequeñas estatuas de capacocha, se trata de vestimentas rituales para una ceremonia específica-sacrificios humanos de infantes, es decir, enfrentamiento con la muerte, en sitios elevados o sus equivalentes-, no repetidas en la vida diaria de la alta nobleza de mujeres inka. Esta impresión da, también, la presencia de los impresionantes tocados de plumas; algo que aparentemente no era habitual en los atuendos femeninos normales de esa época. Con ocasión de ceremonias importantes se usaban vestimentas excepcionales, según relatan algunos cronistas, bajo el principio de que cada situación precisa un traje propio. No obstante, ninguno coincide con el vestuario de las figuritas de altura. No solo cada ritual estaba definido por un ropaje, sino que, según relata Molina, en cada fase de él las prendas cambiaban, lo que hace pensar en la gran cantidad de tejidos que eran elaborados para cada persona. Para las mujeres, el cronista describe solamente un vestuario en las ceremonias en que los adolescentes se armaban caballeros: "[A las doncellas] les hacía dar a cada una d'ellas un vestido que era el axsu colorado y blanco llamado angallo y la lliclla de lo mismo" (Molina 2010 [1575]: 73).

Cada ritual con su traje específico. Rojo y blanco eran al parecer los colores apropiados para el cambio de edad, ya que las niñas usaban también angallo en sus ritos de pubertad (Molina 2010 [1575]: 88.) Esta combinación no la encontramos en los pequeños trajes femeninos. Recordemos que el rojo forma parte de las franjas con dibujos, comunes a todos los trajes con pallay. ¿A quién pertenecieron estos trajes de las miniaturas femeninas, si es que pertenecieron a alguien?

Dranzart (1995: 16) sugiere posibles propietarias de estos diferentes tipos de vestuarios femeninos en 
miniatura, una propuesta que ha sido seguida luego por otros estudiosos de este tema (Martínez 2007, Hoces \& Rojas 2016). Los trajes de las figuritas se corresponderían con los atuendos de las aqllas, las mujeres escogidas, de gran belleza, que vivían y trabajaban en las aqlla wasi. ${ }^{24}$ Habrían sido utilizados ya por esas mujeres escogidas y no solamente tejidos por ellas. ¿Pudo ser así?

Recordemos que tanto Bertonio como Ramos Gavilán nos hablan de tres niveles de jerarquía en estas mujeres tan hermosas como perfectas, jerarquías en las cuales se las identifica por colores: paqo, de color alazán encendido usado para mujeres consideradas no suficientemente bellas; janq'o, blanco, para mujeres muy bellas; y wayruru, correspondiendo a la combinación rojo/negro de una pequeña semilla, para mujeres de suprema belleza (Cereceda 2017 [1987]). Ramos Gavilán repite este orden, pero transforma la voz aymara janq'o, por yuraq, en quechua; sin embargo, se trata de la misma organización de belleza y color (Ramos Gavilán 1976 [1621]: 62). Para Santa Cruz Pachacuti (1993 [1613]: 290) los tipos de aqlla son cuatro: agrega las aqllas negras, yana. Es difícil, sin embargo, hacer corresponder esos tres o cuatro nombres de colores dados a las aqllas, los más frecuentemente nominados por los cronistas, con las tonalidades en los trajes de las estatuitas.

Paqo, las mujeres no suficientemente bellas, podrían identificarse con figuritas femeninas vestidas en tonos naturales de alpaca o vicuña, ya que el término corresponde a un “alazán", café encendido, no teñido (Bertonio 1984 [1612]: 242, tomo II); para janq'o (blanco) no hay problema, serían las vestimentas ya con dibujos, pero con pampas blancas. Pero ¿yana y wayruru? Tenemos aqsu y lliklla en miniaturas con pampas negras -yanaque podrían corresponder a este primer tipo de aqlla, siguiendo la secuencia de los tonos de las pampas. Pero, entonces, ¿cuáles serían las wayrurus -rojo y negrolas aqllas más destacadas y en cuyo nombre todos los cronistas coinciden?

Las pampas oscuras no pueden adjudicarse simultáneamente a dos tipos de aqlla, para que correspondan a la vez a las yana como a las wayrurus (en este último caso se juntaría el negro con el color rojo de las franjas donde van los motivos del pallay, rojo que corresponde a todos los tipos que llevan estos dibujos, lo que eliminaría la lógica de la secuencia). Incluso, tanto en Llullaillaco como en Túcume, hay figuritas cuyos trajes llevan pampas en un amarillo encendido -qellu- que los cronistas no citan y que no era, al parecer, un color frecuente para definir a las mujeres escogidas, tampoco el verde de algunas bandas se correspondería con vestimentas de aqllas.

Más recientemente, Barraza relaciona las figuras femeninas en pinturas de la cerámica llamada Cusco Polícromo Figurado (subestilo de Ink a Imperial según Barraza 2012) con personajes que representarían aqllas. Si así fuese, tendríamos una imagen visual concreta de ellas para reconocer sus vestuarios y compararlos con los de las figuritas de altura. Él distingue tres tipos de aqsu en estas representaciones de mujeres: túnicas cafés (posiblemente paqo), túnicas rojas y negras (wayruru) y túnicas enteramente oscuras. Según este investigador, serían las yana aqlla, lo que es muy convincente. ${ }^{25}$ Pero ninguna de las túnicas pintadas en la cerámica polícroma cusqueña, a pesar del enorme interés que nos causa verlas, se correspondería con el vestuario de las figuritas: es interesante ver que el rojo de los aqsus que serían las wayrurus va cercano al cuello y hombros de la portadora y no en bandas, que es la característica de las prendas en miniatura de los santuarios de altura. Y, como señalamos, el rojo en las pequeñas vestimentas corresponde a las franjas con pallay, común a todos los colores de pampas; $y$, naturalmente, no hay ninguna serpiente (Barraza 2012). La propuesta de identidad entre la apariencia de las mujeres escogidas y la de las figuritas de altura, que han sugerido varias investigadoras, no es fácil de sostener. ${ }^{26}$

Si no representan a la nobleza femenina inka y es difícil hacerlas coincidir con el traje de las mujeres escogidas citadas por los cronistas, ¿qué evocan estos trajes?

Martínez (2007: 29) sostiene otra posible procedencia para estas diferencias cromáticas, señalando que corresponderían a las distintas panacas, supuestos grupos de filiación descendientes de un Inka difunto. Sin embargo, el número de estas estructuras familiares excede en mucho el número de tipos de colores que organizan los vestuarios de figuritas de altura, esas serían diez o doce panacas, y no hay datos que muestren que estos distintos grupos de descendencia inkaica llevasen vestuarios que los definieran. Más aún, en los trajes de estatuillas de personajes masculinos, en los mismos enterratorios de cumbres -no abordados aquí-, solo son visibles unos pocos tipos de unkus (camisa del hombre): sería imposible hacerlos corresponder con el mucho mayor grupo de panacas. ${ }^{27}$

Artzi, por su parte, sugiere una nueva relación para estos trajes en miniatura de diferente colorido. 
Responderían a las "alegorías" -que ella, en principio, desprende de los dibujos de Guamán Poma- de las cuatro "señoras" que encarnarían simbólicamente los cuatro suyus del Inkario (Artzi 2016: 323-330).

Una propuesta innovadora y tentadora -cuatro tipos de vestimentas con diferentes colores de pampa: cuatro suyus- sugiere que la correspondencia entre cada tipo de vestuario de estatuillas de santuarios de altura en colores vivos y distinguidos por sus pampas blancas, negras, amarillas o verdes, y cada una de las partes en que se dividía el Inkario. Si fuese así, ¿cómo clasificar, también, a aquellas sin dibujos ni tonos teñidos? No hay un quinto suyu y quedarían fuera en la representación del Estado Inka. Es interesante la interpretación alegórica que hace Artzi de estas mujeres dibujadas por el cronista. No obstante, la posible representación de los suyus, no coincide necesariamente con los atuendos de las figuritas. Y ¿cómo podríamos explicar, en alegorías, la presencia de rasgos tan delicados y casi imperceptibles como, por ejemplo, listas negras en las bandas cafés de las figuras $10 \mathrm{~b}$ y 11 ? Tendrían que ser mucho más simples y generales.

Los vestuarios que no llevan diseños ni tonos teñidos (salvo, a veces, colores vivos en sus angostos festones), plantean problemas en cuanto a su participación en categorías del Tawantinsuyu o su posible representación de su uso en otros contextos. Es interesante notar que algunos de los aqsus en tonos naturales llevan una estructura especial: las bandas de arriba y de abajo de estas prendas coinciden en ser de diferente color, una más clara, la otra más oscura, como se pudo observar en las figuras 9 y 10.

Curiosamente, como ya notamos, se trata de una organización cromática asimétrica -no presente, por lo general en manufacturas inkaicas- que no se repite en los aqsus con dibujos y tonos obtenidos por tintorería. Hay figuritas femeninas que visten estos atuendos y pueden ser de plata o de Spondylus. ¿A qué corresponden?

Quisiéramos recordar la clasificación de los colores de hilos para tejer, en el ayllu aymara de Isluga, altiplano hoy chileno: se categorizan en dos tipos determinantes que, incluso, llevan nombres propios: k'ura, para los tonos naturales del vellón de camélidos cuando no han pasado por un proceso de tintorería, y, en cambio, pana para los tonos obtenidos por tintes, que se aplican más usualmente al vellón de ovejas (Cereceda 2017: 11-42, 111-185). Lo interesante es que esta clasificación define el uso diferenciado de estos hilos k'ura o pana, no sola- mente para distintas prendas sino, incluso, para partes específicas al interior de un textil. ¿No estaríamos también frente a una etnocategorización inkaica que oponía las prendas con colores de hilos teñidos y no teñidos?

Es necesario mencionar la existencia de dos diferencias más entre las llikllas tejidas con bandas de tonos naturales: ${ }^{28}$ las que tienen festones en los mismos colores que las bandas y las que tienen festones de tonos teñidos, conservando las bandas sin tintorería (fig. 16).

Fue posible observar el primer tipo en las figuras 9 y 10. Las dos maneras diferentes de contornos, se distinguen no solamente en los colores de los bordes, sino en que unas llikllas son asimétricas y las otras, con festones vivos, perfectamente simétricas. Un rasgo que es importante notar.

Estos ropajes en miniatura, además de otros semantismos cuya lectura intentaremos más adelante, deben expresar un contenido de identidad de las figuritas que los usan. Aquellos con diversos colores y la técnica del pallay logrando dibujos bien definidos a pesar del tamaño del diseño -que han sido calificados incluso como cumbi por algunos arqueólogos ${ }^{29}$ constituyen la gran mayoría y no presentan problemas en su categorización: corresponden a las excelentes calidades de los textiles de la clase alta cusqueña. Sin embargo, en los enterratorios hay también pequeñas llikllas sin dibujos, pero con festones en colores vivos. ¿Un estilo intermedio, diríamos, entre las extremas sofisticaciones técnicas y otras más sencillas sin tintorería? Hacen pensar en la presencia de personaje votivos, en estas grandes ceremonias, ya no de la nobleza, sino, posiblemente, de las otras clases sociales en la ciudad o, tal vez, de grupos de la periferia del Cusco. Festones en tonos naturales (figs. 9 y 10) o bordados en colores vivos (fig. 16), en la condensación simbólica que llevan los diminutos ropajes, deben enviar, necesariamente, a diferentes identidades.

¿Y las llikllas sin un solo color vivo y en disposición asimétrica? No pueden dejar de recordarnos el extendido relato mítico, vigente hasta nuestros días, de seres de otra humanidad que existió cuando aún no había surgido el sol, teniendo una visión estetoscópica de la realidad, bajo la luz de la luna. Es decir, sin una visión de un mundo en colores. Y sin organizaciones sociales duales, opuestas simétricamente. ¿Esas prendas envían a la presencia viva aún de una larga memoria de gente de épocas oscuras, que no dominaban técnicas sofisticadas en el arte de tejer?, ¿o a grupos contemporáneos de los inkas, pero considerados como los restos o descendientes de esa 


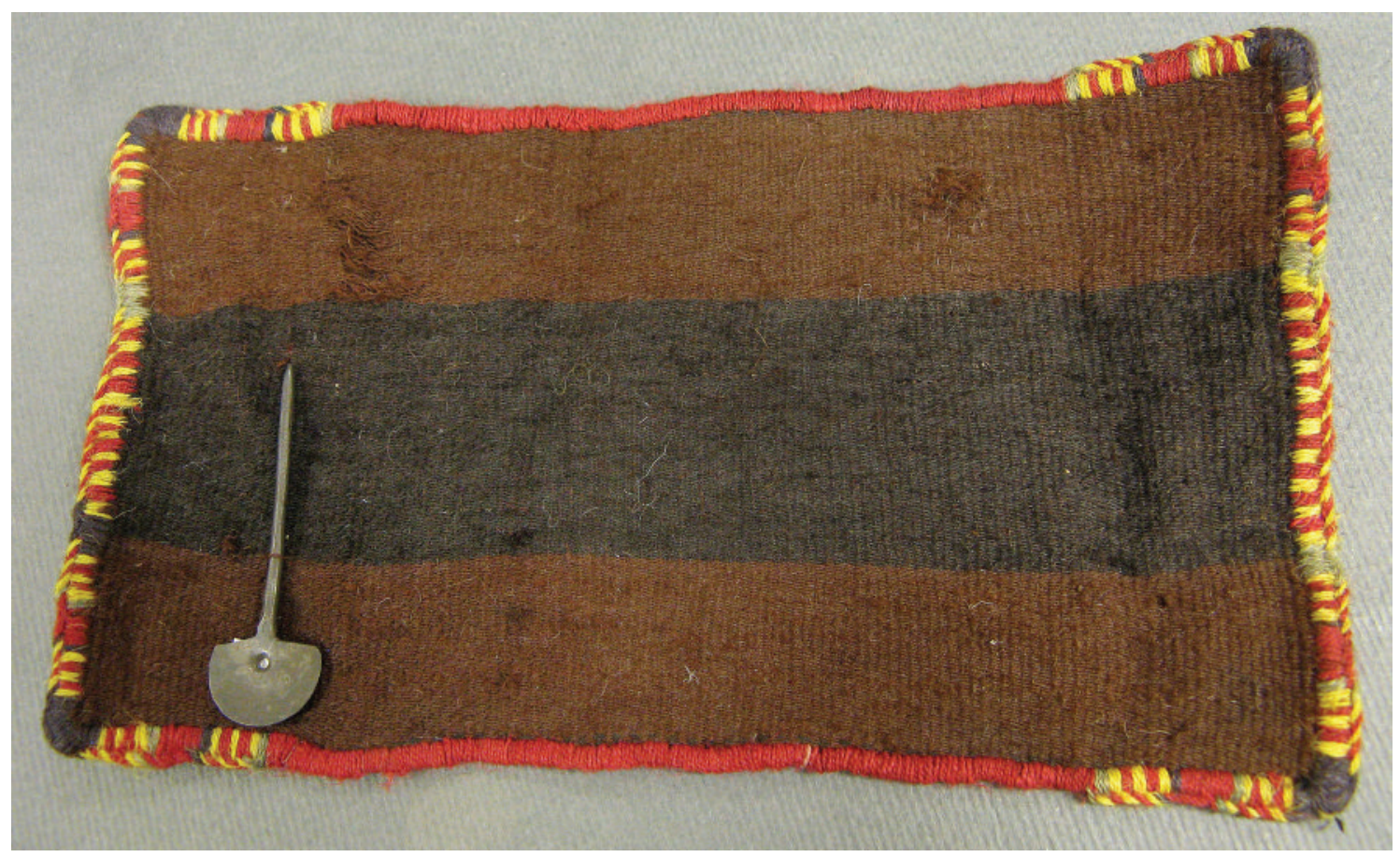

Figura 16. Lliklla de bandas en tonos naturales de vellón de camélidos y festones en colores vivos obtenidos por tintorería. Figure 16. Lliklla with natural color stripes made of camelid fleece and festoons in bright colors obtained by dyeing.

otra humanidad, conocidos como chulpa puchu, purun runa, $\mathrm{u}$ otros nombres? Gary Urton nos da un amplio panorama de la heterogénea población que habitaba tanto el Cusco como su periferia (Urton 2004). Pero ¿por qué su recuerdo o presencia viva estaría evocada en las capacochas? Regresaremos, más adelante, a este problema.

Cabe preguntarse también si, entre las deidades convocadas en las altas cumbres, algunas tendrían este estatus de más primitivas, consideradas como perteneciendo a los pueblos que existieron en tiempos oscuros, y sus vestimentas fueron reproducidas en épocas del Tawantinsuyu, para evocarlas en conjunto con el panteón inkaico. Tal vez, el Estado Inka, con su pasado y su presente, con su centro y periferia, representado en las figuritas, precisara actuar como un todo al comunicarse con las fuerzas sobrenaturales, para solicitar lo que, vehementemente, se esperaba de estos rituales.

Nos hemos detenido en las posibles pertenencias de estos trajes para sugerir que no fueron utilizados por otras mujeres en sus vidas tal como se encuentran vistiendo a las figuritas; serían, más bien, organizaciones simbólicas de identidades trascedentes, diseñadas para las necesidades de las capacochas. Las agencias ceremo- niales de estas imágenes tejidas, de sus texturas, estarían vinculadas muy estrechamente a estos enterratorios y deberíamos considerarlas en esta dimensión.

\section{Entrando en los diseños de los pequeños aqsu y lliklla}

En las figuras anteriores hemos observado los pallay, tema de este trabajo. A pesar de sus tamaños, no caracterizan solamente a sus portadoras, sino que, dada sus insistencias -son los únicos posibles en aqsu y lliklla en las figuritas- deben haber cumplido un rol propio e importante en medio de las ofrendas enterradas junto a los cuerpos de niños, niñas o jóvenes sacrificados. Uno de sus rasgos principales es el hecho de que sus elementos componentes no están dispuestos de manera dispersa sobre un fondo abierto, sino como dibujos comprimidos en espacios alargados y estrechos. Los espacios van cercados por listas negras, arriba y abajo, o en uno de sus dos lados. Estas listas no solamente los destacan, sino que los identifican como unidades semánticas, en sí mismas, al interior de la franja roja en la que siempre van insertos. 
Sus rasgos distintivos son:

1) Un zigzag continuo al que acompañan círculos que recuerdan “ojos”, situados en los triángulos que dejan las rectas quebradas. Este diseño más simple, lleva solo un círculo en sus ángulos. Sin embargo, el zigzag termina siempre en lo que parece ser una pequeña cabeza de ofidio, como puede observarse insinuada en esta lliklla de la figura 17.

2) Rectángulos que alternan su cromatismo segmentando el espacio continuo del zigzag. Unos rectángulos van en fondo amarillo con las figuras en rojo, los otros en fondo rojo con las figuras en amarillo.

3) Si hay rectángulos, en cada uno se ubica el ícono reiterativo de una serpiente, con su cuerpo zigzagueante, bicéfala, una cabeza en su inicio y otra en su cola. ${ }^{30}$

4) Hay dos variantes posibles de la presentación de las serpientes: el cuerpo de los ofidios va determinado solo por dos rectas que, por ocupar menos espacio, permiten la inserción de una mayor cantidad de círculos o formas casi circulares en los espacios vacíos que dejan los cuerpos con sus formas en zigzag; o va dibujado con tres rectas paralelas, una en su interior, con un cuerpo más ancho y solamente con un círculo o su equivalente, en los ángulos. ${ }^{31}$

5) Entre estos espacios generalmente con dos diseños, se integra, a veces, un tercer pallay, siempre más oscurecido. En él, los rectángulos se alternan entre un fondo negro con serpientes en rojo, o un fondo rojo con serpientes en negro. Este tercer pallay queda al interior, rodeado o encerrado por los pallay más vivos y brillantes. Curiosamente, en estudios anteriores, no ha sido destacada su presencia ni su posible semantismo.

Los diseños llevan otro rasgo importante que, igualmente, no ha sido considerado hasta ahora: cortos trazos rectos unen los cuerpos de las serpientes sea entre sí, sea adhiriéndolos al borde exterior de las franjas, o las serpientes comienzan directamente de esos bordes.

El efecto óptico es que todas esas rectas más los círculos conforman un espacio compacto, una única unidad significativa, un todo, donde cada elemento debería ser leído con relación a los otros. Las rectas que enlazan a las serpientes deben afectar necesariamente el contenido de estas imágenes: los amarus parecen estar amarrados o sujetos.

Se diseñan, también, formas gráficas repetitivas -triángulos, rombos y a veces, hasta hexágonos- y las

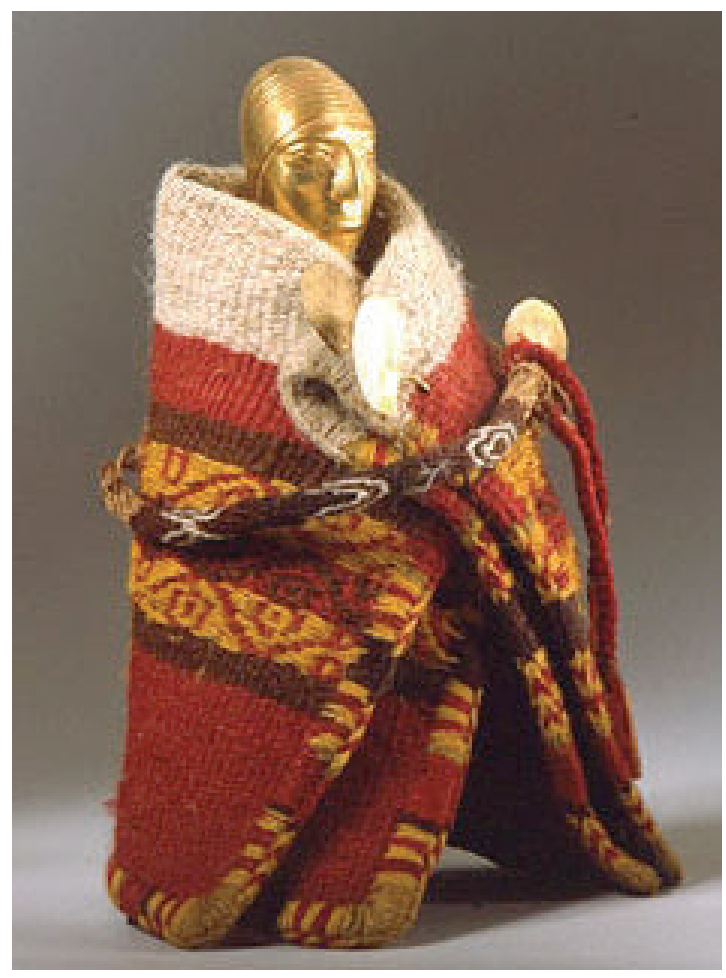

Figura 17. Zigzag continuo con un solo ojo. Figure 17. Continuous zigzag with only one eye.

cabezas de los ofidios que se encuentran entre ellas, sea arriba o abajo, producen el efecto de una continuidad. Estas dos sensaciones: "un todo único, compacto" y "continuo" en los rectángulos, nos obligan a leer los distintos motivos en conjunto, una interrelación que debe ir perfilando el tema y su acción ritual, más allá del contenido que puede articular la serpiente a solas.

Aislando rasgos en este universo visual y sensual, tenemos algunas invariantes.

\section{EL CROMATISMO}

Los colores de las vestimentas de las figuritas femeninas en enterratorios de altura, salvo en pequeños detalles, son muy bien definidos. ${ }^{32} \mathrm{El}$ diseño de las serpientes en zigzag va en solo tres colores: amarillo y rojo, en los rectángulos, y, en menos proporción, rojo y negro, cuando estos rectángulos se ubican en una franja interior (figs. 18 y 19).

En esta propuesta óptica estamos considerando al amarillo y al rojo no como valores independientes uno 


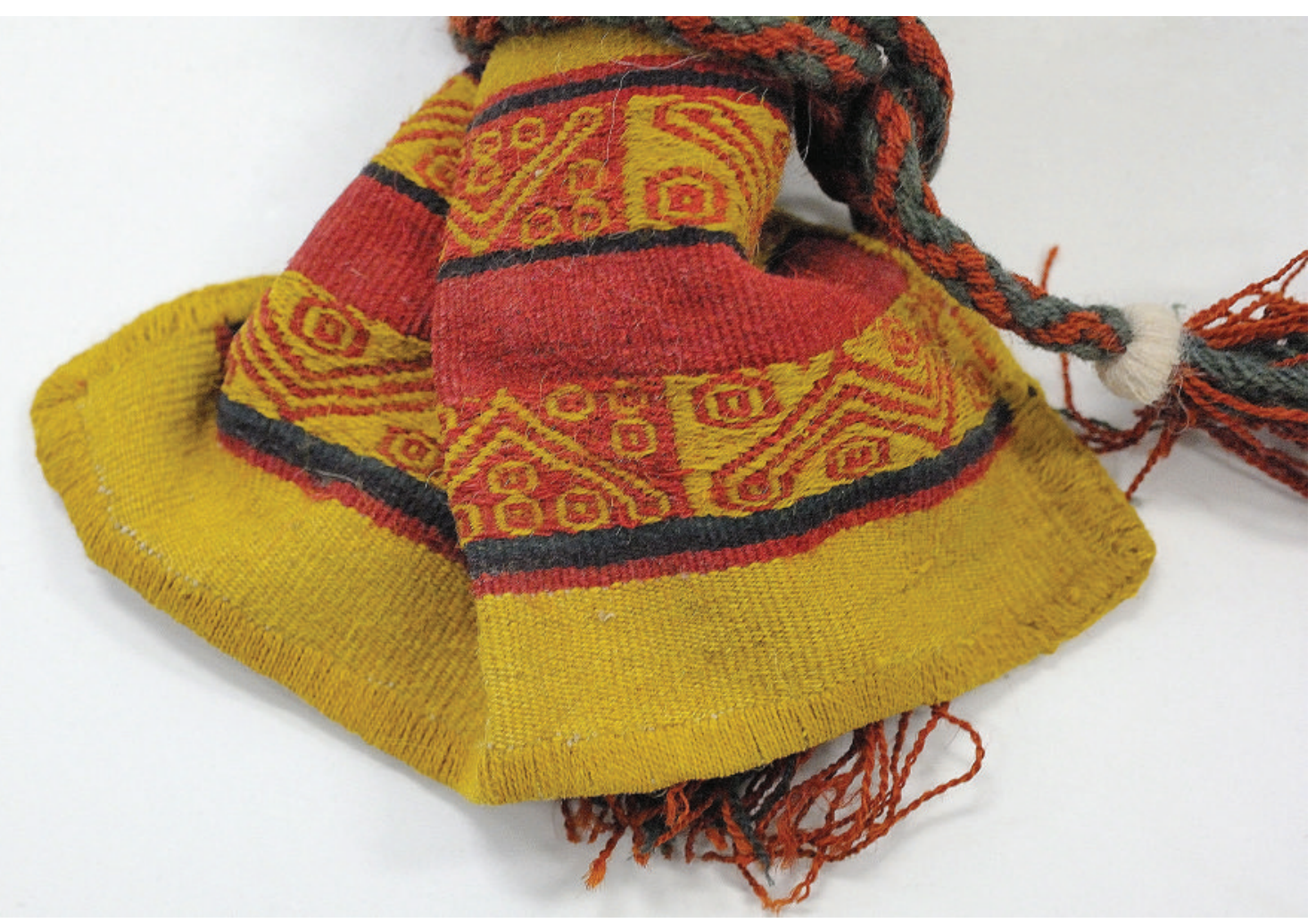

Figura 18. Serpientes bicéfalas con dos tipos de cuerpos. En rojo, dos rectas, en amarillo, tres. Figure 18. Double-headed snakes with two types of bodies. Two straight snakes in red, three in yellow.

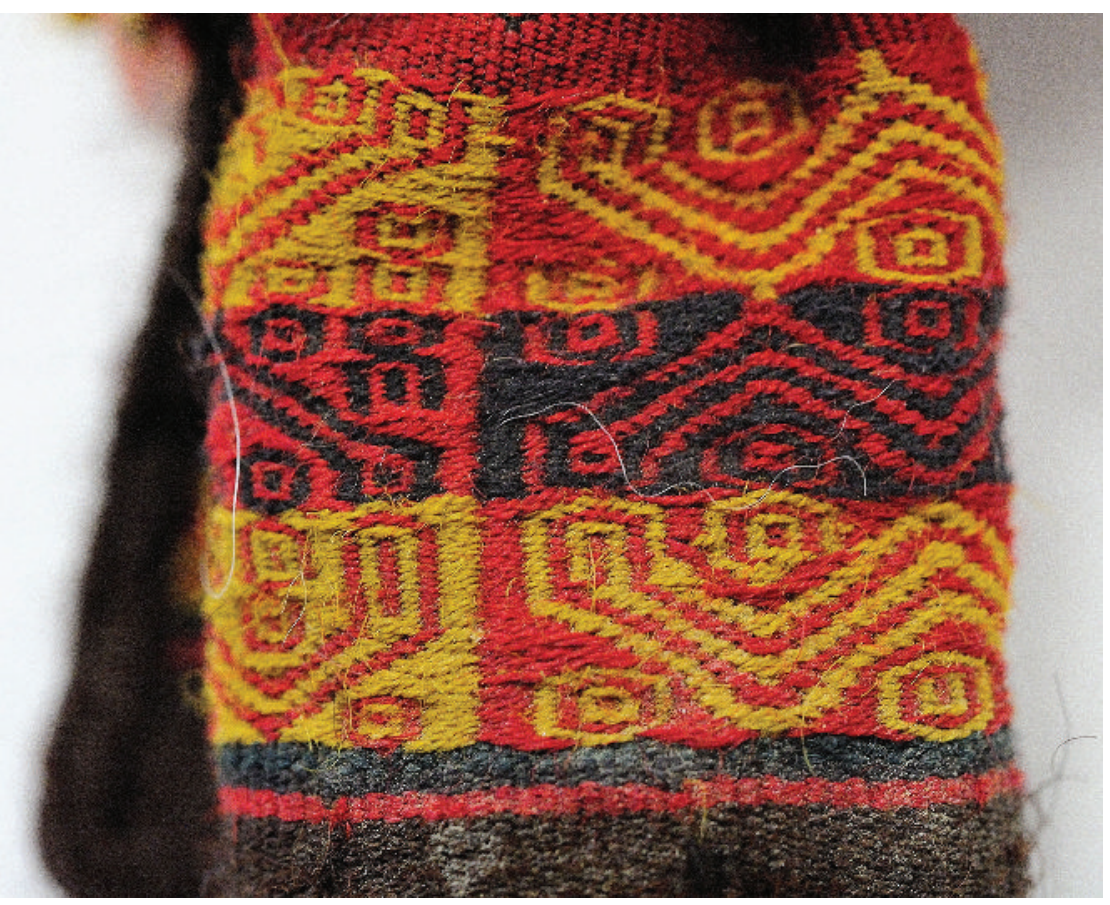

Figura 19. A veces un tercer pallay oscurecido aparece entre dos otros pallay más luminosos (LL-99-022). Figure 19. Sometimes, a third darkened pallay appears between two others brighter pallay (LL-99-022). 


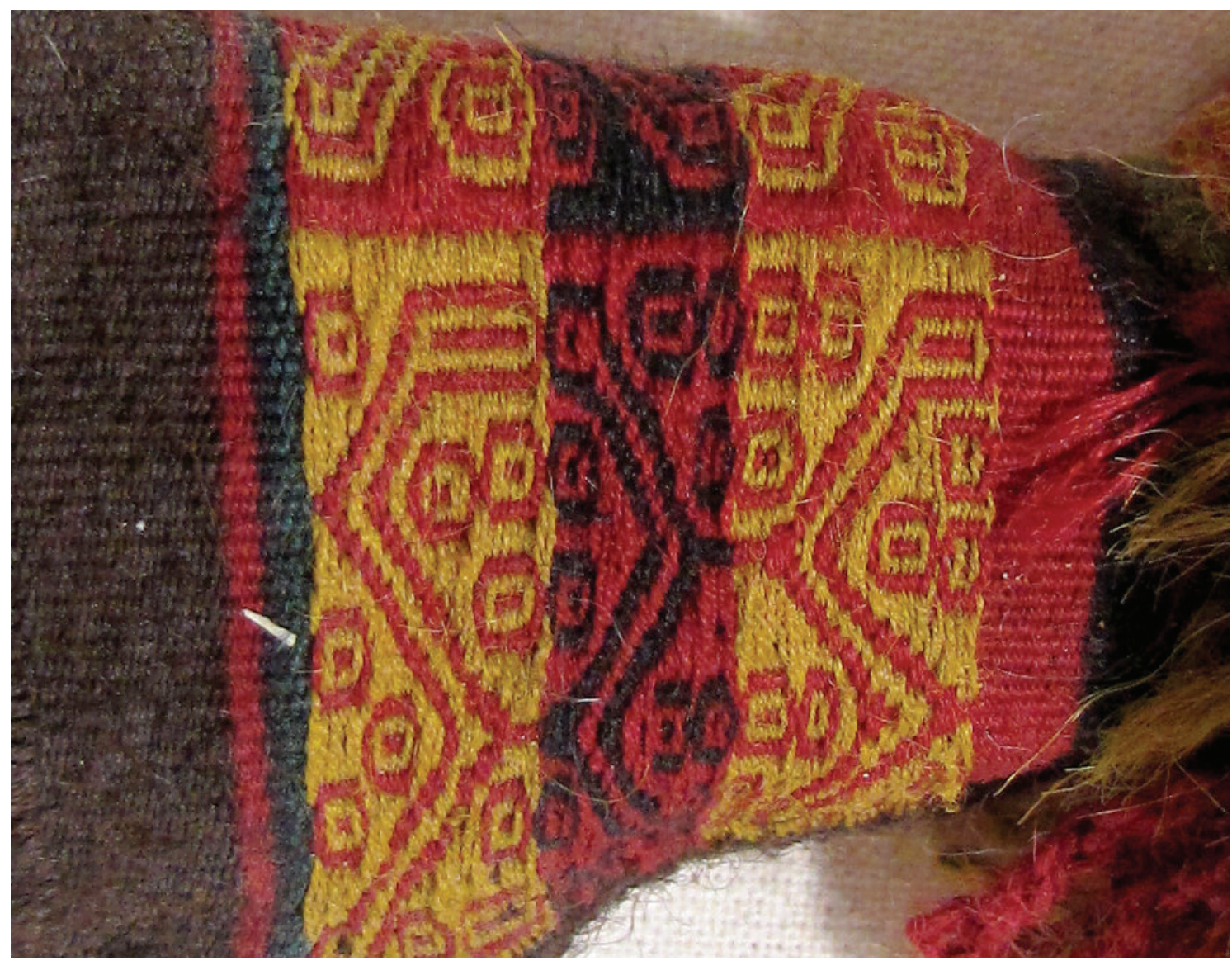

Figura 20. Los distintos elementos se unen entre sí formando diferentes dibujos y nuevas organizaciones de ojos (Llullaillaco 99-066). Figure 20. The different elements join together to form different drawings and new eye arrangements (Llullaillaco 99-066).

del otro, sino conformando una sola unidad, bicolor. Se trata de una estructura cromática invariable. ¿Qué está expresando?

En un intento de comprensión de este diseño sería imposible dejar de lado esta organización repetitiva de colores. ¿De qué está hablando?, ¿qué papel ritual está jugando? Se nos vienen a la mente las luces amarillas y rojas que acompañan el surgimiento de nuevas deidades en el conocido manuscrito de los ritos y tradiciones de Huarochirí. Pariacaca, el principal dios naciente, convertido en cinco hombres, cae sobre sus enemigos como una lluvia, y "esta lluvia era amarilla y roja". ¿ Por qué de estos colores? ¿Por qué esta dualidad cromática? También, "bajo la forma de granizo amarillo y rojo, arrasó a toda aquella gente empujándola hasta el mar...” (¿Tomás? 2008: 43 y 51). Un Pachacuti, una nueva era está definida por el surgir de esas luces. Y el relato evoca, también junto a esta organización cromática, amarillo y rojo, que la acompaña, los tiempos anteriores más oscuros. Entre algunas de las deidades que preceden a Pariacaca, el primer lugar lo ocupan Yanayamca y Tutañamca, es decir por los calificativos de yana y tuta, dioses de lo oscuro (yana, negro) y de la noche (tuta, noche). Y uno de los hijos de Pariacaca lleva, justamente, el nombre de Tutaykiri, es decir, "el que rompe la oscuridad".

Este cambio ocurrido en la iluminación del mundo en un pasado remoto, de las tinieblas o penumbra a la plena luz, se narra en innumerables relatos andinos hasta nuestros días, y en muchos, esta transformación cósmica va relacionada directamente con la aparición de una nueva humanidad, una humanidad en un ambiente ya solar, en la cual se incluyen los inkas (Cereceda 2017).

Amarillo y rojo parecen haber sido una de las combinaciones cromáticas emblemáticas del Tawantinsuyu. 


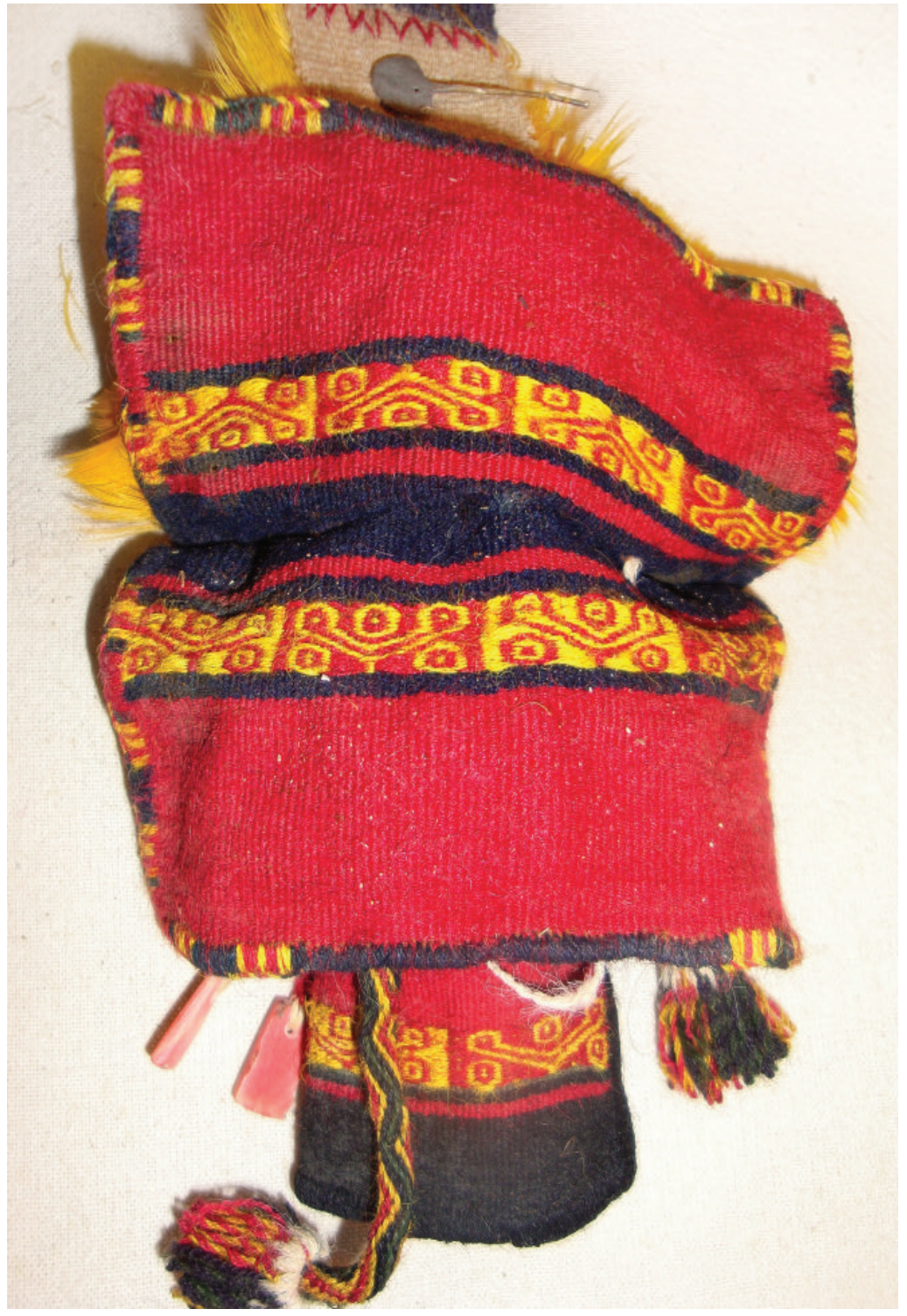

Figura 21. Circundan el pallay listas negras o, a veces, de otros colores, dándole un especial realce o señalando el paso entre espacio llano y espacio con relieve (urdimbres complementarias), que es un paso también semántico (LL-99-013). Figure 21. Black stripes, and sometimes of other colors, surround the pallay, enhancing it or indicating the passage between flat space and relief space (complementary warps), which is also a semantic movement (LL-99-013).
Según Garcilaso, las mujeres del sol "hacían unas borlas pequeñas de dos colores, amarillo y colorado [paicha] las cuales no eran para el Inka sino para los de su sangre real. Traíanlas sobre su cabeza. Caían las borlas sobre la sien derecha" (Garcilaso 1991 [1590]: 208).

De las insignias que el Inka Manco Cápac traía en la cabeza reservó una sola para sí y para los reyes sus descendientes, la cual era una borla colorada a manera de rapacejo que se tendía por la frente de una sien a otra. El príncipe heredero la traía amarilla y menor que la del padre (Garcilaso 1991 [1590]: 28).
Para Gentile (1999: 90) esta conjunción de colores estaría relacionada con el culto al sol que definía la identidad religiosa Inca, después del gobierno del Inka Pachakuti: "El sol aparece en las mañanas como amarillo, pero cuando se pone, como rojo [...] Estos tonos fueron los empleados para expresar la síntesis de su presencia".

Y para confirmar la relación de esta organización cromática con la invocación o alusión al sol, cita:

los frailes agustinos que evangelizaban en Huamanchuco [...] decían que los indígenas de esa región, cuando se sentían enfermos hacían ofrendas a su huaca Antaguju y también 


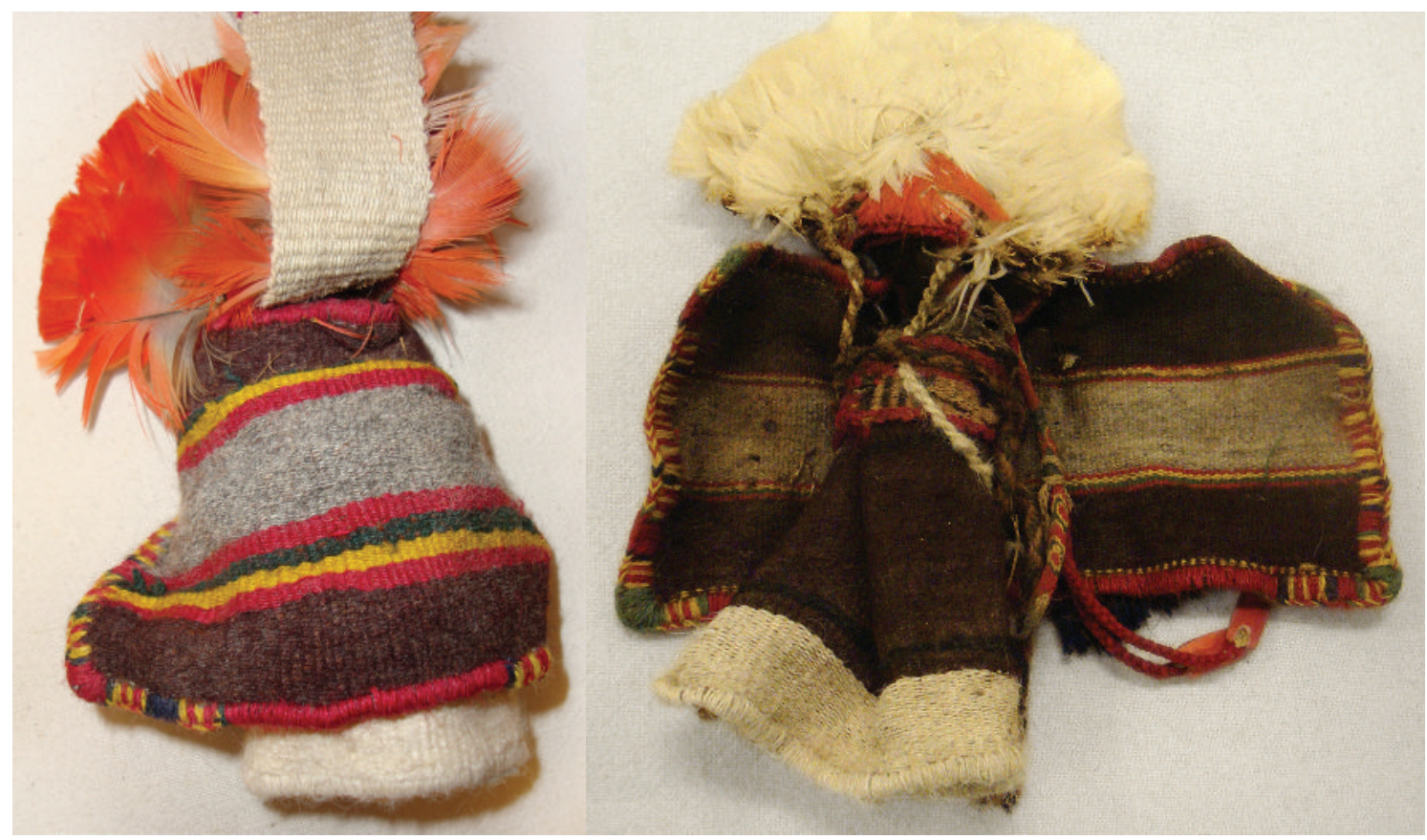

Figura 22. Tres listas de color teñido entre bandas y pampa de tonos naturales, en dos pequeñas lliklla (LL-99-014 y 016). Figure 22. Three color dyed lines between bands and natural color pampas on two small lliklla (LL-99-014 and 016).

al sol; pero para mochar a este último [...] embijábanse la nariz con sanco amarillo como cera, ques untarse con aquella color amarillo y en la cara con colorado [...] y esta es la señal que quieren mochar a el Sol (Agustinos 1557: 39, en Gentile 1999: 77).

Sugiriendo, además, que los colores rojo y amarillo relacionados con el culto al sol -provenientes posiblemente del más antiguo dios Con- el Inka los habría tomado de los cultos costeños (Gentile 1999: 80). Y aunque las capacochas se hubiesen ido complejizando a medida que las conquistas inkaicas avanzaban, en estas ceremonias estos dos tonos en relación mantuvieron su preferencia como uno de sus elementos principales.

Con los pallay de estos diseños en amarillo y rojo (luz solar) y el pallay más oscurecido del centro (penumbra), ¿no estamos ante una semiosis óptica de ese extendido relato mítico que ya hemos recordado y que persiste hasta nuestros días?

Evocar o recordar la conjunción de estos dos colores con otro menos luminoso, que no solo corresponde a un pasado mítico sino igualmente a la conjunción de las horas de pleno día con el atardecer y la noche, parece haber sido extraordinariamente importante. En las prendas provenientes del enterratorio de Llullaillaco, dos llikllas excepcionales, tejidas predominantemente en tonos naturales, sin dibujos, pero con angostas listas de color teñido separando las bandas de la pampa, repiten una alusión a esta estructura cromática.

Rowe da otros ejemplos de lliklla en miniatura, de otras capacochas, que siendo predominantemente en tonos naturales, llevan este mismo detalle (Rowe 1995-1996, fig. 19).

En la figura 22, correspondiente a prendas de Llullaillaco, aquella clasificada como 014 lleva amarillo y rojo, encerrando una lista verde muy oscura, que podría evocar los tiempos no luminosos. En la clasificada como 016 vemos la misma combinación de colores, aunque la lista verde oscura, muy angosta, que va después de la amarilla final, es difícil de percibir en la fotografía.

Incluso, es posible ver una repetición de esta semiosis, rojo, amarillo y otro tono menos saturado $\mathrm{u}$ oscurecido, coloreando el zigzag que va bordado en la parte inferior de los pequeños unkus (especie de camiseta larga) que visten figuritas masculinas. ${ }^{33}$

$\mathrm{Al}$ referirnos al cromatismo de los diseños, no es posible dejar fuera el espacio rojo en el que siempre van insertos estos pallay. Para distinguirlo más fácilmente lo hemos denominado "franja". Es interesante notar 


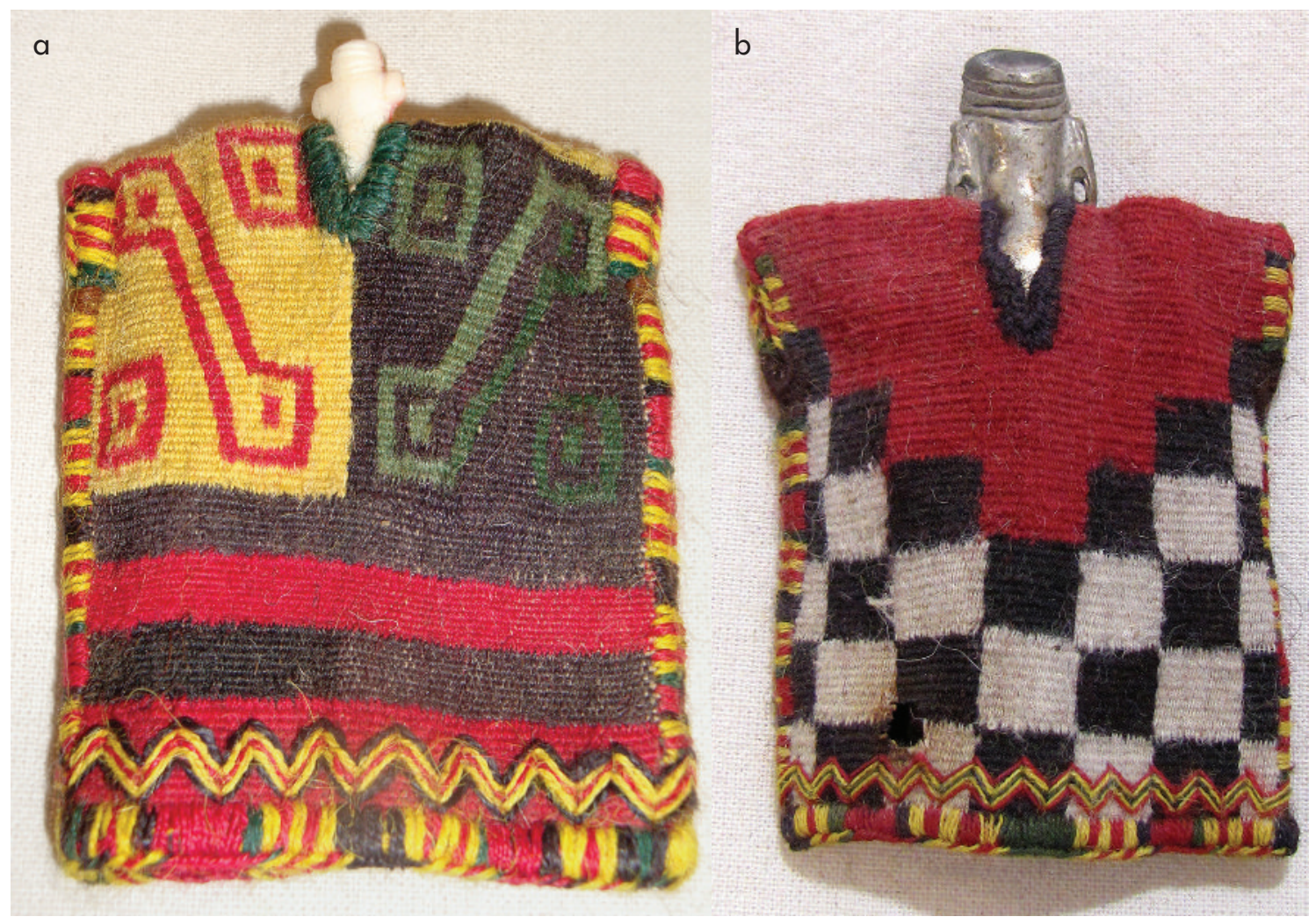

Figura 23: a) verde oscuro, amarillo, rojo, amarillo, verde oscuro en el zigzag que va en la parte inferior del unku con un diseño que J. Rowe bautizó como "llave inca"; b) rojo, amarillo, verde oscuro, amarillo y rojo, en el otro pequeño unku en damero. Notemos que la estatuilla masculina que lleva el diseño tan importante de la "llave Inca" no es de oro, como se podría pensar, sino de Spondylus (LL-99098 y LL-99-109). Figure 23: a) dark green, yellow, red, yellow, dark green in the zigzag running at the bottom of the unku, with a design J. Rowe called "Inca key"; b) red, yellow, dark green, yellow, and red on the other small checkered pattern unku. Note that the male figurine with the important "Inca key" design is not made of gold, as it might be assumed, but of Spondylus (LL-99-098 and LL-99-109).

que en estas franjas el tono se ha independizado del amarillo y del negro y parece valer por sí solo. Estos espacios son variables con relación al ancho que los determina. Al parecer, es el tono rojo, a veces oscurecido hasta un guindo, el que permite la inserción del pallay, antecediéndolo, encerrándolo. ¿Una alusión o señal de la presencia, en los diseños, del propio Inka -que llevaba borlas distintivas en este color- $y$ de las castas superiores del inkario a las que se les permitía el uso notorio de tonos teñidos y dibujos? ¿Una mención a las diferentes clases sociales aludidas en las vestimentas de estatuitas, unas en tonos kura (naturales), las otras en pana (teñidos), recordando las etnocategorías aymaras de los hilos para tejer?

\section{LA ICONOGRAFÍA}

\section{a) El zigzag}

En la conjunción de rasgos que conforman las imágenes tejidas en los pallay, hay un elemento organizador: el zigzag, siempre presente y estructurando la imagen. Innumerables líneas quebradas y en sucesión se encuentran decorando cerámicas, piedras, textiles de épocas precolombinas, pero nos detenemos únicamente en aquellas que coinciden en sugerir un encuentro y diferencia entre dos espacios cósmicos, dos épocas, dos mundos, ya insinuado por el cromatismo. ¿Por qué un zigzag atraviesa el rojo y amarillo y el rojo y negro en los colores de los rectángulos y ellos constituyen su contexto? Un trabajo extremadamente sugerente de Manheimm, en el quechua cusqueño tardío, nos 


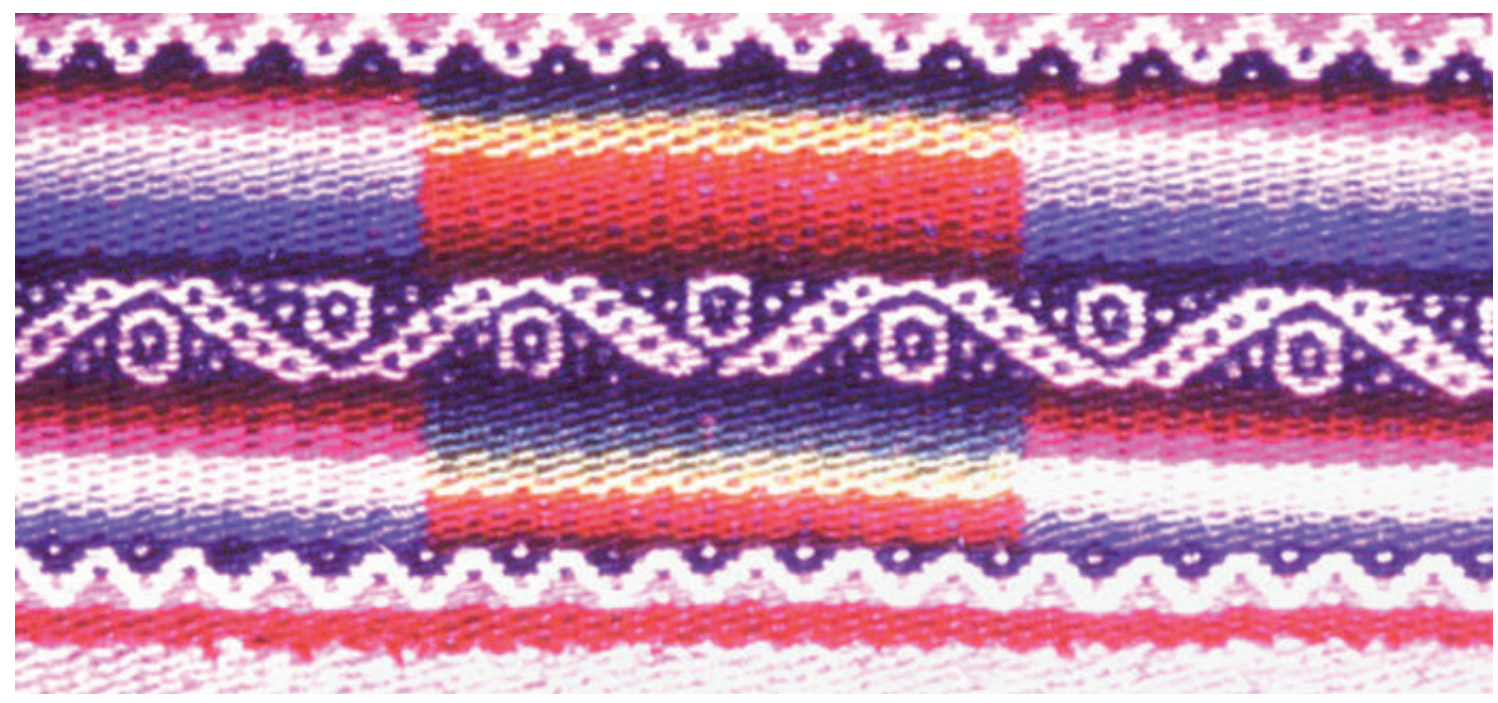

Figura 24. Taki nayra. Diseño del ayllu Isluga. Figure 24. Taki nayra. Design of the Isluga ayllu.

da algunas pistas para enfrentar este motivo de líneas rectas, inclinadas formando ángulos: "Q'iwi es una vuelta o recodo", incluso serpentear, "con su derivados q'iwiy 'torcer o dar vuelta' y q'iwi-q'iwi, 'zigzag"' (Manheimm 1991: 181-192).

Esta equivalencia con $q^{\prime} i w i$, abre un mundo de posibilidades semánticas, pues "en la cultura quechua el cambio es percibido como ocurriendo a través de un proceso de inversión”. Para él, q'iwi es como un garfio en un recodo con sus derivados q'iwiy: "to twist", dar vuelta y tiqray: "to reverse", volver de adentro hacia afuera. Traduce twist como una completa inversión. Y sugiere así que el zigzag compartiría estas ideas que surgen del serpentear (Manheimm 1991: 181-192).

¿Sería posible enfrentar el zigzag de los diminutos diseños como una transición entre dos realidades, un qiwi?

En el altiplano del norte de Chile, un diseño que se teje hasta hoy en algunas fajas, era conocido por las tejedoras del ayllu aymara de Isluga con un nombre muy sugerente: taki nayra, es decir, "camino con ojos". ${ }^{34}$

Esta nominación de taki nayra, que apoya la lectura de los círculos como ojos, es muy sugerente: incluye la idea de "camino" en las líneas quebradas, camino que sería muy especial o específico, ya que va en ángulos y no en línea recta. Un ritual presenciado en este mismo ayllu donde se tejían las fajas taki nayra (al menos hasta 1977, cuando dejamos Isluga) y donde las tejedoras nos aclaraban su sentido, parece confirmar esta posible correspondencia entre zigzag y camino ritual.
Estando en Semana Santa en Pueblo Isluga, capital central del ayllu, nos fue posible participar en la ceremonia que, luego de la muerte de Cristo, lo devuelve a la vida. Cuatro jóvenes disfrazados de diablos, ${ }^{35}$ sacaban el cuerpo de Cristo muerto, entrando y saliendo de la iglesia, desplazándose en zigzag y golpeando el suelo con pasos muy fuertes. Ellos habían levantado los clavos que lo sostenían a la cruz, de modo que piernas y brazos articulados, caían inertes. Luego lo llevaban sobre sus hombros en andas pesadísimas con techo de vidrio, donde parecía dormir. La ceremonia consistía en dar una sola vuelta por los cuatro altares que circundaban la iglesia, tan lentamente que la procesión durara desde la medianoche hasta el amanecer. Los diablos se iban deteniendo bruscamente en cada ángulo que marcaban enérgicamente con sus abarcas, toda la comitiva que iba detrás. Junto al lento desplazamiento de las andas, se avanzaba a penas entre los cuatro altares que rodeaban la iglesia y solo se descansaba al llegar a alguno de ellos. Es decir, el camino hacia la resurrección era muy tortuoso, difícil, y sometía a los portadores del cuerpo de Cristo a un agotamiento extremo. Un hombre dirigía esta ceremonia con un látigo, golpeando fuertemente a los diablos cuando querían apurar su paso. Los demás íbamos detrás con el mismo cansancio producto de caminar durante las horas de oscuridad (datos de campo de la autora, 1977).

Lo que quisiéramos destacar es que el largo camino ritual que definía el sendero entre la muerte y la nueva vida de Jesús -dos realidades distintas- era en zigzag, tal como en el diseño de la faja, no en línea recta, y en el ritual, muy duro de recorrer.

En los diseños de los aqsus y llikllas en miniatura ¿estamos, igualmente, frente a una idea de un desplazamiento ceremonial que une dos polos diferentes entre 
sí? Tal vez ¿una transición desde un mundo a otro, tal como lo eran los largos e intensos pasos ejecutados para permitir el regreso de Cristo a la vida? Tendríamos que considerar el zigzag no solo una forma de líneas quebradas, continuas, sino como un significante que puede expresar, en algunos contextos, una idea de transición entre dos realidades opuestas, posibilidad que se confirma en otros usos de esta forma.

Basta recordar el papel jugado por estas rectas quebradas en esos vasos de libación que son las paqchas precolombinas. Lothrop (1956: 9) definía estos recipientes como un vaso con un tubo en su base "con canales en zigzag en su superficie de arriba”. En los mangos que son a la vez el tubo por donde sale el líquido para beber, encontramos a menudo la forma del zigzag, cavada en la parte superior de su canal, y muchas veces, asociado con serpientes.

Y ¿qué es la libación? Es el contacto entre dos realidades distintas - una sagrada, la otra humana-, y el zigzag parece ser una forma óptica que promueve o facilita el paso entre una y otra.

El término paqcha (escrito como paccha o pajcha en otros trabajos) traduce una idea de salida de agua, un chorro, desde una cascada hasta una fuente. Allen describe que en una bella paccha del Museum of American Indian, entre los pies de los personajes que conforman el vaso, hay un pequeño agujero a través del cual un chorro de chicha podría haber circulado, "gentilmente", según ella, desde el vaso hacia el "canal cavado en la forma de un doble zigzag" (Allen (2002: 189). ${ }^{36}$ También aquí el contacto entre dos espacios o realidades que implica la libación toma la forma de líneas quebradas dispuestas en continuidad o de un doble zigzag.

Numerosos otros ejemplos describen estos zigzags en los canales-mangos de estas vasijas que pueden llevar diversas formas de personajes en su vaso contenedor. A menudo, las líneas oblicuas evocan directamente a una serpiente.

Otro ejemplo etnográfico confirma el uso de esta forma, igualmente en sucesión, para favorecer un trastoque o cambio. Stobart señala que el movimiento de los dedos de los músicos cuando alternan los tonos tapando los orificios de los pinkillos, entre los machas de Bolivia, se describe con el verbo link'u. Y este verbo remite no solo a los cambios de tonos sino, otra vez, al concepto de entrelazar. Aclarando el término "link'u", su informante: "tomó un palito y trazó en el suelo una raya en forma de zigzag, diciendo 'esto es q'iwi, es lo mismo que link'u"; y luego, Stobart traduce la expresión de su acompañante "sumaq link'u" como "esto está bien ligado o conectado" (Stobart 2014: 584).

El zigzag es tan importante en las vestimentas de las figuritas de altura que se presenta, en otros contextos, más allá de chumpi, lliklla o aqsu. Así, desde el atuendo de plumas en la cabeza de las estatuitas femeninas (fig. 25), cae, por detrás, una estola que es difícil de ver en las fotografías. Las plumas que se continúan desde el gorro por la espalda y encima de esta tela, la cubren. No se trata, sin embargo, de un paño que solamente protege a las plumas del contacto con el cuerpo, tiene su propio pensamiento. En la parte baja lleva bordado, sin primor alguno, un zigzag.

Es un detalle que podría parecer simplemente decorativo si no fuera por la necesidad de la presencia de las líneas quebradas. Y, también, un zigzag va en los unkus en miniatura que visten las figuritas masculinas, en este mismo tipo de capacocha. Este bordado, ubicado hacia el ruedo de abajo de estas prendas, es visible en la figura 23. Fue posible notar, igualmente en él, que comparte los tres tonos, dos más luminosos, uno más oscurecido, que se pudo sacar a luz en el análisis del cromatismo. ¿Cuál es la necesidad insistente de esta figura quebrada, pero en sucesión?

Las líneas formando ángulos, han sido interpretadas en varios trabajos anteriores como la presencia o evocación al rayo (Dranzart 1995, Hoces de la Guardia \& Rojas 2013, 2016a, 2016b). Si bien el rayo representa un ejemplo de contacto -mundo de arriba y mundo de abajo (este mundo)- su mención no cubre todo el semantismo más complejo de trastoque, inversión, paso o conexión, que pueden evocar estas líneas del zigzag. Otro párrafo de Stobart niega que el movimiento de los bailarines en la danza llamada wayli, marcando fuertemente un zigzag, sea una forma siempre asociada al fenómeno celeste, pues "la trayectoria en zigzag del baile se compara con una víbora", y al preguntar si esta danza era comparada con el rayo, lo negaron (Stobart 2014: 592).

En el cromatismo de los diseños se sugería la posible presencia de dos estados del mundo, uno anterior sin sol y otro posterior con luz solar, que marcaría ya la presencia del Estado Inka. ¿El zigzag estaría señalando la relación de transformación de uno en el otro? No solamente recordando una historia mítica en imágenes sino, tal vez, sugiriendo que este enlace sería imperioso para la identidad del Tawantinsuyu. Este tema, presente siempre en los vestuarios femeninos de altura, destaca 


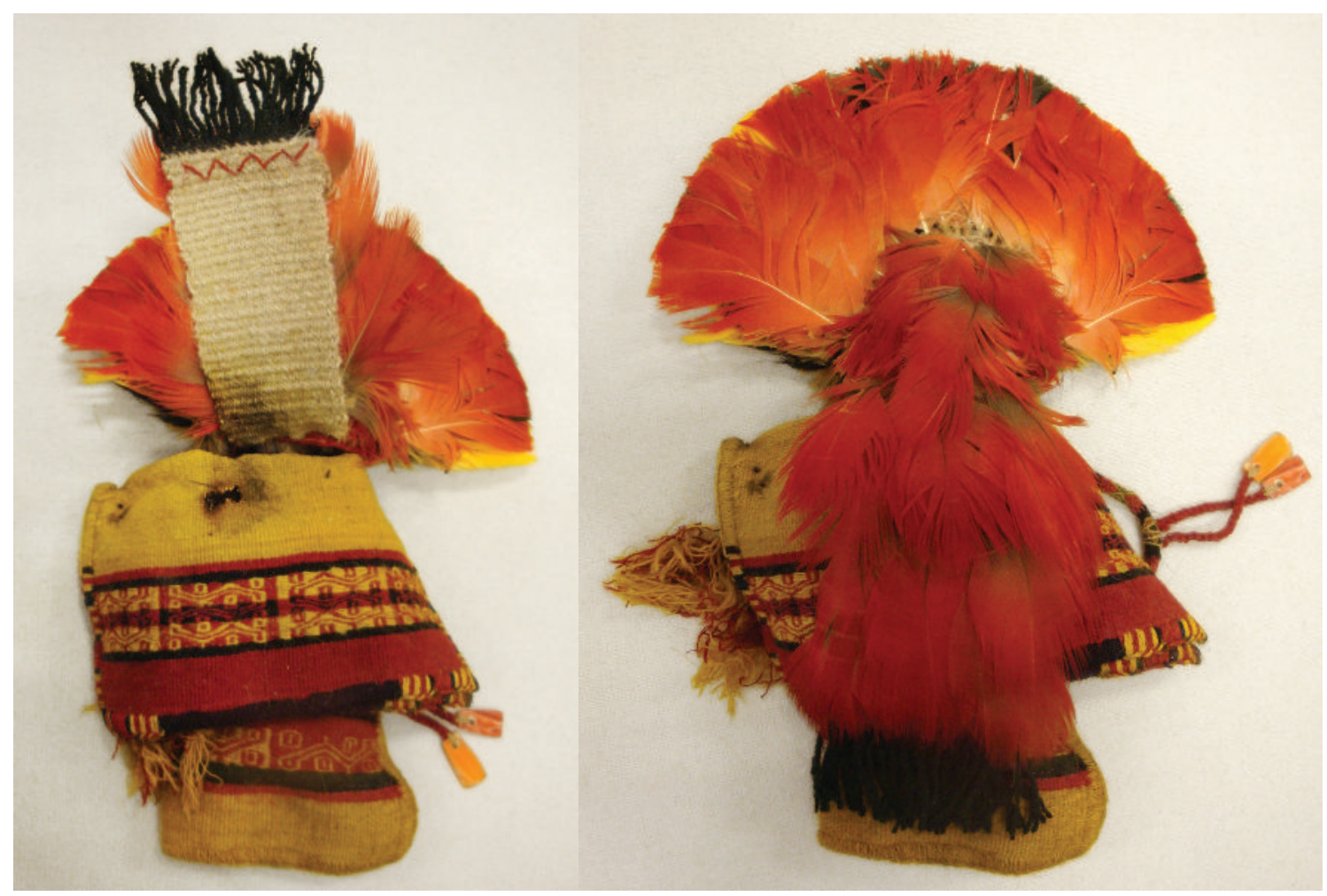

Figura 25. Atuendo de plumas cayendo por la espalda, bordado de zigzag en rojo sobre el blanco de la estola (Llullaillaco 99-015). Figure 25. Feather garment falling down the back, with red zigzag pattern embroidery on the white of the stole (Llullaillaco 99-015).

de una manera propia, casi obsesiva, la trascendencia que tenía en el pensamiento inka la idea de conexión -de carácter reversible y tal vez frágil- entre mundos opuestos o situaciones contrastantes, cósmicas, sociales, tal vez, incluso, de conciencia.

\section{b) Las serpientes (amaru, en quechua)}

El universo de imágenes de serpientes en la iconografía precolombina es muy extenso, como, también, lo son las muchas referencias a ellas en textos ya coloniales de los cronistas. Entre esta profusión de datos, intentamos captar a este ícono tal como está tejido en los diseños de las vestimentas de las figuritas de altura, con dos cabezas, pero integrado a un doble contexto: al zigzag que define su cuerpo y a los colores amarillo y rojo o rojo y negro que lo van definiendo, es decir, posiblemente vinculado a grandes acontecimientos de transformación.

A solas, sin que podamos suponerla bicéfala ni iluminada con esos tonos especiales, surge, en diferentes relatos, en los momentos en que algo cambia de manera trascendente. Mencionando solo algunos, recordemos, por ejemplo, la visión que tiene el Inka Tupaq Yupanqui, en la fuente de Susurpuquio, de un personaje con serpientes en los brazos y la espalda, antes de que él inicie las grandes reformas que crearán al Tawantinsuyu.$^{37} \mathrm{Es}$, también, el enorme amaru, serpiente tipo dragón que aparece justamente en la época de ese Inka, según relata Santa Cruz Pachacuti y cuyo nombre el Inka le concede a su heredero, Tupaq Amaru; las serpientes que devoran el techo de la lujosa casa de Tantañanca en momentos en los que, justamente, están naciendo nuevas deidades (¿Tomás? 2008: 43-519).

¿Presagios de trastornos simbolizados en la presencia de las serpientes? O, tal vez, ¿participación directa de ellas en esos cambios como un símbolo de enlace entre distintas realidades? Parecen atraer, también, el advenimiento de nuevas situaciones como lo sugieren los nombres Amaru y Katari (serpiente en aymara) utilizados por los líderes indígenas de las grandes rebeliones, ya coloniales, de fines del siglo xviII, que buscaban un nuevo vuelco del mundo, un nuevo pachakuti. 
Los trabajos de algunos investigadores han destacado este mismo vínculo semántico que pueden conllevar las serpientes completando el trabajo del zigzag, tal como señala Zuidema (1983: 39) cuando relata que "el puma está asociado con lugares de transición o transformación. El puma comparte este rasgo con otros animales como el amaru [...] con estados o momentos de transición". Por su parte, Allen (2002: 199) reitera que "podemos leer la serpiente amaru como marcando el actual proceso de transición [...] el motivo del felino-serpiente significa el contacto y transición entre dos estados opuestos".

Hay imágenes de serpientes con sus cuerpos quebrados, muy anteriores al Inkario. En su trabajo, Paul (1982: 55-59), entre muchas otras ilustraciones de serpientes bordadas en los textiles Paracas, muestra dos que son zigzagueantes. El bordado permite perfectamente las curvas, de modo que este rasgo ha sido establecido en forma voluntaria. Tampoco la inclinación que ellas llevan en el pallay de vestimentas femeninas en los enterratorios de altura se debe al hecho de que, en este caso, sea la técnica texti ${ }^{38}$ la que impida hacer las curvas características de este ofidio; no pueden lograrse de manera tan perfecta, pero sí insinuar un ondulado. ${ }^{39}$ El zigzag ha sido elegido por quienes crearon el modelo, como un significante de importancia.

Es interesante notar que, en algunas ocasiones, zigzag y serpientes parecen tanto coincidir como alternarse. O incluso, llevar un mismo contenido semántico. Es el caso de los canales cavados en muchas paqchas cuando las líneas quebradas terminan en cabezas opuestas. Igualmente, nos encontramos con esta alternancia en los diseños de las vestimentas de figuritas de altura.

Refiriéndose a una paqcha, Allen (2001: 193) da una extraordinaria trascendencia a la imagen serpientezigzag: "Los dos lados del mango están decorados con una zigzagueante serpiente de dos cabezas".

Sugiriendo que el zigzag puede ser "leído" como una serpiente sobrenatural, conectada, en este caso concreto, con la selva tropical, con sucesos de guerra, y con muertos fertilizadores, pero teniendo un punto de partida en la Sierra (Allen 2002: 193). Para Allen, este tipo de enlace entre contrarios (arriba y abajo, pero, también, interior y exterior, entre otros), estarían conformando un sistema dinámico, de naturaleza reversible. Y relacionado, directamente, con el diseño de las vestimentas de altura: "Cuán claramente este principio

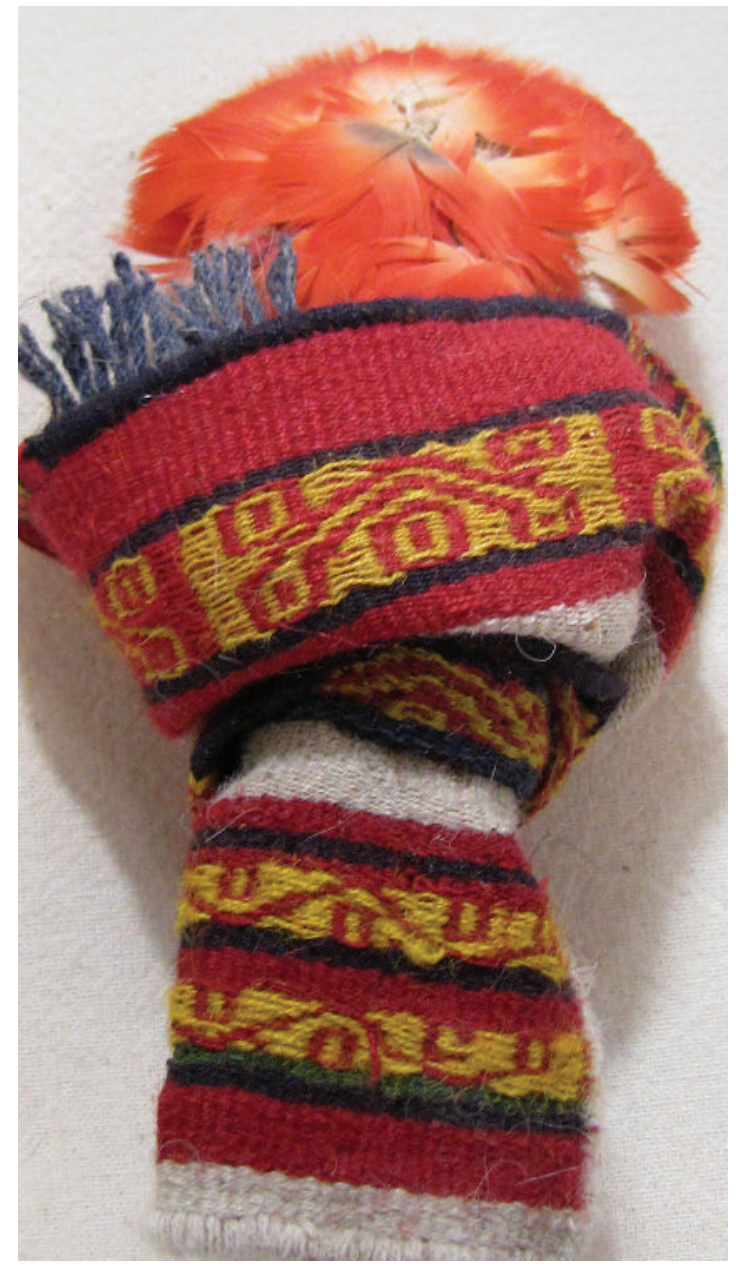

Figura 26. Serpientes y ojos en la lliklla. En el aqsu, zigzag continuo. Listas generalmente en negro, pero también en otros tonos, siempre enmarcan y destacan el pallay (Lullaillaco 99-054). Figure 26. Snakes and eyes on the lliklla. Continuous zigzag on the aqsu. Lines usually in black, but also in other shades, always framing and highlighting the pallay (Lullaillaco 99-054).

dialéctico encuentra expresión en la iconografía andina: en el amaru de dos cabezas, a la vez felino y serpiente, cuya cabeza es la cola y que succiona agua en cada dirección" (Allen 2002: 199).

El tema del diseño de los vestuarios en las figuritas de altura, por su cromatismo, su asociación zigzagserpientes y por las dos cabezas opuestas, destaca, de una manera extraordinaria, la importancia que en el pensamiento inka tenía el enlace -de carácter reversible y tal vez frágil- entre mundos o situaciones contrastantes, cósmicas, sociales, incluso, quizás, entre estados del ánimo y la mente. 


\section{c) Los “ojos"}

¿Por qué podríamos considerar como ojos a los círculos que acompañan a las serpientes? Hemos señalado que ya han sido llamados así por diferentes estudiosos. Hay numerosos ejemplos de diseños que conllevan círculos, a solas, no solamente en textiles, sino también en cerámica de épocas precolombinas. ¿De qué hablan? No van de a dos, sino de a uno o formando conjuntos que recuerdan, inevitablemente, los ojos representados en el conocido dibujo de Santa Cruz Pachacuti, del altar del templo de Coricancha. El cronista define estos círculos como ñawi, en el texto que los acompaña: "Ymaymana ñaoraycuna ñauin". Itier traduce esta frase como "los ojos de la diversidad de todas las cosas" (Santa Cruz Pachacuti 1993: 110). Pero son representaciones coloniales.

En los textiles étnicos actuales de Bolivia, hay figuras que las tejedoras llaman, igualmente, ñawi. Corresponden, por lo general, a rombos más que a formas redondas, difíciles de tejer cuando los hilos son menos finos y menos densos. $\mathrm{O}$, tal vez, a una equivalencia entre estas dos formas heredada desde lejos. Encontramos, sin embargo, círculos en el diseño de las fajas del ayllu Isluga, que citamos anteriormente, que eran llamados "nayra", ojos en aymara (fig. 24). Los rombos designados como ñawi en quechua y los círculos nayra, en aymara, no parecen aludir, sencillamente, a los ojos de una cara, animal o humana. No son dos, como se esperaría, y a veces en los textiles se repiten conformando verdaderas guardas de sucesión continua. En los diseños de los trajes de las figuritas de altura se juntan en diferentes cantidades.

Abercrombie reúne en un solo párrafo el sentido que tendrían estos ojos tejidos en vestimentas actuales del ayllu K’ulta: "Los ojos textiles recuerdan el generalizado concepto andino de paqarina... orificios de la tierra por donde salieron los antecesores en los pasados precolombinos narrados" (Abercrombie 2006: 241).

Recordando también la idea de camino -traslado o conexión entre un punto y otro- expresada en los zigzags del taki (camino en aymara) nayra de las tejedoras de Isluga:

No debería, pues, sorprendernos que las franjas de diseño textil sean también un tipo de thaki ("senda"), a menudo de forma zigzagueante. Cabalgando en estos zigzag de las telas tanto precolombinas como modernas, están los frecuentes elementos de diseño llamados layra ("ojo"), ${ }^{40}$ que quizás sirven de portal mnemónico al submundo y al pasado, que a veces se lo llama layra timpu ("tiempo del ojo") (Abercrombie 2006: 241).

Esta sugerente referencia etnográfica sitúa los círculos estableciendo una doble relación: con lo anterior -que en el idioma aymara está ubicado hacia adelante, en la dirección hacia la que miran nuestros ojos- de modo que nayra es, también, pasado; y luego con lo interior y profundo: el "submundo". Muertos y antecesores se sitúan en ese espacio y los círculos serían un punto tanto de tránsito como de conexión con él. Como lo expresa Abercrombie (2006: 243): "el simbolismo de los ojos apuntando hacia el tiempo del ojo originario".

Una extraordinaria conjunción de lugares y tiempos se estaría dando en los pallay de los pequeños trajes de las figuritas. Esta coincidencia visual y semántica entre tejidos separados por una larga distancia, K'ulta en el norte de Potosí, Bolivia, e Isluga en el altiplano de Chile, hace pensar que el diseño de las vestimentas de las estatuillas en las capacochas -en su forma más simple, solo zigzag y ojos- ha permanecido por más de quinientos años conservando algo de su más complejo $\mathrm{y}$ antiguo significado.

\section{EL DISEÑO COMO UN CONJUNTO DE RASGOS}

Este patrón tejido es tan especial y recurrente en las capacocha, que se repite, también, en una prenda, la chuspa, que llevan las estatuitas masculinas. El vestuario masculino está compuesto por tres prendas principales: su unku (quechua), o qhawa (aymara), una especie de camisón largo hasta las rodillas; una llakolla, manta superpuesta que, por lo general, envuelve toda la figurita con un cordón que la ata al cuerpo impidiendo ver el unku, y una ch'uspa (bolsita para la coca) que cuelga del hombro derecho. En algunas de estas ch'uspas podemos observar un pallay que se asemeja al de las prendas femeninas. Puede alternarse en las ch'uspas de capacocha con otro más abstracto, pero, en los ejemplos que conocemos, es el más recurrente. A veces es difícil reconocerlo, porque las rectas que unen a las serpientes, como sucede en la figura 27a, lo hacen aparecer, más bien, como una forma gráfica abstracta. Pero en esta forma menos sensual, lo tenemos también presente en algunas lliklla de miniaturas femeninas de altura. Sería intercambiable. 
a

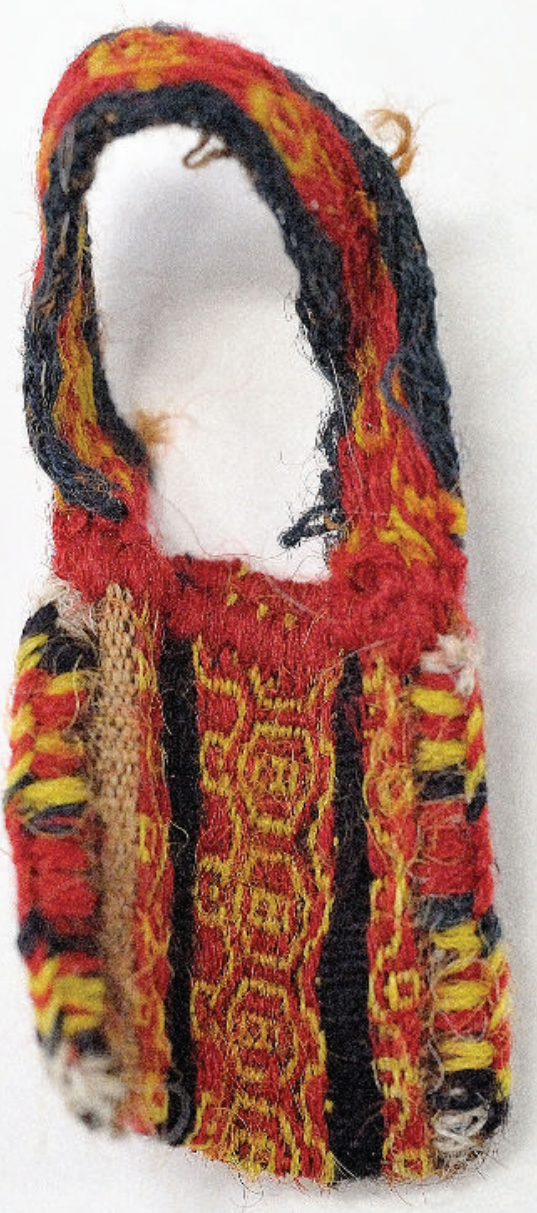

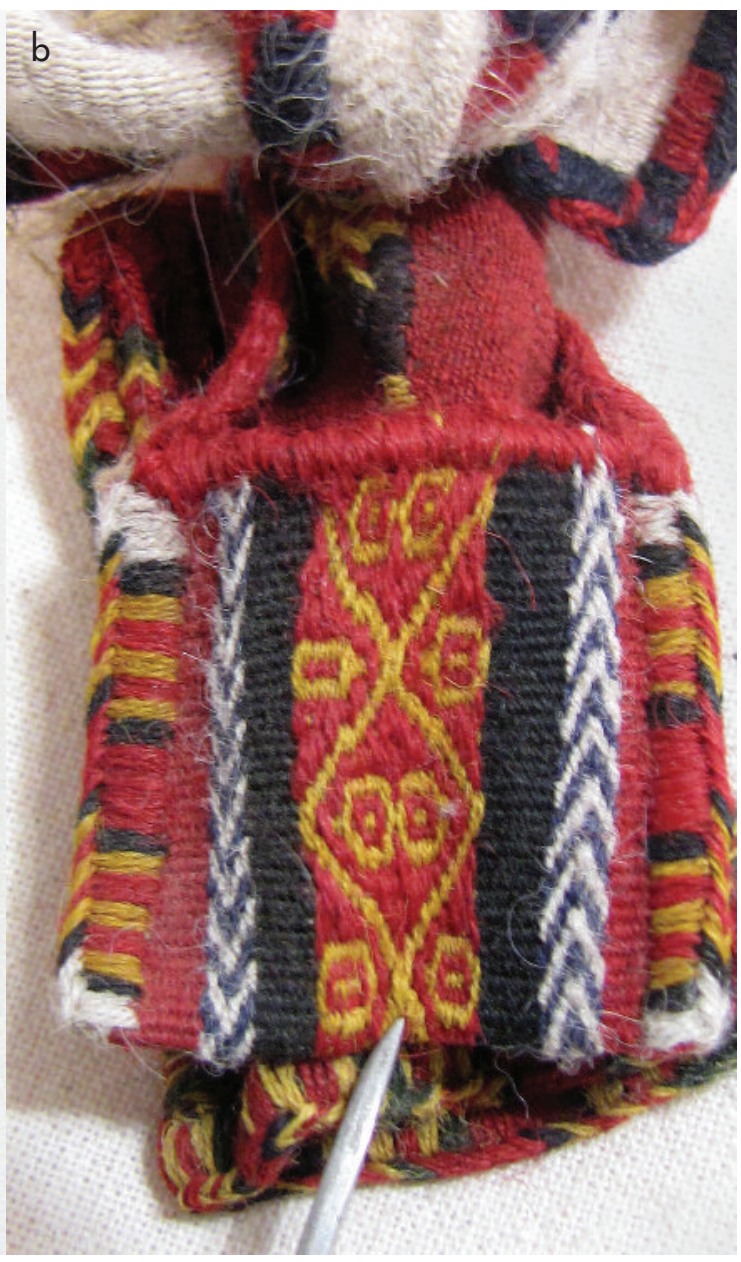

Figura 27. Ch'uspa (prenda masculina). Llevan un diseño con una matriz semejante al que va en aqsu, lliklla y chumpi, en el vestuario femenino: a) Llullaillaco 99-110. El cuerpo de las serpientes evocado con dos rectas, más los enlaces que las unen, le restan su aspecto figurativo; b) LL-99-090. Figure 27. Chiuspa (male garment). Their pattern has a mold similar to the one in the aqsu, lliklla, and chumpi on the women's clothing: a) Llullaillaco 99-110. The snakes' body evoked with two lines plus the links that join them together, which diminish their figurative aspect; $\boldsymbol{b}$ ) LL-99-090.

Muchas ch'uspas provenientes de diferentes sitios arqueológicos, no necesariamente capacocha y de tamaño normal, fueron tejidas con este grafismo (Rowe 1995-1996: fig. 4 y 5).

Sin embargo, Gentile (2017: 148) hace una interpretación propia y diferente para este diseño no bien icónico (fig. 27a): los hexágonos que contienen dos cuadrados con sus salientes laterales son "el logotipo de un rostro humano visto de frente", que corresponde a cabezas cortadas, dispuestas en hileras verticales. Serían semejantes a las representadas en el Paramento del templo de Sechín, en Casma, Perú. El dibujo de Tello que ella reproduce tiene, en verdad, un extraordinario parecido con el diseño de las ch'uspas mencionadas. Se trata, no obstante, de un tema tan diferente. Sería muy difícil pensar que la pertenencia interna de los diseños en las pequeñas vestimentas de altura se quiebra para hablar de enemigos vencidos en alguna batalla. Más aún, si volvemos a observar los pallay, por ejemplo, el de las bolsitas en la figura 27, e imaginamos una recta que los separe verticalmente en dos, los ojos dejan de parecer los de un rostro y el dibujo se convierte en el de zigzag y círculos simples tan repetitivo. El diseño más abstracto que va en aqsu o ch’uspa masculinos es, además de otros semantismos en contextos muy diferentes, el desdoblamiento de esa imagen más sencilla. 

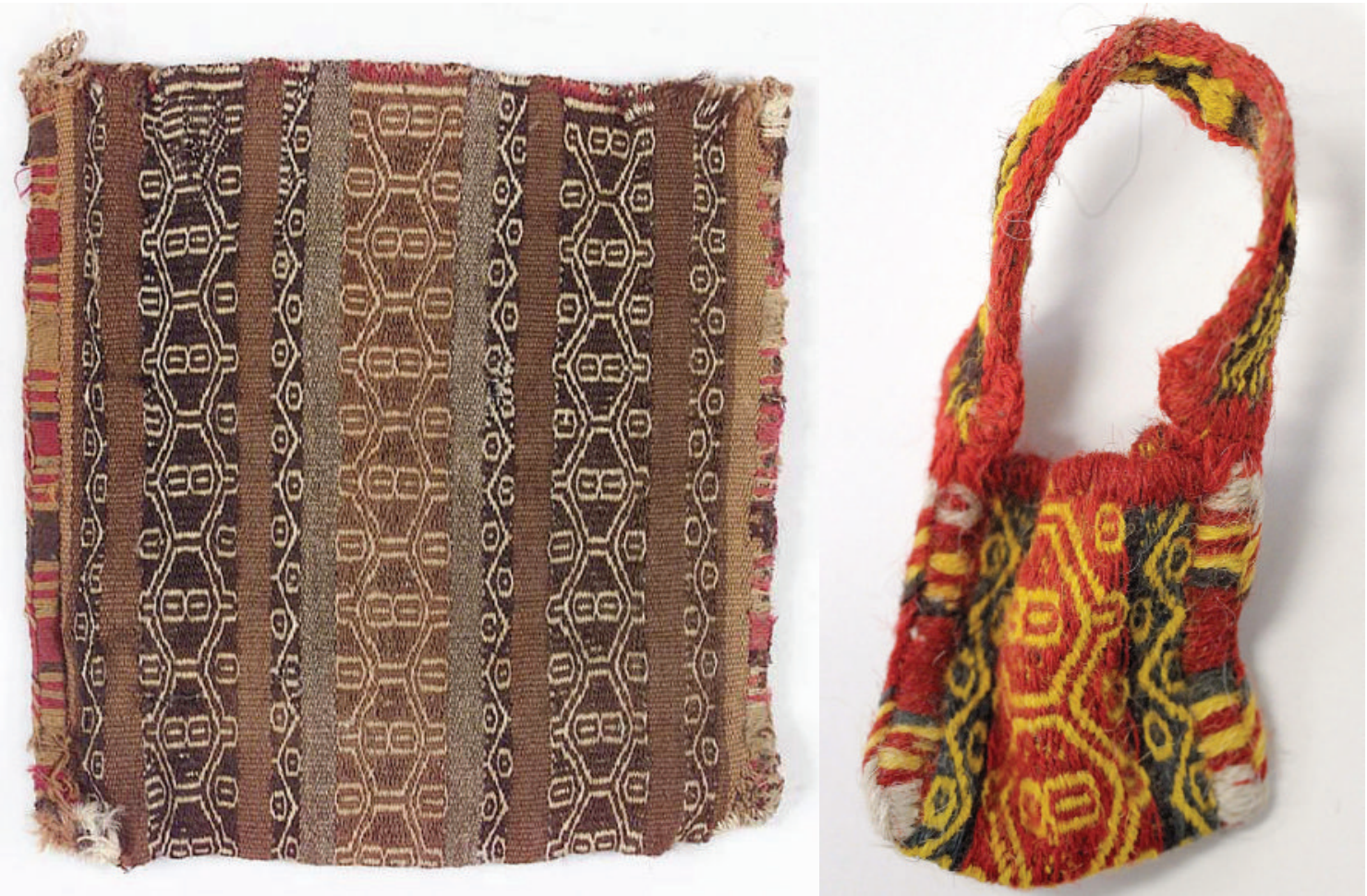

Figura 28. Otra ch'uspa con el mismo diseño muy semejante a la ch'uspa de Llullaillaco (fig. 27a), pero sin el cromatismo propio de los diseños de altura (MNAAH del Perú, en Paulinyi 2018: s/p.), en un enterratorio que no corresponde a una capacocha (Azapa 15, Arica). ${ }^{41}$ En esta bolsa, un diseño más simple de zigzag con ojos enmarca al más complejo, lo mismo que ocurre en la ch’uspa de Lluillaillaco 99-083. ¿Una equivalencia entre grafismos que podríamos interpretar en aquellos de capacocha, que agregan amarillo y rojo, como una mayor complejidad del mensaje? Figure 28. Another ch'uspa with the same pattern and very similar to that of the Llullaillaco ch'uspa (fig 27a), but without the use of color typical of the high-altitude patterns (MNAAH del Peru, in Paulinyi 2018: n.p.), in a burial site that does not belong to a capacocha (Azapa 15, Arica). In this bag, a simpler zigzag pattern with eyes frames a more complex one, like in the Lluillaillaco ch'uspa 99-083. Is this a case of equivalence between graphic designs that can be interpreted as greater complexity of the message in the capacocha ones, which add yellow and red?

En estos casos, es interesante observar la reutilización parcial de significantes. En las pequeñas vestimentas se ha añadido, a las representaciones lineales, un cromatismo particular, y de este modo expresan, además de lo inscrito en líneas y figuras, cambios de luces entre épocas, entre lo claro del día y lo oscuro de la noche, con todos los seres que los pueblan. Y esta conjunción particular de grafismos y colores parece ser propia de los textiles de capacocha.

Íconos de amaru en zigzag y ojos, aunque con otra organización, están también presentes en esa prenda tan importante que es el unku masculino, como se observa en la figura 23. Un detalle que ya han señalado otras investigadoras (Rowe 1995-1996, Phipps 2004), al abordar las camisas que llevan los hombres en las estatuillas. En las prendas varoniles, este diseño corresponde a la figura de un tocapu, el que para Gentile estaría relacionado con el nacimiento de Amaru Topa Inka. ${ }^{42}$ Recordaría, igualmente, el surgimiento de una nueva era al estar vinculado a los cambios transformadores de Pachakuti, pero con su propio contenido. Aunque esta síntesis de íconos de serpientes y ojos es compartida entre estatuillas femeninas y algunos unkus masculinos, muchas diferencias separan a estos dos textos visuales: en los pallay no hay presencia de estructuras duales y cuadripartitas, ni de organizaciones en diagonal, como sucede en los tocapus. Los diseños en "llave inca" no serían una condensación del mismo tema desarrollado en los diseños de las vestimentas femeninas en miniatura. Sin embargo, podemos notar que en ellos se repite la oposición cromática que va tejida en algunos pallay en los cuadrantes del tocapu: amarillo y rojo en 


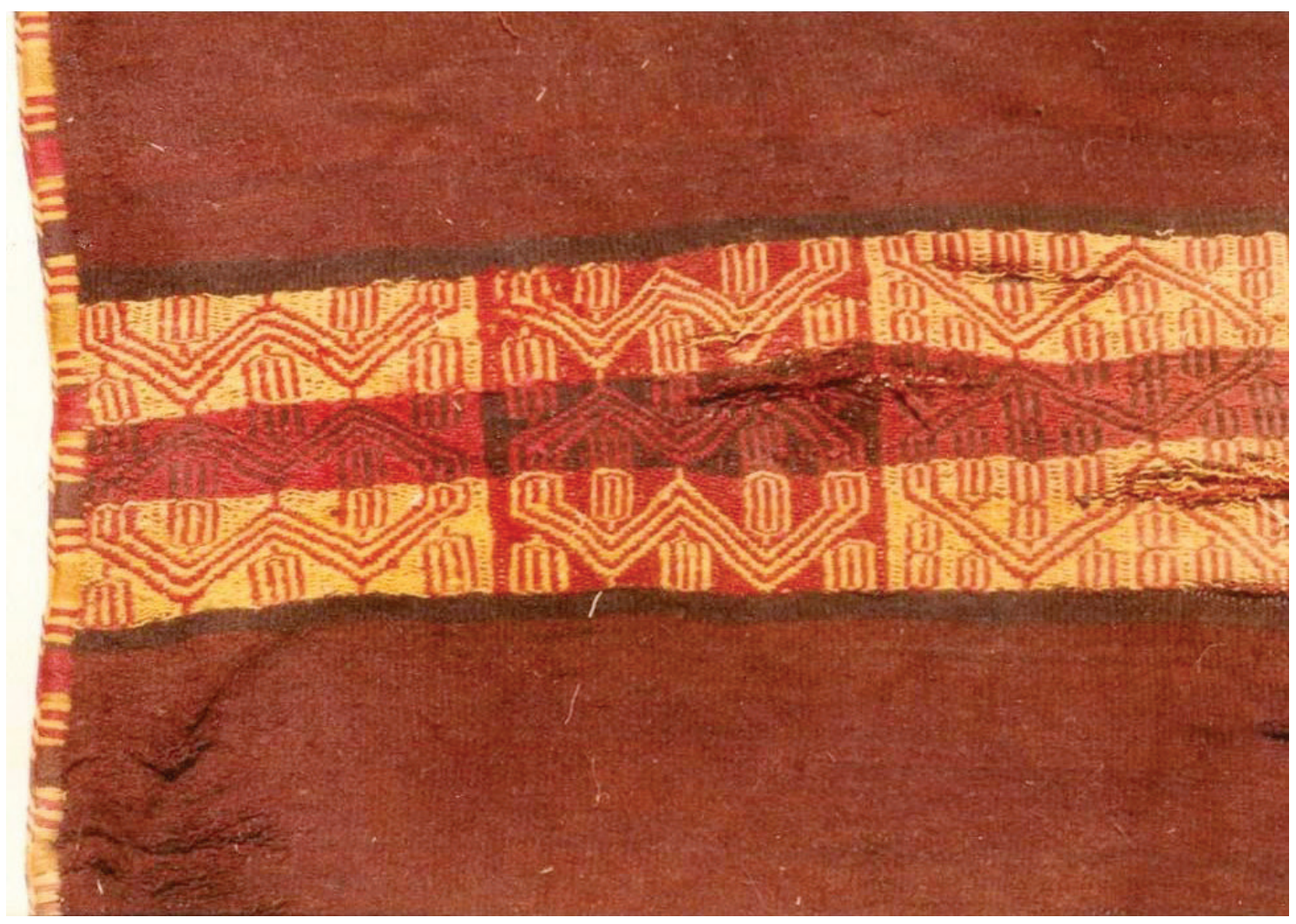

Figura 29. Vista parcial de una lliklla, cerro Esmeralda. (Fotografía: gentileza del Museo Regional de Iquique). Figure 29. Partial view of a lliklla, Esmeralda Hill. (Photograph: courtesy of the Museo Regional de Iquique).

unos; en los otros, tonos oscurecidos que dificultan la percepción de las serpientes. ¿La figura inscrita en el cuadrante de ese tipo de unkus estaría representando al propio Tawantinsuyu, mientras, tal vez, el diseño en los vestuarios de las figuritas femeninas aludiría, a la necesidad de proteger el Estado Inka? Más adelante volveremos sobre esta sugerencia.

\section{EL FORMATO MAYOR}

Tuve la oportunidad de observar la colección de textiles del enterratorio del Cerro Esmeralda, en Iquique, Chile, justo cuando fue entregada al entonces Museo de la Universidad del Norte, en 1975 (hoy Museo Regional de Iquique). Estas ofrendas fueron desenterradas tan solo a 900 metros, pero "en un monte que se yergue como el más elevado en el nudo cordillerano frente al mar" (Checura 1977: 140).
Los restos encontrados en la cumbre del cerro Esmeralda permanecieron en muy mal estadolos primeros años que estuvieron depositados en el Museo; era posible fotografiar solo trozos de textiles que sobresalían del confuso bulto que contenía las ofrendas mortuorias. Aun así, era posible distinguir el inicio de un diseño común a algunas de las prendas de tamaño mayor: fueron ellas, ya en ese entonces, las que, por su pallay tan amplio e icónico, me llamaron poderosamente la atención. Posteriormente, han sido descritas como siendo un conjunto extraordinario de 10 aqsus y 11 llikllas que acompañaban los cuerpos enterrados de una muchacha y una niña. ${ }^{43}$

En esos años, el estado delicado de las vestimentas no permitía extenderlas completamente. Aun así, fue la imagen tan especial de las serpientes bicéfalas acompañadas con figuras que podían evocar ojos, la que conservé en mi memoria y la que me volvió a atraer poderosamente al reencontrarla en miniatura en las vestimentas de las figurillas exhibidas en el Museo Arqueológico de Alta Montaña, en Salta. 


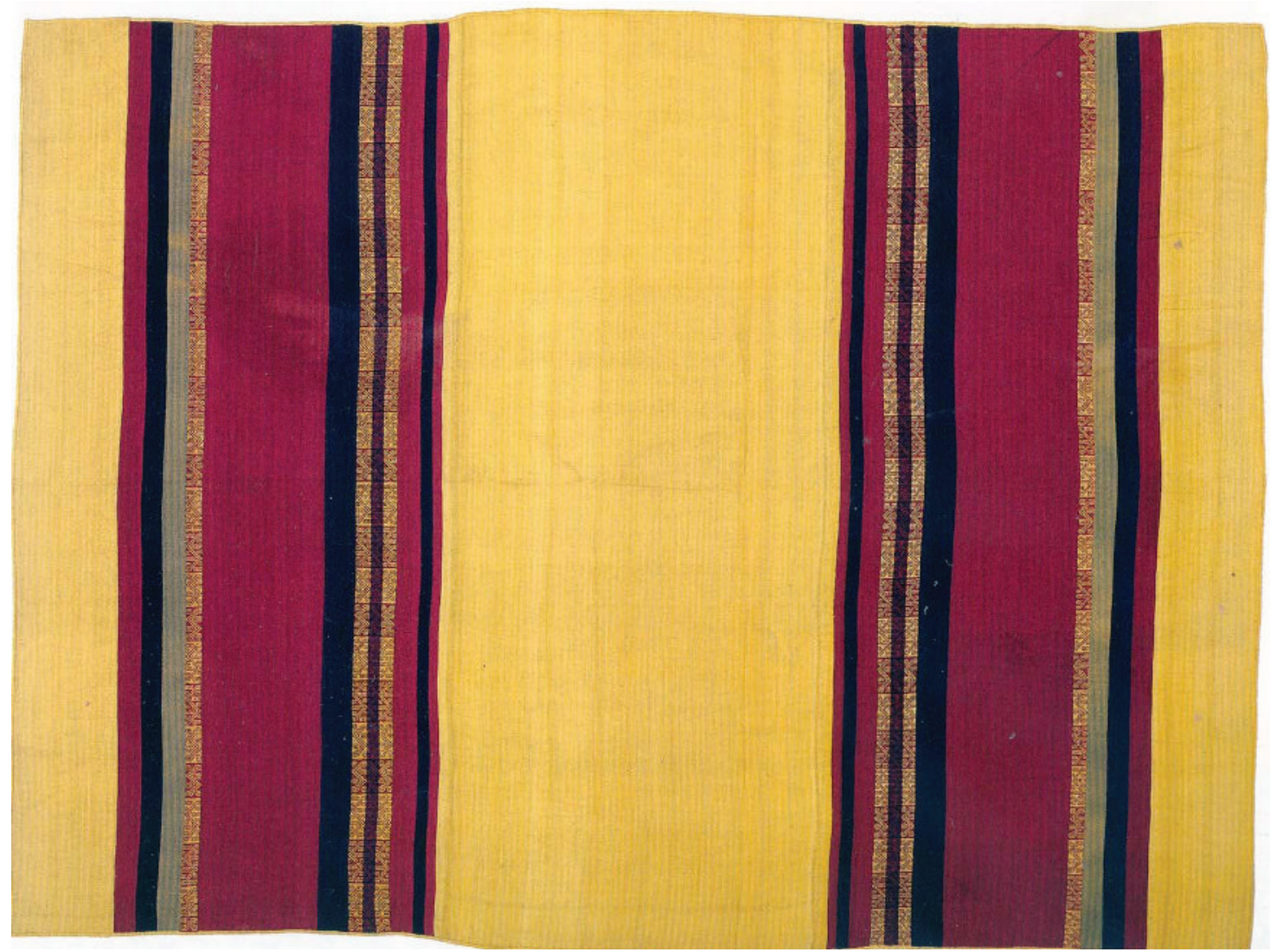

Figura 30. Lliklla de un enterratorio en Pachacamac (Phipps et al. 2004: 131). Lleva pampa amarilla, como las que van en algunos diseños de las pequeñas vestimentas. Figure 30. Lliklla from a Pachacamac's burial site (Phipps et al. 2004: 131). It has yellow pampa, like those on some patterns of the small clothes.

Era impresionante la similitud del diseño de esas prendas de cerro Esmeralda con aquellos que estaban tejidos en los trajes en miniatura. Y no únicamente los rectángulos, serpientes, ojos y colores, sino también la coincidencia de detalles: la franja con tres guardas de dibujos, proveniente de cerro Esmeralda (fig. 29), lleva la interior más oscura, al igual que en los pallay diminutos. $Y$ en esas prendas en tamaño mayor, serpientes más anchas, diseñadas con tres rectas, llevan un solo círculo en los ángulos dejados por el zigzag, mientras que las serpientes definidas por solo dos trazos permiten la inclusión de una mayor cantidad de ojos. Estábamos ante la existencia de un mismo pallay, aunque en distinto tamaño: ¿Una matriz significante de trascendencia indudable relacionada con niñas, niños y adolescentes sacrificados?

Varios otros aqsus y llikllas en gran formato, han sido encontrados o desenterrados de otras capacochas.
Phipps et al. (2004) ilustran dos llikllas en muy buen estado de conservación, cuyos diseños se asemejan a los de las llikllas y aqsus de cerro Esmeralda. Una de ellas proviene del sitio de Pachacamac, en el "Cementerio de las Doncellas” excavado por Max Uhle.

A pesar de mínimas diferencias -en el ejemplo anterior algunas listas negras no van cercando directamente al pallay, sino que un poco alejadas de él-, se trata de una misma porpuesta óptica y táctil.

En este nuevo ejemplo (fig. 31) es posible notar que la lliklla tiene un estilo propio -ojos más rectangulares- que no hemos encontrado en las prendas en miniatura. ¿Mayores libertades en la mano de obra en esos textiles de gran formato? La repetición de estos trajes en diferentes tamaños no puede dejar de impresionarnos por la gran trascendencia que debieron tener los diseños que los definen. Otra lliklla de tamaño mayor encontrada en la capacocha de Ambato, Perú, 


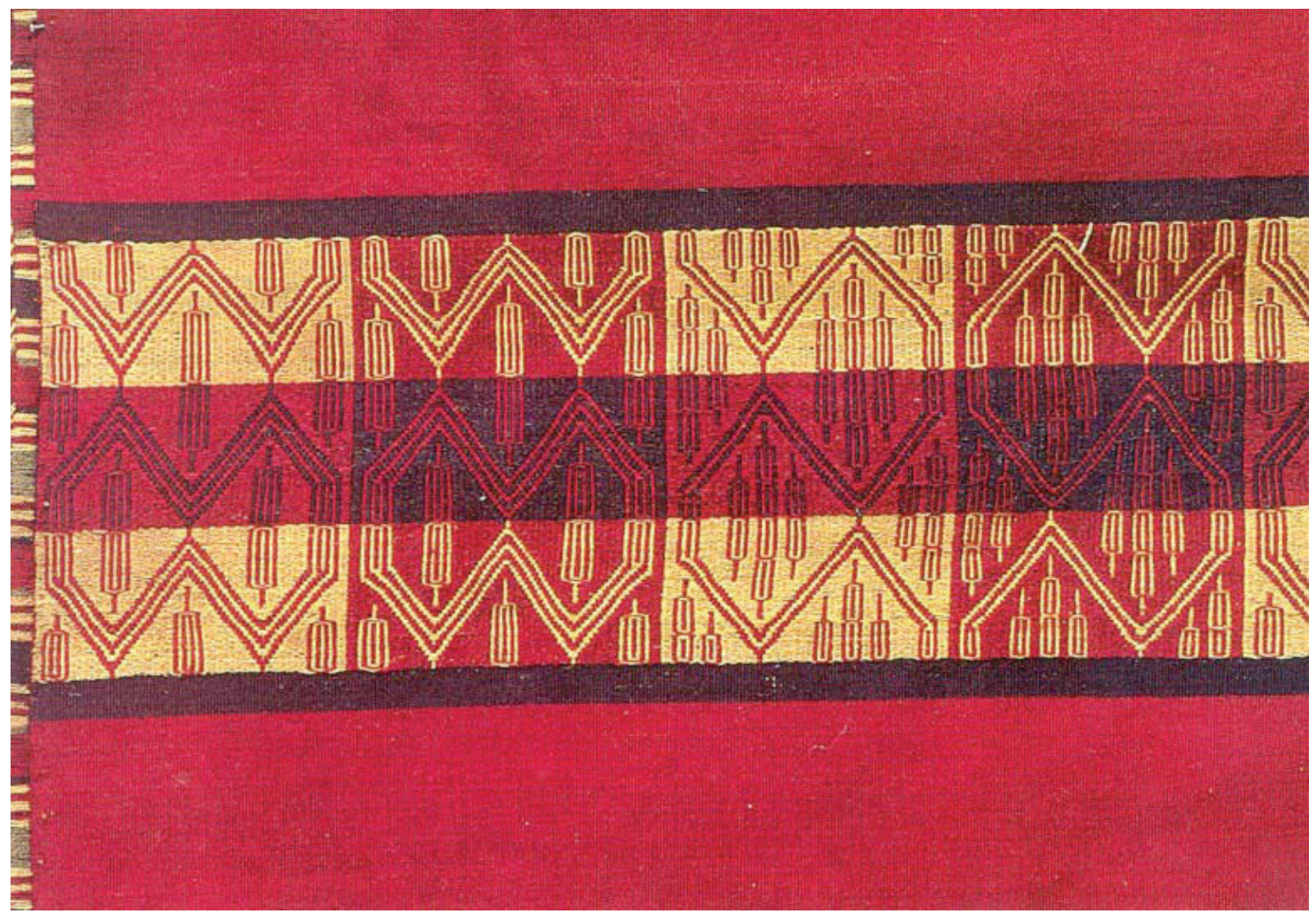

Figura 31. Detalle de otra lliklla. Formato mayor (The Textile Museum, en Phips et al. 2004: 22, también en la tapa de Rowe (1977)). Figure 31. Detail of another lliklla. Larger format (The Textile Museum, in Phips et al. 2004: 22, also on the cover of Rowe (1977)).

lleva igualmente el extraordinario pallay de serpientes dobladas en zigzag o zigzags continuos, con ojos intermedios, tan obsesiva en los santuarios de altura (Chávez 1999: 143).

Un ejemplo de estos textiles de formato mayor, conservado en muy buen estado, altamente atractivo, es la pieza textil especial resguardada en el Museo Nacional de la ciudad de Bogotá. Se trata de un manto atribuido a la esposa del último Inka, Atawallpa.

En 1825, Sucre, el Mariscal de Ayacucho, escribe una carta a Jerónimo Tenorio, entonces director del Museo Nacional de Bogotá, Colombia. En ella dice:

Me es muy agradable remitir a V.S. el manto o acsu de la reina mujer de Atahualpa que he podido conseguir como un monumento de antigüedad digno del Museo de la capital de Colombia, y mucho más digno después que las tropas de nuestra patria han vengado la sangre de los inocentes incas y libertado su antiguo imperio (AMNC, 12.9.1825. Reg. 1093). ${ }^{44}$
El manto o aqsu, que en realidad es un aqsu, nos es profundamente familiar a través de los textiles ya examinados de capacocha.

Tuvo que haberse tejido con mucha anterioridad, ya que su confección tan fina precisó de mucho tiempo. No creemos que ninguna de las esposas del Inka pudo haber sido su propietaria. Más bien, posiblemente se confeccionó para una ceremonia que no alcanzó a realizarse, conservándose por siglos como un objeto precioso. A estas prendas mayores conocidas se agregan las diez llikllas mantas y nueve aqsus, provenientes de Esmeralda (Hoces de la Guardia \& Rojas 2016).

Varios aqsus y llikllas en formato grande con este mismo diseño, ilustran el exhaustivo trabajo de A. Rowe; aunque las imágenes van sin colores, ella los describe en detalle (Rowe 1995-1996). Salvo contados casos en que estas prendas coinciden con las que hemos ido citando, la gran mayoría perteneciente a Museos o colecciones privadas, no tienen los datos de su con- 


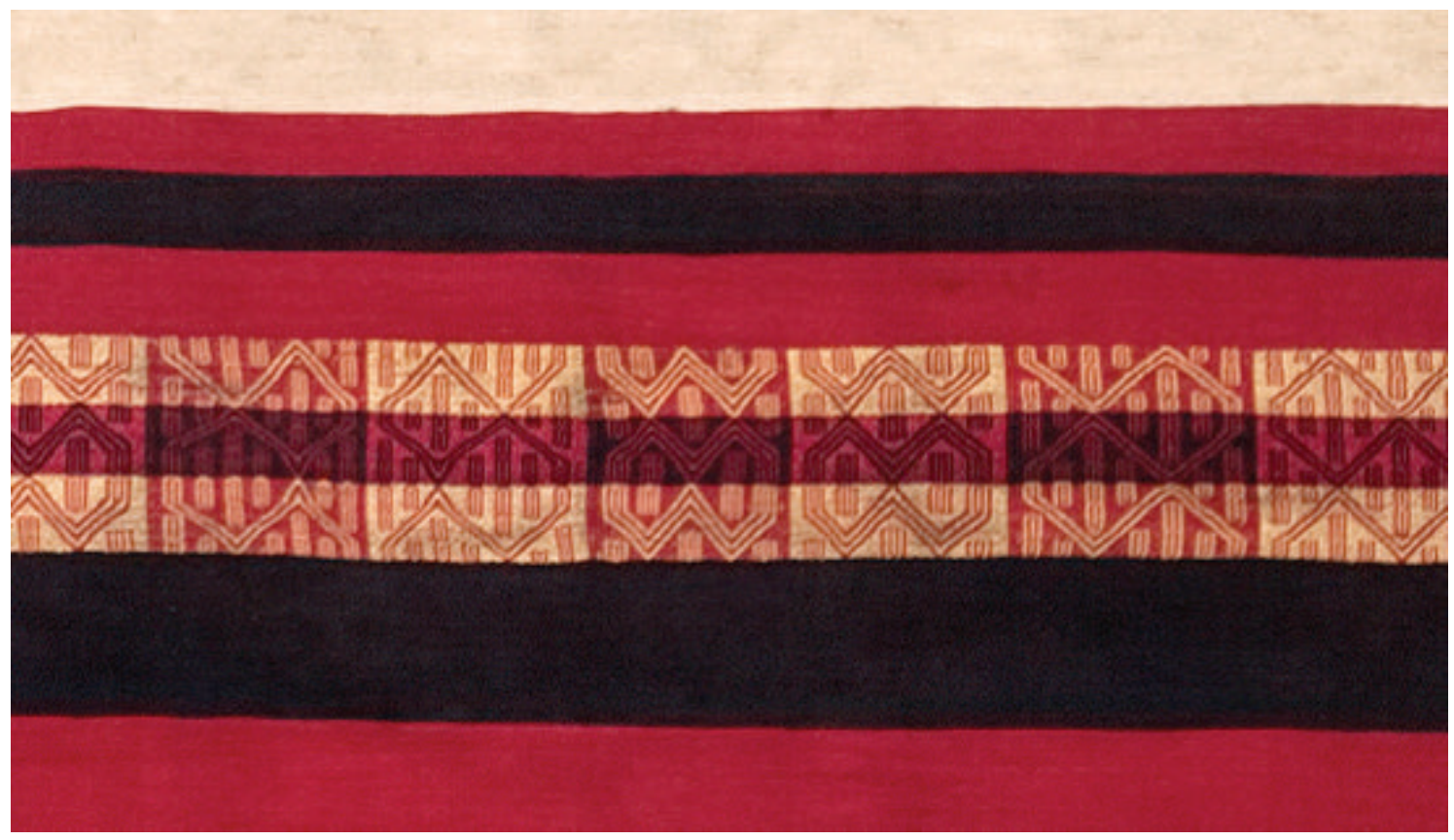

Figura 32. Detalle del aqsu atribuido a la esposa de Atawallpa. Nótese cuán claramente puede observarse aquí la formación de rombos y hexágonos, más el contacto de las serpientes entre ellas como con los bordes del pallay (Acosta et al. 2011). Figure 32. Detail of the aqsu attributed to Atawallpa's wife. A clear formation of rhombuses and hexagons can be observed here, along with the contact of the snakes with each other and with the pallay edges (Acosta et al. 2011).

texto arqueológico. Sin embargo, podemos reconocer los textiles que llevan el sello de las capacocha en las estructuras y dibujos.

Entre este conjunto de vestimentas de tamaño mayor, agrupadas por zigzags, a veces claramente ofidios, $y$ puntos o círculos, hay un ejemplo de una sin diseño: es decir, del tipo A, sin pallay, sin hilos teñidos, encontrada en Pica, oasis del norte de Chile (Rowe 1995-1996: fig. 17). No conocemos otro ejemplar de gran formato que lleve solamente tonos naturales. A pesar de que sugiere menor dominio de técnicas (ni pallay ni tintorería), su tejido fino de 150 tramas por centímetro cuadrado, lo contradice. La evocación de su posible pertenencia a pueblos, mundos o lugares más primitivos, va solo en la imagen, no en la confección del tejido.

La existencia de prendas en un formato mayor plantea, necesariamente, la relación entre pequeñas y grandes. ¿Es posible considerar a las más diminutas como miniaturas de las mayores?

Figura 33. El enorme formato de este aqsu. Figure 33. Aqsu in large format.

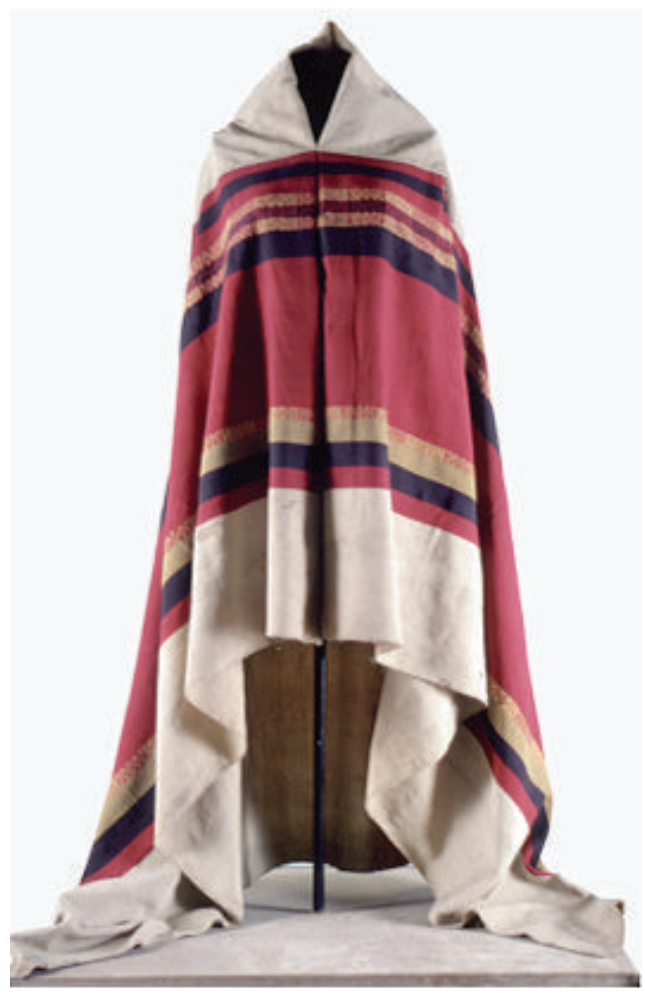




\section{¿MINIATURAS? ¿MODELO MENOR?}

Entre los pueblos de los Andes, son bien conocidos numerosos objetos muy pequeños, conservados y manipulados para la obtención de bienes, reproducción del ganado o suerte. Algunos son fabricados por sus futuros dueños, pero podrían encontrarse ya como piedra u otro material, con una forma que recuerda aquello que se desea poseer. Llevan diferentes nombres, como conopa, inqaychu o illa. Allen (2016: 193) los analiza en profundidad y describe los inqaychu como prototipos de piedra, en miniatura, de animales domésticos y plantas que representan la fertilidad y el bienestar de la tropa y los frutos. Los inqaychu son, según Allen, más o menos equivalentes, a illa o konopa.

Siendo igualmente pequeñas y fabricadas por un trabajo artesanal, las estatuillas de oro, plata y Spondylus enterradas en las capacochas, se diferencian de esas otras miniaturas más conocidas. No están destinadas a un uso familiar. Las ceremonias en las que fueron enterradas correspondían a importantes rituales del Estado Inka y no a actitudes votivas de un propietario particular de este tipo de objetos, quien lo conserva para su propia prosperidad.

Para Allen, los inqaychu son prototipos en miniatura (2016: 193). Es difícil establecer el "prototipo" al que pertenecerían las estatuitas, con relación a su reducción a partir de un ser que tendría un formato mayor. Tan estandarizadas, rígidas, llevando elementos específicos que no solamente les dan una identificación cultural, sino que, también, las unifican entre sí ¿de qué entidad superior formaría parte su esencia? No parecen ser un todo con las niñas o muchachas enterradas junto a ellas. Tanto la momia de la "Doncella" de Llullaillaco como de la "Juanita" de Ambato llevan cabellos cortos y sin trenzar, a diferencia de las pequeñas estatuillas, y no conforman un conjunto, ya que visten diferentes ropajes. Conklin (1996: 105) señala que los vestidos usados por "Juanita": "eran similares a su envoltura [un amplio textil tejido solamente en faz de urdimbre], eran café.."

Este mismo autor, que describe en detalle los vestuarios de las momias de Ambato, no indica que la lliklla que la acompaña llevando el diseño en serpientes estuviese cogida a su cuello con un tupu. Y Checura es ambiguo cuando habla de las vestimentas de las momias del enterratorio del cerro Esmeralda. Se refiere a ellas como "ajuares" que indudablemente estaban entre las ofrendas, pero sin indicar que alguna prenda hubiese sido encontrada sobre sus cuerpos. "La mayor y más importante pieza textil parece haber sido removida y debe atribuirsele a la momia adulta" (Checura 1977: 127, destacado mío).

Incluso, en algunas capacochas, la figurita no se corresponde necesariamente con el sexo del infante sacrificado. En el adoratorio del cerro El Plomo se trata de un niño, pero una estatuita femenina lo acompaña, lo que haría difícil suponer una identificación esencial entre ambos.

¿Qué sucede, en cambio, con sus pequeñas vestimentas? Esas prendas sí tienen otras relaciones con el mismo tema en formato más grande y existe una innegable unidad de lenguaje entre mayores y menores. Su relación mutua plantea, sin embargo -a pesar de esa semejanza- una diferencia fundamental: los diminutos aqsus, llikllas y chumpis visten a seres concretos, las estatuitas, que llevan ya una personalidad con características propias. Por lo que se conoce hasta aquí, los aqsus de gran formato con el pallay que es nuestro tema, no vestían a las muchachas enterradas, no estaban cubriendo sus cuerpos ni iban ceñidos a sus cinturas con un chumpi. Las llikllas -como la de la "Juanita"-, tal vez "incanizaban" a jóvenes venidas de otras regiones no cusqueñas, convocadas para ser inmoladas en estas ceremonias, pero sin negarles su anterior etnicidad la que era conservada en los aqsus. Las figurillas acompañantes no son el doble ni el mismo personaje que el que fue enterrado.

¿Por qué nos interesa esta diferencia? Por el hecho de que el diseño parece, a veces, trabajar a solas, con o sin un ser concreto al que pertenecería el ropaje en el que está inscrito. ¿A quienes representan trajes no destinados a un cuerpo? Pensamos que a sí mismos. Tendrían un kausaq y es el diseño el que les da su personalidad como seres con vida propia.

Hay una gran cantidad de referencias a ofrendas de textiles en los Andes en diferentes ceremonias descritas por los cronistas, que consistían en textiles aislados de algún portador que no necesariamente habían sido ya utilizados: en sí mismos eran ya obsequios de reciprocidad. Podría ser esta la condición de las prendas en formato mayor presentes en las capacocha. Algunos detalles confirman esta apreciación.

Se tienen las medidas publicadas de algunos aqsus y llikllas pertenecientes a museos o colecciones privadas. En varios, el tamaño es demasiado grande como para adecuarse a una talla femenina en los Andes. El aqsu 
conservado en el Museo Nacional de Bogotá es enorme, más de 2,60 m de largo (Acosta et al. 2011), lo que hace muy difícil que fuese destinado a una utilización como vestuario. Hubiese arrastrado por el suelo, por mucho que se lo doblase en dos, como era la costumbre de las mujeres de la nobleza inka: habría dado demasiadas vueltas a la cintura al ajustarse con una faja, que era y sigue siendo lo habitual para este traje de mujer. Y está impecable, a diferencia de los vestidos puestos directamente en el cuerpo de las momias. Lo mismo sucede con otros ejemplos de aqsus con este diseño. Por ejemplo, el que proviene de Pachacamac, mide 2,15 m de largo por 1,58 $\mathrm{m}$ de ancho (Phipps 2004: 22).

Más aún, para alcanzar estas dimensiones, a ambos aqsus se les ha añadido una pieza intermedia de modo que están formados por tres partes y no solo dos, que es lo corriente. En lo que conocemos hasta aquí, no se han encontrado aqsus tejidos en tres partes independientes y luego cosidas en las prendas en miniatura. Otros aqsus, aunque de tamaño más grande, según las especificaciones de Rowe, serían incluso demasiado pequeños para mujeres adultas (ella misma sugiere que difícilmente niñas vestirían estos trajes tan costosamente elaborados). Asombran estas diferencias de tamaños en prendas tan normadas como las vestimentas inkaicas. Posiblemente, no debieron estar destinadas a una portadora.

El diseño que no tiene límites físicos con la tela en que está inserto (no va costurado ni tejido aparte), sino tan solamente táctiles (más relieve) y visuales (tintes e íconos), ¿podría ser considerado en aquel entonces un ser discreto que entablaba diálogo con otros sujetos, en este caso no humanos, en las altas cumbres donde fue depositado?, ¿o solo modificaba como una pintura corporal o facial, a la personalidad de las estatuitas con su traje?

Trozos de tejido, al parecer sin una forma específica determinante, pero con diseño, han sido hallados en enterratorios. Por ejemplo, en el Mausoleo Imperial Wari hay un trozo de tapiz con dibujos, y según el arqueólogo que lo describe, "posiblemente se trate de un patrón significativo" [el dibujo en sí mismo] "pues, en la tumba se puede observar la presencia de fragmentos de otros tejidos" (Przadka-Giersz 2014: 108).

Son justamente los diseños, con su ausencia, los que permiten distinguir un tipo de vestimenta especial entre las figuritas femeninas: el que no lleva dibujos ni tonos teñidos, a pesar de que vista a estatuitas no solo de Spondylus, sino también de plata. ¿Cómo compren- der esta posible fuerza vital y espiritual de un angosto pallay que va dando identidad a personajes tangibles, pero también intangibles?

\section{La conservación milenaria de estas formas gráficas}

Conklin ha perseguido en un estudio esta imagen textil del zigzag con puntos intercalados o círculos a través de los siglos, denominándola "Diseño arriba y abajo en los textiles inka femeninos" (over-and-under pattern) (Conklin 1996: 126-128), cuando se repite horizontalmente.

Destaca que las guardas con dibujo se duplican iguales, sin simetría de espejo, como si se trasladaran. $\mathrm{Su}$ trabajo aporta ejemplos desde textiles Tiwanaku hasta la lliklla de la momia de la "Juanita", en Ambato. Para él, este zigzag con punto o círculos no tendría cientos de años, sino más de un milenio de antigüedad y conservaría una extraordinaria memoria textil andina y estaría ya presente en la cultura Pucara (Conklin 1996: 126-128).

Horta (1999: 86) agrega a estos datos de repetición de un diseño gráfico la continuidad de la serpiente bicéfala, de cuerpo zigzagueante, ya representada en una bolsa-faja ( $\left.\mathrm{n}^{\circ} 2161\right)$ del sitio de Maytas-Chiribaya (750-1300 DC Azapa-Chile). Curiosamente, los pequeños hexágonos que pudieron equivaler a círculos van al interior de su cuerpo; hexágonos que también reemplazan, algunas veces, a las formas más redondas de ojos intercaladas en los zigzags de algunos textiles de sacrificios de altura. Para ilustrarla más nítidamente, Horta utiliza una imagen de un diseño semejante en un unku del sur peruano, publicado por Rowe (fig. 34).

\section{¿DE QUÉ HABLAN? ¿¿QUÉ SOLICITAN LOS DISEÑOS?}

En esas complejas y trascendentes ceremonias capacocha, el diminuto diseño en las prendas de figuritas enterradas, tan recurrente, ha jugado necesariamente un papel propio. Hemos estado intentando una lectura de muchos de sus rasgos determinantes, dejando varios que se escapan a nuestras posibilidades de decodificación. Por ejemplo: las diferentes cantidades de ojos situados en los ángulos y que establecen nuevas combinaciones cuando se reúnen tres pallay, en una franja (como ha sido posible observar cuando se trata de tres diseños, 
el más oscuro al interior); la franja roja que incluye los dibujos y los destaca, ¿por qué a veces más ancha, a veces más angosta?; el diferente grosor del amaru. Pensamos que, a pesar de estos vacíos en la interpretación de este lenguaje plástico, la conjunción de negro, rojo, amarillo, más el zigzag y las serpientes bicéfalas, van formulando ya un texto.

¿Se refiere solamente, como hemos ido leyendo, a la existencia de enlaces necesarios de mundos o de situaciones opuestas o a las transformaciones de unos en otros?

\section{INTENTANDO ALGUNAS CONCLUSIONES}

¿El diseño expresa solo la existencia de una conjunción de mundos, de dos estados político-sociales, de las alternancias entre la luz del día y la penumbra de la noche? Recordemos, sin embargo, dos rasgos especiales de estas imágenes que hemos revisado: la calidad de reversibles atribuida a las serpientes -que en este caso son bicéfalas- y los trazos que las unen entre ellas. Según Allen, "pueden beber agua en dos direcciones", pueden trastocar un fenómeno. De ahí su peligro. De modo que las rectas que unen sus cuerpos entre sí, permiten verlas como si estuviesen amarradas, y el tejedor o la tejedora las va haciendo nacer directamente de los bordes de los rectángulos, sin solución de continuidad, dando la impresión que estos reptiles están pegados a ellos. Es imposible no leer a los amarus como voluntariamente detenidos en su potencialidad de anunciar y participar en grandes trastornos o cambios.

Y son, justamente, estos dos rasgos los que nos permiten intuir el efecto ritual que se solicita a través de los pallay: serpientes inmovilizadas. ¡Que el Estado Inka, con su pasado y su presente, con su centro y periferia, permanezca, no cambie! ¡Que no se vuelque en un nuevo pachakuti!

Los diseños estarían ejecutando un trabajo ceremonial hacia las potencias no humanas de las altas cumbres, de ruego, de clamor diríamos por su insistencia, para la estabilidad del cosmos. Que la situación actual -la extraordinaria expansión cusqueña hacia nuevas regiones- se sostenga y, tal vez, prosiga con sus éxitos. $Y$ así, sostener al Tawatinsuyu, atando a las serpientes, si grandes acontecimientos de transformación del mundo o sociales no eran deseados.

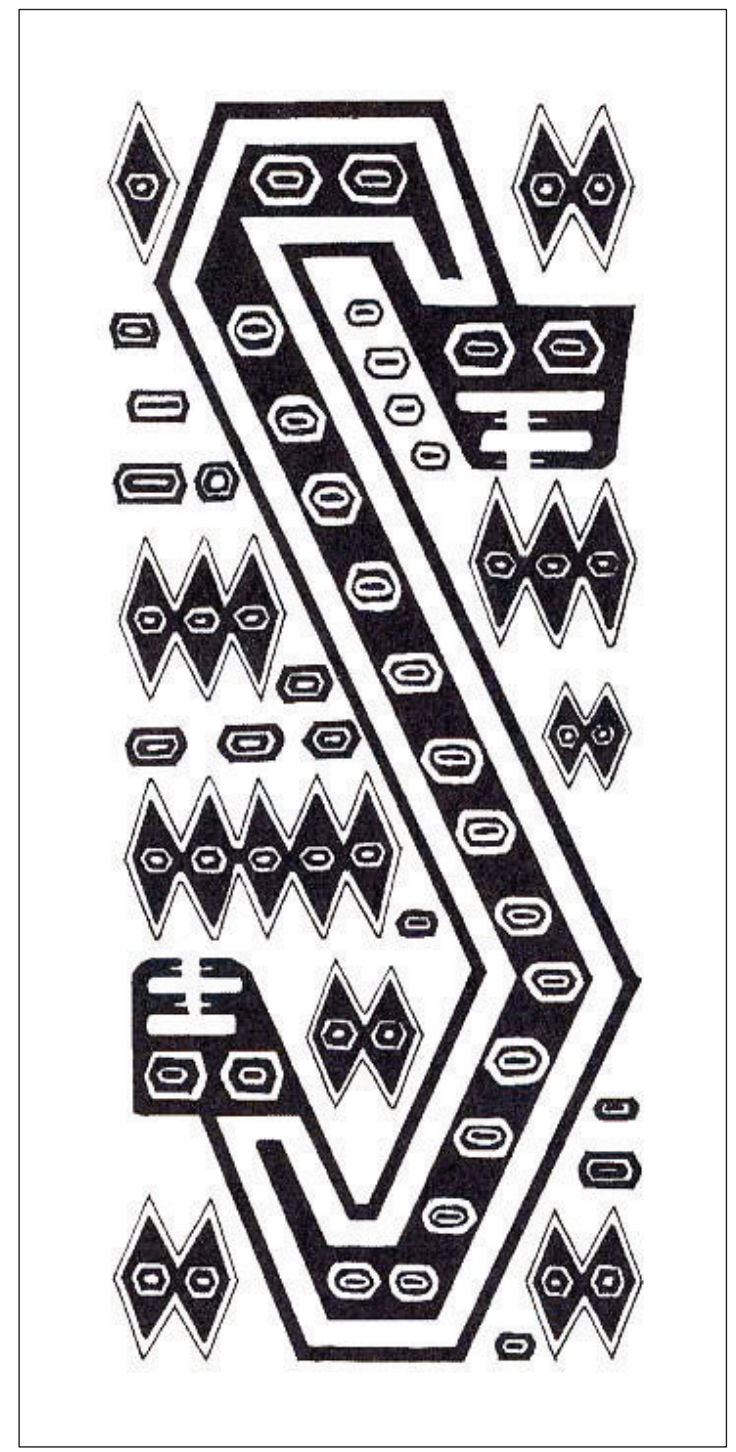

Figura 34. Serpiente bicéfala en zigzag con hexágonos interiores. Figure 34. Double-headed zigzag snake with inner hexagons.

En una primera instancia, los pallay se presentan como poderosos instrumentos de la memoria para recordar y enseñar los grandes hitos de la historia incaica, verdaderos documentos visuales de los mitos. Sin embargo, ¿quién podía observarlos y ser impresionado por ellos, salvo aquellos que los tejieron y los amautas, gentes sabias, que vigilaron su confección? Según relata el cronista Molina,

Tenían en tanta devoción este sacrificio llamado capacocha o cachaguaco que, si quando ivan caminando por los despoblados o otros lugares topaban alguna jente, no osaban 


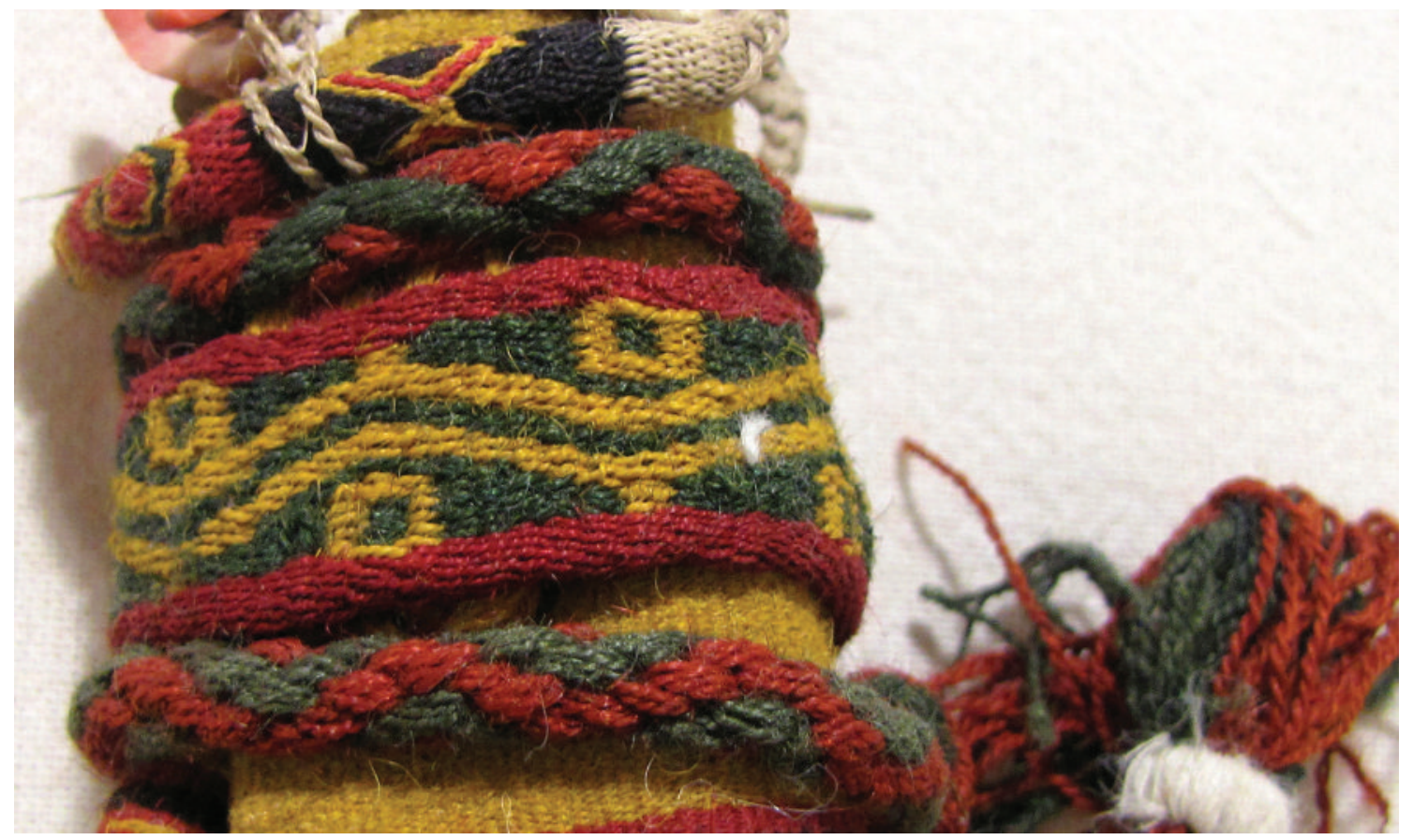

Figura 35. Chumpi. Se pueden observar los pequeños puntos amarillos que atan las serpientes a los bordes. Figure 35. Chumpi. Small yellow dots that tie the snakes to the edges can be observed.

los que así topavan los sacrificos alcar los ojos a mirallos, sino antes se postravan en tierra hasta que pasavan (Molina 2010 [1573]: 73).

Incluso los habitantes en los pueblos se encerraban en sus casas para no ver la caravana llevando las ofrendas. De modo que constituían un lenguaje secreto no accesible para otros que aquellos que los tejieron y a los amautas (sabios), que dirigieron su confección. Es posible que la acción ritual del pallay comenzara en el momento de ser tejido, es decir, cuando empezaba a existir.

Esta angosta semiótica plástico-visual reitera el papel que jugaban los propios infantes sacrificados como poderosos intermediarios ante las deidades, cuyo sacrificio y ceremonia era, según Benson (2001: 17-18, en Blom 2018: 573), "una manera de mantener el orden interno, tanto de las perspectivas sobrenaturales como estatales”. Así, ¿podría equivaler a las oraciones que clamaban rogando que cada día salga el sol (¡que no cambie el cosmos!), al enterrar ciertas ofrendas?: “ $\mathrm{OOh}$, Hacedor [Wiracocha], que diste [ser al sol] pues dijiste aya noche y día, amanecer y esclarezca, di a tu hijo el sol salga en paz! (Molina 2010 [1573]: 73).

Pero sin palabras y en silencio.
Agradecimientos Un agradecimiento muy especial al personal del Museo Arqueológico de Alta Montaña en Salta, MAAM, donde realizamos, junto con Jimena Montero, un trabajo de estudio de las vestimentas de figuritas de altura en 2011. A su entonces responsable de investigación, Dra. Silvia Soria, quien gestionó el permiso para extraer las estatuitas que estaban exhibidas de manera permanente en las vitrinas y lograr fotografiarlas una a una, en momentos en que el Museo estaba cerrado al público. Este trabajo no hubiese sido posible sin el gran apoyo de Pedro O. Santillán, encargado del laboratorio y custodia del material arqueológico, muchas gracias y recuerdos para él. Nuestro reconocimiento y admiración para Lizardo Maggipinto que, no solamente realizó la tarea fotográfica con excelencia, sino que, igualmente, contagió a todo el equipo con su pasión por el trabajo.

A mi amiga y colega Helena Horta por su gentileza al traspasarme varias láminas de estos pequeños vestuarios, pertenecientes a otros museos, y por nuestras intensas conversaciones en torno a este tema, siempre estimulantes. A Soledad Hoces de la Guardia y Ana María Rojas, por el gentil intercambio de materiales y, especialmente, por nuestra investigación conjunta para decidir si prendas mayores, que comparten el diseño de las pequeñas, se habían o no encontrado directamente puestas en los cuerpos de las momias. Muchas gracias a estas tres colegas y todo mi cariño para ellas.

Un gran agradecimiento también para Jimena Montero por su constante apoyo en este trabajo que llegó a pertenecerle por la dedicación que puso en él. Y a mis dos hijos, Rosalía Martínez 
Cereceda y José Luis Martínez Cereceda, quienes con paciencia leyeron el primer manuscrito. Sus observaciones fueron de gran importancia para mí.

Quisiera recordar aquí, las horas de intensa observación de las pequeñas vestimentas, junto a Pedro, Lizardo, Jimena y el personal del Museo que nos acompañaba con gran interés: luego de su hallazgo, salvo para algunas fotografías, las figuritas no habían sido removidas de las vitrinas, de modo que, al alzar las ropas caía polvo, piedritas, paja, que Pedro almacenaba cuidadosamente, emocionándonos.

Ya que todo ese aditamento estuvo ahí por más de quinientos años. Sentíamos el contacto con las personas que las vistieron tantos siglos atrás y con las que, llevándolas en interminables caravanas a pie, las depositaron con tanto respeto en las cumbres del Llullaillaco.

Una expectativa especial surgió cuando obtuvimos el permiso de desatar los cordones que sujetaban a las llakolla en los cuerpos masculinos. Algunas de estas mantitas masculinas estaban enrolladas en los cuerpos de las estatuillas, de tal modo que impedían la visión de las prendas interiores que componían la vestimenta. Se iba logrando deshacer los nudos con infinita paciencia y delicadeza, para volverlos a anudar exactamente como eran. Surgieron así unku y ch'uspa que nunca habían sido observados ni por el personal del museo ni por otros investigadores. De inmediato llamaron poderosamente la atención los diseños ya conocidos en unku de tamaño normal: en "damero" y en "llave Inca" -como designó a este tocapu John Rowe- y, otros más sencillos, con listas de colores. Por esos momentos únicos, nuevamente muchas gracias al Museo de Alta Montaña en Salta.

\section{NOTAS}

${ }^{1}$ La conjunción de sacrificios de infantes con la presencia de estatuillas humanas en miniatura con sus vestimentas, parece distinguir las capacochas de otras ceremonias de santuarios de altura. Otros investigadores hacen clasificaciones más amplias de estas ceremonias, como Gentile 2010, pero estos otros posibles rituales caen fuera de nuestro trabajo.

${ }^{2}$ Después de los clásicos trabajos de Duviols (1976) y Beorchia Nigris (1987), diferentes estudios han constituido el marco estratégico del presente texto: Chávez (1999), Narváez et al. (1995), Gentile (1999), Benson (2001), Vitry (2008), Mignone (2009), Reinhard y Ceruti (2010), Ceruti (2003), entre otros.

${ }^{3}$ El término Pallay designa tanto una de las técnicas andinas (urdimbres complementarias) que permite tejer dibujos, como el diseño resultante de ella.

4 "La mayor parte de estas figuras en miniatura se encuentran casi formalizadas o siguen una tipología de semiindustrialización, donde el orfebre debía respetar ciertas pautas fijas: dimensiones generales, cabellera dividida en dos campos con raya al medio para las mujeres y terminando en dos trenzas..." (Abal de Russo 2010: 241).
${ }^{5}$ Letchman (2007) destaca técnicas inkas que, trabajando amalgamas, permitían dejar estos metales más valiosos en la superficie, que es el caso de estas estatuillas. Las técnicas específicas de elaboración de las miniaturas de alta montaña han sido desarrolladas por Ceruti (2001), Abal de Russo (2010), Mignone (2009), entre otros.

${ }^{6}$ Este museo conserva las excavaciones de J. Reinhart y C. Ceruti, de una capacocha en el volcán Llullaillaco, a 6739 msnm, la cumbre más alta conocida donde se efectuaron estas ceremonias. En esta capacocha se ha encontrado el mayor número de estatuillas antropomorfas vestidas: 12 femeninas y 11 masculinas.

${ }^{7}$ Palma (1991) da un extraordinario detalle de este peinado analizando una figurita femenina procedente del volcán Copiapó: no serían trenzas sino mechones muy torcidos hacia el centro; en el lado derecho van torcidas en Z, en cambio, en el lado izquierdo de la cabeza, en $\mathrm{S}$-destaquemos su sentido opuesto-, torsiones casi siempre utilizadas en los hilos de telares andinos. Añade un dato extraordinario: "No se puede evitar recordar que el par de cordones laterales delgados de la faja" [en esta misma figurita] "presentan un detalle análogo". Es decir, los cabellos van torcidos al igual que los cordones de la faja, lo que destaca la importancia ritual de esa torsión, que podía ser aplicada igualmente al peinado (Palma 1991: 58). Las cabelleras de otras figuritas femeninas no han sido analizadas tan finamente, de modo que no es posible extender esta definición de "torsión" a todas las "trenzas" que mencionan los arqueólogos.

${ }^{8}$ Las referencias más directas de estos vestuarios corresponden al trabajo en el MAAM. Revisamos las 12 estatuillas femeninas excavadas del volcán Llullaillaco. A este corpus se sumó el análisis de figuritas observadas en la exposición "Inka" del Museo Chileno de Arte Precolombino: una proveniente de Las Tórtolas (MALs), una del volcán Copiapó (Museo Regional de Atacama), como láminas y fotografías publicadas de otros museos: sea de figuritas vestidas o de sus ropas ya sin el cuerpo al que pertenecieron. Se suman así a las primeras 14: tres de Ambato (Museo de Santuarios Andinos de la Universidad Católica Santa María, Arequipa), una de Túcume (Museo de sitio de Túcume, Lambayeque), una del volcán Pili (Museo de San Pedro de Atacama), una del cerro El Plomo (Museo Nacional de Historia Natural), dos (sin procedencia, Museo Nacional de Arqueología, Antropología e Historia del Perú), una del cerro Gallán (Museo Etnográfico B. Ambrosseti, UBA), dos de Quehuar (Ceruti 2001), una (sin procedencia Werner Forman Archive, Londres), una del cerro Mercedario, San Juan, Argentina, y dos del Tokyo National Museum of Science and Nature. Más muchas prendas aisladas conservadas en diferentes museos sin la estatuilla que vistieron o que nunca tuvieron. A este conjunto agregamos gran cantidad de vestuarios en miniatura publicados por A. Rowe (1995-1996), sin colores, pero muy bien descritos, pertenecientes a diferentes sitios. La mayoría de estas prendas no está acompañada de información sobre 
su procedencia. En este excelente trabajo, no encontramos las figuritas que estuvieron vestidas con esas ropas.

${ }^{9}$ Aunque conocemos, como excepciones, uno de cobre y uno de bronce.

${ }^{10}$ Trabajos serios y muy interesantes, que iremos citando, se han referido ya a estos pequeños vestuarios: Rowe (1977, 1995-1996), Palma (1991), Dranzart (1995), Martínez (2007), Abal de Russo (2010), Hoces de la Guardia y Rojas $(2013,2016)$. A pesar de los excelentes datos que nos proporcionan, ninguno se ha centrado aún en una lectura del diseño como un todo único, intentando incluir la gran mayoría de sus rasgos.

${ }^{11}$ En danzas étnicas aún vigentes en los Andes, a veces los hombres llevan impresionantes conjuntos de plumas en sus cabezas, pero no los hemos observado en trajes de danza femeninos con este desarrollo.

${ }^{12}$ El tamaño mayor de las prendas con respecto a las figuritas -en sí muy pequeño y difícil de tejer-, podría explicarse especialmente para logar los pallay en las que llevan diseños, como también por el hecho de que las estatuitas visten trajes ceremoniales y no de uso cotidiano.

${ }^{13}$ Esta diferenciación en el cromatismo de los vestuarios de estatuillas de altura no puede dejar de recordarnos que en el ayllu aymara de Isluga -altiplano chileno, frontera con Bolivia, donde realizamos un largo trabajo de campo- conformaba una etnocategoría: el término kura se refería únicamente al vellón de camélidos sin teñir, en tanto que $p^{\prime}$ ana designaba al vellón teñido, diferenciando también su uso en los textiles (Cereceda 2017 [1978]).

${ }^{14}$ Rowe cita una lliklla en miniatura con bandas y pampa en tonos café natural de alpaca, aunque lleva diseño, pero el pallay no va en rojo y amarillo como en todos los otros ejemplos que conocemos de estos dibujos en textiles de capacocha (Rowe: 1995-1996: fig. 50). Puede que no corresponda a este set que estamos intentando analizar: textiles de capacocha.

${ }^{15} \mathrm{Si}$ oro, plata y Spondylus constituyen posibles jerarquías en otros contextos, aquí parecen estar nivelados por las vestimentas.

${ }^{16}$ A partir de Gell (2016) y especialmente de los trabajos sobre relaciones entre humanos y no humanos ya planteadas para la Amazonía (Viveiros de Castro 2013 y otros), se han ido desarrollando nuevas perspectivas de lo que podría ser un "animismo andino", en objetos materiales que serían considerados con algún tipo de espiritualidad, con los que es posible dialogar, como Bray (2009) y Allen (2016, 2015), entre muchos otros investigadores. Aunque aceptando las justas críticas y observaciones en torno al carácter de "alteridad andina" que se les ha dado a estas relaciones entre humanos y objetos vividos como sujetos, por Salomón (2018: capítulo sexto), estos planteamientos nos permiten dar una salida teórica a las fuertes experiencias que han vivido etnógrafos -y la mía propia- cuando objetos materiales son tratados como seres vivos, en nuestras observaciones partici- pativas. Ver también Costa y Fausto (2009: 99), en torno a la necesidad de tratar con mayor complejidad estas relaciones ontológicas.

${ }^{17} \mathrm{Sin}$ acordar fechas precisas en las que se realizaron estas capacocha, muchos investigadores coinciden en considerarlas del Período Inka Tardío, pero en espacios de tiempo bastante amplios. Para Ceruti (2010: 17), sus límites "podrían establecerse en fechas de momentos significativos, como el del año 1438 DC, usualmente atribuida al inicio del gobierno de Pachakuti Inka Yupanqui y 1532 DC, fecha que señala el inicio del colapso del sistema de gobierno inkaico con la entrada de los conquistadores españoles". Gentile (2010: 820824) coincide en estas épocas tardías y asigna a la capacocha de Aconcagua la mayor cercanía, en el tiempo, a la presencia hispánica. Las ceremonias de El Plomo y Llullaillaco serían próximas a la de Aconcagua. Tratando de las pequeñas estatuitas metálicas, Gentile (2017: 44) fecha tentativamente la manufactura de los cuerpitos de oro y plata, después de la conquista inka del Collao y Chimú y sus orfebres, por Topa Inka Yupanqui.

18 "Si estas estatuillas hubiesen sido confeccionadas por artesanos locales en las regiones donde se hallaron, cada conjunto poseería características distintivas que las diferenciarían del resto, careciendo, además, en algunos lugares, de materias primas tan "exóticas" como las valvas marinas, procedentes exclusivamente del Ecuador, a miles de kilómetros de distancia de cualquiera de los adoratorios donde se localizaron estos objetos. Al haber sido hechas por artesanos especializados del Inkario, poseen una serie de elementos estandarizados que, seguramente, tenían la finalidad de transmitir un mensaje, ya sea a los humanos, a las divinidades o a ambos" (Vitry 2008: 12). En cambio, las figuritas de pequeños camélidos, que acompañan, también, muchos enterratorios de altura, según Mignone (2009), destacan notorias diferencias regionales.

${ }^{19}$ Estos diseños, naturalmente, son ya coloniales, pero se los considera como conservando aún una tradición preconquista (Guamán Poma de Ayala 1980 [1615], Fray Martín de Murúa, manuscritos Galvin 2004 [1590] y Getty 2008 [1611]).

${ }^{20}$ Tocapu: una organización gráfica de formas cuadradas con una figura generalmente abstracta, aunque a veces reconocible, inscrita en su interior. Siempre polícroma. Presentes en textiles y qerus de la época inka.

${ }^{21}$ Hoces de la Guardia y Rojas (2016: s/n), en su bien documentado trabajo sobre estos vestuarios, los designan como "vestimenta de mujeres en la nobleza inca". No coincidimos, sin embargo, en la consideración de esta vestimenta (con su diseño y cromatismo) como habiendo sido utilizado, en vida, por élites del Cusco. Anne Rowe ya mencionaba la ausencia de estos trajes en los dibujos de Guamán Poma (1996: 20).

${ }^{22}$ Ceruti (2003: 266-272) entrega otros rasgos que impiden considerar a estas víctimas como cusqueñas.

${ }^{23}$ Exposición “El Gran Inca Eterno” (1999: 71). 
${ }^{24}$ Casa de reclusión de doncellas que trabajaban, tejían y rezaban para las distintas deidades.

${ }^{25}$ Tendríamos así una cierta confirmación de que los nombres dados a los diferentes tipos de aqlla correspondían, igualmente, a los colores de su vestuario.

${ }^{26}$ Agradecemos a Sergio Barraza por proporcionarnos estas ilustraciones que permiten comprobar que las aqllas utilizaban -al menos en momentos rituales, como los que están incorporadas en las pinturas cerámicas- tonos de vestidos que coinciden con sus nombres. Si las estatuillas hubiesen vestido como mujeres escogidas tendríamos que agregar a las tres representadas en las ilustraciones de Barraza, a las con pampa blancas y pampas amarillas que tenemos en el corpus estudiado: conformarían un conjunto de cinco aqllas no citado por ningún cronista.

${ }^{27}$ Estas estructuras se confunden en ciertos casos con los ayllus del Cuzco: una masa enorme de mujeres no podría haber llevado estos trajes tan elaborados (Hernández 2008: 29-45).

${ }^{28}$ Los aqsus de estas pequeñas figuras no llevan festones coloridos, solamente las llikllas.

${ }^{29}$ Cumbi, la calidad de mayor excelencia en los textiles inkas.

${ }^{30}$ Recordemos que esta figura ha sido ya reconocida como serpiente en diferentes estudios (Herrera 1966: 59, Rowe 1977: 71, figs. 81 y 82, Horta 1999: 86, 89, entre otros).

${ }^{31}$ Igualmente, los círculos han sido identificados como “ojos". Rowe (1977: 7), describe este diseño como "variaciones de un zigzag con ojos".

${ }^{32}$ En los estrechos festones que rodean el borde de algunas llikllas pueden ir tonos desaturados, es decir, no intensos, pero en muy poca cantidad.

${ }^{33}$ No estamos abordando en este trabajo los trajes de las estatuillas que corresponden a varones. Solo los mencionamos cuando reiteran algún rasgo de los diseños femeninos.

${ }^{34}$ Dato obtenido de nuestro trabajo con numerosas tejedoras entre los años 1973 y 1976. Otras investigadoras de los textiles de Isluga, posteriores a este período, se refieren ahora a este diseño con otros nombres. Con los grandes cambios en el ayllu, este semantismo anterior, muy compartido antes, parece haberse olvidado.

${ }^{35}$ Un pañuelo blanco grande puesto en la cabeza, con nudos en sus cuatro esquinas, sugería la idea de cuatro cachos, y vestidos en allqa (contraste) con mantas rosadas y verdes o naranjas y moradas, encontradas en ángulos, definían cuatro partes en oposición cromática sobre sus cuerpos. Directamente llamados diablos. El texto que cito corresponde a mis apuntes de campo (un relato más detallado de esta ceremonia en Martínez 1974: 2-11).

${ }^{36}$ El zigzag aparece en estos tubos o mangos de la paqcha también como un rombo en algunos otros vasos, cuando se unen las esquinas dejadas por las rectas quebradas. En los diseños de los pequeños aqsus femeninos, a veces se insinúan estos rombos, pero nunca de manera perfecta.
${ }^{37}$ Antonio de Vega da una descripción del ídolo Punchao o "Sol del día" que se construyó según esta imagen vista en la fuente de Susurpuquio: "en los encuentros de los brazos unas culebras enroscadas" y "una manera de culebra que le tomaba de lo alto de las espaldas abajo" (Zuidema 1974: 205).

${ }^{38}$ Urdimbres complementarias.

${ }^{39}$ No es problema tejer curvas con hebras muy finas. Puede observarse en estos propios ejemplos, en las cabezas o en ojos que, a veces, son casi un círculo.

${ }^{40}$ Layra, expresión local de nayra.

${ }^{41}$ Rowe publica otra (1995-1996: 55-74).

${ }^{42}$ Gentile "Tocapu: unidad de sentido" <https://pendientedemigracion.ucm.es/info/especulo/numero45/tocapu. html> [consultado 14-04-2020].

${ }^{43}$ Estas prendas mayores han sido catalogadas y analizadas posteriormente por Hoces de la Guardia y Ana María Rojas (2016).

${ }^{44}$ Agradezco a P. Quisbert el haberme dado a conocer esta correspondencia.

\section{REFERENCIAS}

Abal de Russo, C. 2010. Arte textil incaico en ofrendatorios de la alta cordillera andina. Aconcagua, Llullaillaco, Chuscha. Buenos Aires: Fundación CEPPA.

Abercrombie, T. 2006. Caminos de la memoria y el poder: etnografía e historia en una comunidad andina. La Paz: IFEA-Instituto de Estudios Bolivianos.

Acosta, O. \& Plaza, M. C. 2011. El manto o acso de la reina mujer de Atahualpa. ¿Una prenda de la última reina del Perú? Cuadernos de Curaduría. Bogotá: Museo Nacional de Colombia. <http://www.museonacional.gov.co/imagenes/publicaciones/El_manto_o_acso_de_la_reina.pdf> [consultado: 25-12-2019].

Allen, C. 2002. The Incas had gone inside: patterns and persistence in andean iconography. Antrhopology and Aesthetic 42: 180-203. Cambridge: Peabody Museum.

Allen, C. 2015. The whole world is watching. New perspectives on andean animism. En The archaeology of wak'as: explorations of the sacred in the Pre-Columbian Andes, T. Bray, Ed. 23-46. Colorado: University Press of Colorado.

Allen, C. 2016. The livings ones. Miniatures and animation in the Andes. Journal of Anthropological Reaserch 72 (4). $<$ https://www.ncl.ac.uk/media/wwwnclacuk/clacs/Catherine\%20Allen.pdf > [consultado: 25-12-2019].

ARTZI, B. 2016. ...y son indios por conquistar: las alegorías femeninas de los cuatro suyus en el testimonio etnohistórico y arqueológico. Revista Andina 53: 301-340.

BArrazA, S. 2012. Sub estilo de inca imperial. Tesis para optar al grado de Magíster en Arqueología. Pontificia Universidad Católica de Lima, Lima. 
Benson, E. P. 2001. Why sacrifice? En Ritual sacrifice in ancient Peru, E. P. Benson \& A. G. Cook, Eds., pp. 1-33. Austin: University of Texas Press.

Beorchia, A. 1987. Arqueología de alta montaña. San Juan: CIDAM.

Bertonio, L. 1984 [1612]. Vocabulario de la lengua aymara. La PaZ: CERES-IFEA-MUSEF.

BLom, D. 2018. Child Sacrifice in the ancient Andes: power and sociopolitical dynamics in antiquity. En Manual de Oxford de la arqueología de la infancia, S. Crawford, D. Hadley \& G. Shepherd, Eds., pp. 573-589. Oxford: Oxford University Press.

BraY, T. 2009. An archaeological perspective on the Andean concept of camaquen: thinking through Late Pre-Columbian ofrendas and huacas. Cambridge Archaeological Journal 19 (3): 357-366.

Bray, T., Minc, L., Ceruti, C., Chávez, A., Perea, R. \& REINHARD, J. 2005. A compositional analysis of pottery vessels associated with the inca ritual of capacocha. Journal of Anthropological Archaeology 24 (1): 82-100.

CerecedA, V. 2017 [1978]. Semiología de los textiles andinos: las talegas de Isluga. En De los ojos hacia el alma, V. Cereceda, Ed., pp. 11-42. La Paz: Plural.

Cereceda, V. 2017 [1980]. A partir de los colores de un pájaro... En De los ojos hacia el alma, V. Cereceda, Ed., pp. 43-110. La Paz: Plural.

Cereceda, V. 2017 [1987]. Aproximaciones a una estética andina: de la belleza al tinku. En De los ojos hacia el alma, V. Cereceda, Ed., pp. 111-185. La Paz: Plural.

Cereceda, V. 2017. De los ojos hacia el alma. La Paz: Plural.

Ceruti, M. C. 2001. Llullaillaco. Sacrificio y ofrendas en un santuario inca de alta montaña. Tesis para optar al grado de Doctora en Arqueología, Universidad Nacional de Cuyo, Cuyo.

Ceruti, M. C. 2003. Elegidos de los Dioses: identidad y estatus en las víctimas sacrificiales del volcán Llullaillaco. Boletín de Arqueología PUCP 7: 263-275.

Chávez, J. A. 1999. La niña inca que retornó de la montaña. En Exposición del Gran Inca Eterno. La tristeza de la niña "Juanita", F. Rosas, J. A. Chávez, M. Sakai \& K. Inikuci, Eds., pp. 82-87. Tokio: National Museum of Science and Nature.

Checura, J. 1977. Funebria incaica en el cerro Esmeralda. Iquique. I Región. Estudios Atacameños 5: 127-144.

Conklin, W. 1983. Pucara and Tiahuanaco textiles: time and style in the highland weaving tradition. Naupa Pacha 21: 1-44.

Conklin, W. 1996. The Ampato textiles offerings. En Sacred and ceremonial textiles. Proceedings of the Fifht Biennal Symposium of the Society of America, pp. 104-110. Chicago: Textile Society of America.

Costa L. \& Fausto, C. 2009. El regreso de los animistas: estudios recientes de ontologías amazónicas. Religion and Society: Advances in Research 1: 89-109.

De Rojas, D. 2008. Los tocapu. Graficación de la emblemática inka. La Paz: CIMA.
Dranzart, P. 1995. Elemental meanings: symbolic expression in inka miniature figurines. Londres: Institute of Latin American Studies.

Duviols, P. 1976. La capacocha. Ritos y rituales andinos. Allpanchis 9: 11-57.

Garcilaso de la Vega. 1991 [1590]. Comentarios reales de los Incas. México DF: Fondo de Cultura Económica.

Gell, A. 2016. Arte y Agencia. Una teoría Antropológica. Buenos Aires: $\mathrm{Sb}$.

Gentile, M. 1999. Huacca Muchay, religión indígena: religión, creencias, juegos área andina argentina prehispánica, colonial, actual. Buenos Aires: Instituto Nacional Superior del Profesorado de Folklore.

Gentile, M. 2010. Tocapu: unidad de sentido en el lenguaje gráfico andino. Revista Digital Cuatrimestral 45: 1-31. $<$ http://webs.ucm.es/info/especulo/numero45/tocapu. html> [consultado: 25-12-2019].

Gentile, M. 2017. Iconología de un diseño incaico en textiles de Llullaillaco. Revista Cruz del Sur 26: 127-179.

Gentile, M. 2017a. La fundación incaica del oráculo capacocha en el Collasuyu: secuelas de una nota a pie de página. Revista Cruz del Sur 22: 11-83.

Gentile, M. 2017b. Iconología de un diseño incaico en textiles de Llullaillaco. Revista Cruz del Sur 26: 127-179.

Guamán Poma, F. 1980 [1615]. El primer nueva crónica y buen gobierno. México DF: Siglo XXI.

Hernández, F. 2008. Las panacas y el poder en el Tahuantinsuyu. Bulletin de l'IfEA 37: 29-455.

Herrera, J. 1996. Símbolos de identidad y estatus en las bolsas faja de la costa de Arica. Revista de Historia Indígena 1: 55-64.

Hoces de la Guardia, S. \& Rojas, A. M. 2013. Carácter representacional de ofrendas textiles incaicas. Envíos para el más allá. Diseña 6: 138-145.

Hoces de la Guardia, S. \& Rojas, A. M. 2016a. Vestimentas de mujeres en la nobleza inca. Ajuar textil en el enterratorio del cerro Esmeralda y sus relaciones con los textiles de estatuillas en miniatura. Nuevo Mundo Mundos Nuevos. Colloques. <https://journals.openedition.org/nuevomundo/69833> [consultado: 25-12-2019].

Hoces de la Guardia, S. \& Rojas, A. M. 2016b. Carácter representacional de ofrendas textiles incaicas. Envíos para el más allá. Diseña 6: 1-4. <https://diseno.uc.cl/publicacion/ caracter-representacional-de-ofrendas-textiles-incaicasenvios-para-el-mas-alla-2/> [consultado: 25-12-2019].

Horta, H. 1999. Estudio iconográfico de textiles arqueológicos del valle de Azapa, Arica. Chungara 29 (1): 81-108.

Horta, H. 2018. El adorno de barbilla de los señores altiplánicos como símbolo de continuidad histórica y emblema étnico en los Andes del sur. En Interpretando huellas. Arqueología, etnohistoria y etnografía de los Andes y sus tierras bajas. M. Muñoz, Ed., pp. 605-618. Cochabamba: Kipus.

Letchman, H. 2007. The Inka and Andean metalurgical tradition. En Variations in the expression of Inka Power, R. Burger, C. 
Morris \& R. Matos, Eds., pp. 313-355. Dumbarton Oaks: Trustees for Harvard University.

Lothrop, S. 1956. Peruvian pacchas and keros. American Antiquity 21 (3): 233-243.

Manheimm, B. 1991. La lengua de los incas después de la invasión europea. Texas: University of Texas Press.

MartíneZ, G. 1977. Humor y sacralidad en el mundo autóctono andino. Iquique: Universidad de Chile, Sede Iquique.

Martínez, I. 2007. Acsu, lliclla y panacas: la vestimenta de las ofrendas antropomorfas incas como símbolo de poder. En Actas IV Jornadas Internacionales sobre textiles precolombinos, V. Solanilla, Ed., pp. 535-549. Barcelona: Universidad Autónoma de Barcelona.

Mignone, P. 2009. Miniaturas zoomorfas del volcán Llullaillaco y contraste entre el régimen estatal y vida comunitaria en la capacocha. Boletín del Museo Chileno de Arte Precolombino 14 (1): 55-68.

Molina, C. 2010 [1575]. Relación de las fábulas y ritos de los Incas. Madrid: Iberoamericana-Vervuert.

Murúa. M. 2004 [1590]. Historia General del Perú. Origen y descendencia de los Incas. Manuscrito Galvin. Madrid: Testimonio.

Murúa. M. 2008 [1612-1614]. Historia General del Perú. Origen y descendencia de los Incas. Manuscrito Galvin. Los Ángeles: The Getty Research Institute.

Narváez, A., Heyerdahl, T. \& Sabderweiss, T. 1995. Piramids of Tucume: the quest for Peru's forgotten city. Londres: A. Thames \& Hudson.

PALMA, J. 1991. Documentación de dos miniaturas antropomorfas encontradas en el volcán Copiapó. Revista Contribución Arqueológica 3: 57-88.

PAul, A. 1982. The symbolism of paracas turban: a consideration of style, serpents, and hair. Naupa Pacha 20: 41-60.

Paulinyi, M. 2018. Las bolsas chuspas de un cementerio prehispánico de Arica (Chile): estilo textil y multietnicidad. Madrid: Editorial Academia Española.

Phipps, E. 2004. Garments and identity in the Colonial Andes. The colonial Andes. Tapestry and silverwork. 1530-1830, E. Phipps, Ed., pp. 17-39. Nueva York: The Metropolitan Museum of Art.

Phipps, E., Hecht, J. \& Esteras, C. 2004. Inca antecedents. The colonial Andes. Tapestries and silverwork. 1530-1830, E. Phipps, Ed., pp. 131. Nueva York: The Metropolitan Museum of Art.

PrzadKA-Giersz, P. 2014. El castillo de Huarmey. El mausoleo imperial Huari. M. Giersz \& C. Prada, Eds., 101-127. Lima: Museo de Arte de Lima.

Ramos Gavilán, A. 1976 [1621]. Historia de Nuestra Señora de Copacabana. La Paz: Academia Boliviana de Historia.

REIHARD, J. \& CERUTI, C. 2010. Inca rituals and sacred mountains. A study of the world's highest archaeological sites. California: Cotsen Institute of Archaeology Press.

Rostworowski, M. 2003. Peregrinaciones y procesiones rituales en los Andes. Journal de la Societé des Americanistes 89 (2): 97-123.
RowE, A. 1977. Warp-patterned weaves of the Andes. Washington DC: The textile Museum.

Rowe, A. 1995-1996. Inka weaving and costume. The Textile Museum Journal 34 y 35: 55-74.

Salomon, F. 2018. At the Mountain's Altar. Anthropology of Religion in an Andean Community. Londres-Nueva York: Routledge.

Santa Cruz Pachacuti Yamqui, J. 1993 [1613]. Relación de antigüedades deste reyno del Perú. Cuzco: IfEA-Centro Bartolomé de Las Casas.

Stobart, H. 2014. Lo recto y lo torcido. La música andina y la espiral de la descendencia. En Gente de carne y hueso. Las tramas del parentesco en los Andes. D. Arnold, Ed., pp. 581-604. La Paz: ILCA-CIASE.

¿Tomás? 2008 [1608]. Ritos y tradiciones de Huarochirí. Lima: IFEA-IE-Universidad de San Marcos.

Urton, G. 2004. Historia de un mito, Pacariqtambo y el origen de los Inkas. Cuzco: Centro de Estudios Regionales Bartolomé de Las Casas.

VItry, C. 2008. Los espacios rituales en las montañas donde los inkas practicaron sacrificios humanos. Paissangens culturais. Contrastes sul-americano, C. Terra \& A. Rubens, Eds., pp. 47-65. Río de Janeiro: Universidade do Rio de Janeiro.

Viveiros de CAstro, E. 2013. La mirada del jaguar. Introducción al perspectivismo amerindio. Entrevistas. Buenos Aires: Tinta Limón.

Zuidema, T. 1974. La imagen del sol y la huaca de Susurpuquio en el sistema astronómico de los incas en el Cuzco. Journal de la Societé des Americanistes 63: 199-230.

Zuidema, T. 1983. The lion in the city: royals symbols of transition in Cuzco. Journal of American Lore 9: 39-100. 